\title{
Devitrification Behavior in a Zinc Borosilicate Nuclear Waste Glass
}

by

R. P. Turcotte

J. W. Wald

March 1978

Prepared for the

U.S. Department of Energy

under Contract EY-76-C-06-1830

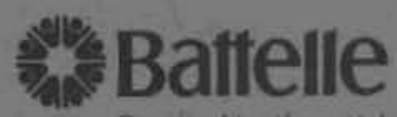

Pacitic Northwest Laboratories 


\title{
NOTICE
}

This report was prepared as an account of work sponsored by the United States Government. Neither the United States nor the Department of Energy, nor any of their employees, nor any of their contractors. subcontractors, or their employees, makes any warranty, express or implied, or assumes any legal liability or responsibility for the accuracy, completeness or usefulness of any information, apparatus, product or process disclosed, or represents that its use would not infringe privately owned rights.

The views, opinions and conclusions contained in this report are those of the contractor and do not necessarily represent those of the United States Government or the United States Department of Energy.

\author{
PACIFIC NORTHWIEST LABORATORY \\ operated by \\ BATTELLE \\ for the \\ UNITED STATES DEPARTMENT OF ENERGY \\ Under Contract EY-76-C-06-1830
}

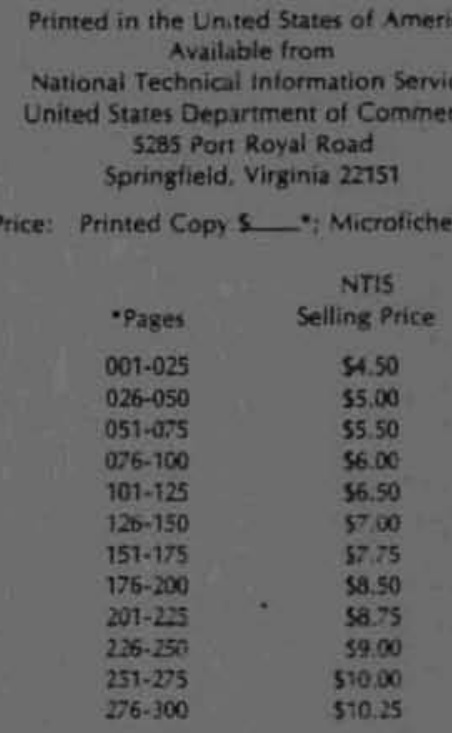


by

R. P. Turcotte

J. W. Wald

March 1978

\author{
Battelle \\ Pacific Northwest Laboratories \\ Richland, Washington 99352
}


8

. 


\section{SUMMARY}

This report describes experimental studies of thermally induced changes in a simulated nuclear waste glass. The intent of the studies was to define the composition and concentration of all phases formed over a broad range of time (up to one year) and temperature $\left(<1200^{\circ} \mathrm{C}\right.$ ) conditions. Although the results are specific to a single glass composition (72-68), enough data were obtained to demonstrate that quantitative understanding is possible. Crystallization rates and the approach to equilibrium are shown to follow expected trends based on theoretical/experimental studies of simple glasses.

The report is divided into a number of different sections and appendices that elaborate the experimental and theoretical aspects. Three major areas considered here summarize the most important results of the work.

\section{Equilibrium}

Depending on time and temperature, a steady-state condition is achieved in which a number of crystalline phases coexist with a glass phase which is partially depleted of some elements. Concentrations of the phases increase with decreasing temperature but usually reach only a fraction of their maximum theoretical concentration. Considering the major phase formed $\left(\mathrm{Zn}_{2} \mathrm{SiO}_{4}\right)$, this fractional concentration is about $10 \%$ at $900^{\circ} \mathrm{C}$ and $45 \%$ at $700^{\circ} \mathrm{C}$, when equilibrium is achieved. The major phases formed and their concentrations (wt\%) after one year $\left(600^{\circ} \mathrm{C}\right)$ are as follows: $\mathrm{Zn}_{2} \mathrm{SiO}_{4}(14),(\mathrm{Ca}, \mathrm{Sr}, \mathrm{Ba}) \mathrm{MoO}_{4}$ (6.9), (Ce, Zr, RE $\left.{ }^{3+}\right) 0_{2-x}(5),(\mathrm{Ca}, \mathrm{Zn})_{2}(\mathrm{La}, \mathrm{Nd}, \mathrm{Pr})_{8}\left(\mathrm{SiO}_{4}\right)_{6} \mathrm{O}_{2}(3), \mathrm{RuO}_{2}$ (1.9), $\mathrm{Pd}$ (0.8). Under these unfavorable time/temperature conditions, the glass is about one-third crystalline. Because of melt insolubles ( $\left.\mathrm{RuO}_{2}, \mathrm{Pd}\right)$ the most homogeneous glass will contain $23 \%$ crystalline phases.

\section{Kinetics}

Crystallization occurs at rates in agreement with those estimated from theory, based on a knowledge of the glass viscosity and an estimated heat 
of crystallization for the $\mathrm{Zn}_{2} \mathrm{SiO}_{4}$ phase. The times to reach steady-state concentrations range from a few hours at $900^{\circ} \mathrm{C}$ to $\sim 7$ year at $700^{\circ} \mathrm{C}$. No crysta 11 ization at $500^{\circ} \mathrm{C}$ was observed after one year. The crystal ingrowth rates follow a reasonable $1 / \mathrm{T}$ dependence for $\mathrm{Zn}_{2} \mathrm{SiO}_{4}$ and give an activation energy for the process of $\sim 40 \mathrm{kcal} / \mathrm{mole}$. Growth rates for the other phases are of the same order of magnitude as for $\mathrm{Zn}_{2} \mathrm{SiO}_{4}$.

Application to Waste Management

Other studies suggest devitrification increases leach rates in this glass by about a factor of 10 . In addition, the formation of large crystals of $\mathrm{Zn}_{2} \mathrm{SiO}_{4}$ causes extensive microcracking in the glass matrix. It must also be assumed that actinides may concentrate in phases where rare earth elements appear (apatite for example) and that subsequent radiation damage/ swelling will cause further microcracking. For these reasons it is desirable to maintain waste glasses in vitreous form. The results of the present work have therefore been used to evaluate processing/storage conditions needed to maintain a vitreous product. These conditions will likely be relaxed as improved glasses are developed but require only minor changes from processing conditions (faster cooling tc $\mathrm{T}<600^{\circ} \mathrm{C}$ ) and long-term storage conditions (centerline temperature $<375^{\circ} \mathrm{C}$ ) than now planned. It is shown further that crystallization over very long time periods $\left(10^{6}\right.$ years) will likely occur only if ambient temperatures exceed $\sim 225^{\circ} \mathrm{C}$ for the entire time period. 
CONTENTS

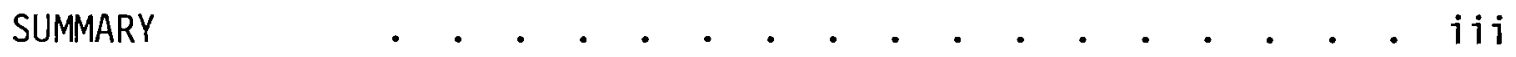

LIST OF FIGURES

LIST OF TABLES

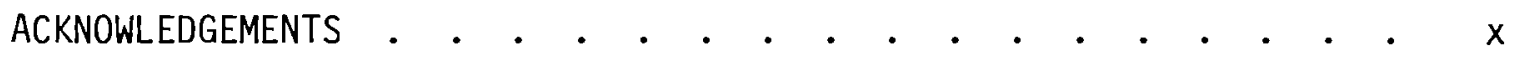

1. INTRODUCTION . . . . . . . . . . . . . . . . . . . 1

2. EXPERIMENTAL TECHNIQUES. . . . . . . . . . . . . .

MICROSCOPY •

X-RAY DIFFRACTION . . . . . . . . . . . . . . . . 3

SAMPLE PREPARATION • . . . . . . . . . . . . . . 4

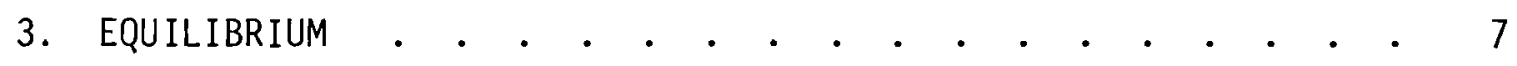

4. SHORT-TERM KINETIC STUDIES. . . . . . . . . . . . . 21

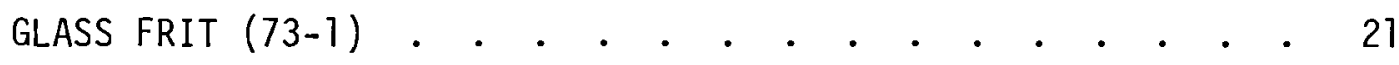

SIMULATED GLASS 72-68 . . . . . . . . . . . . . . 25

$\mathrm{Zn}_{2} \mathrm{SiO}_{4}$ Formation . . . . . . . . . . . . . 25

Other Phases . . . . . . . . . . . . . . . . 31

5. CRUCIBLE AND GLASS FORM EFFECTS . . . . . . . . . . . 35

SAMPLE MORPHOLOGY • • • • • • • • • • • • • • • • • 35

CRUCIBLE MATERIALS . . . . . . . . . . . . . . 36

CRUCIBLE LOAD . . . . . . . . . . . . . . . . 38

CALCINE/FRIT RATIO . . . . . . . . . . . . . . . . 38

6. APPLICATION TO WASTE DISPOSAL AND CONCLUSIONS . . . . . . 41

APPLICATION .

CONCLUSIONS . . . . . . . . . . . . . . . . . . 47

APPENDIX A - SUMMARY OF DEVITRIFICATION PRODUCTS. . . . . . . A- 
APPENDIX B - GLASS CRYSTALLIZATION - THEORETICAL CONSIDERATIONS. . B-1 APPENDIX C - QUANTITATIVE ANALYSES . . . . . . . . . . . C $\mathrm{C}-1$ 


\section{FIGURES}

1 SEM X-Ray Fluorescence Map of a Typical Vitreous 72-68 Glass • 8

2 SEM X-Ray Fluorescence Map of Devitrified 72-68 Glass . . . 9

3 Zinc Depletion in the Glass Matrix as a Function of Time at

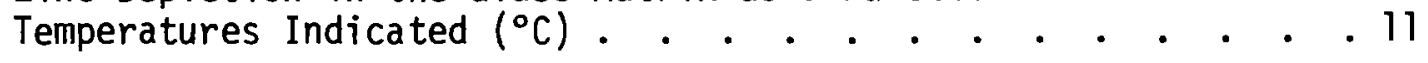

4 Molybdenum Depletion in the Glass Matrix as a Function of Time

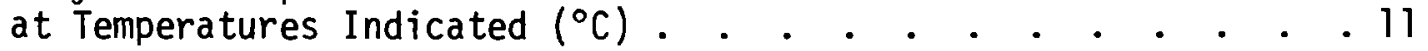

5 Strontium Depletion in the Glass Matrix as a Function of Time . at Temperatures Indicated $\left({ }^{\circ} \mathrm{C}\right)$. . . . . . . . . . 12

6 Typical X-Ray Diffraction Pattern for "As-Prepared" and Devitrified 72-68 Glass . . . . . . . . . . . . . . 13

7 Ingrowth of $\mathrm{Zn}_{2} \mathrm{SiO}_{4}$ as a function of Temperature for One Week of Annealing . . . . . . . . . . . . . . . 15

8 Ingrowth of $\mathrm{Zn} \mathrm{SiO}_{4}$ as a Function of Temperature for Annealing Times of One Week to One Year . . . . . . . 16

9 Ingrowth of $\mathrm{SrMOO}_{4}$ as a Function of Temperature for Annealing Times of One Week to One Year . . . . . . . . . . 16

10 X-Ray Diffraction Traces for Devitrified 72-68 Glass Illustrating the Ingrowth of Rare Earth-Apatite . . . . . . 18

11 Fractional Ingrowth versus $1 / \mathrm{T}$ for the Formation of $\mathrm{Zn}_{2} \mathrm{SiO}_{2}$ and $\mathrm{SrMOO}_{4}$

12 Kinetics of the Formation of $\mathrm{Zn}_{2} \mathrm{SiO}_{4}$ in 73-1 flass for $1200^{\circ} \mathrm{C}$ Buttons

13 Kinetics of the Formation of $\mathrm{Zn}_{2} \mathrm{SiO}_{4}$ in 73-1 Glass for $1000^{\circ} \mathrm{C}$ Remelt Samples

14 Time-Temperature Dependence for the Formation of $\mathrm{Zn}_{2} \mathrm{SiO}_{4}$ in 73-1 Glass.

15 Kinetics for the Formation of $\mathrm{Zn}_{2} \mathrm{SiO}_{4}$ in 72-68 Glass for $1200^{\circ} \mathrm{C}$ Buttons

16 Kinetics for the Formation of $\mathrm{Zn}_{2} \mathrm{SiO}_{4}$ in 72-68 Glass for $1000^{\circ} \mathrm{C}$ Reme 1 ts

17 Time-Temperature Dependence for the Formation of $\mathrm{Zn}_{2} \mathrm{SiO}_{4}$ 
18 Time-Temperature Dependence for the Formation of $\mathrm{Zn}_{2} \mathrm{SiO}_{4}$ in Glasses 73-1 and 72-68 for 50\% Fractional Transformation . . 29

19 SEM X-Ray Fluorescence Maps Illustrating the Effects of Nucleation Sites on the Formation of Crystalline Phases . . . 30

20 Ingrowth of $\mathrm{SrMoO}_{4}$ as a Function of Temperature at Short Times . 32

21 Ingrowth of $\mathrm{CeO}_{2}$ as a Function of Temperature at Short Times. . 33

22 Effects of Sample Morphology on the Formation of $\mathrm{Zn}_{2} \mathrm{SiO}_{4}$ in $72-68$ Glass

23 Effects of Total Waste Load on the Formation of $\mathrm{Zn}_{2} \mathrm{SiO}_{4}$ in 72-68 Glass. . . . . . . . . . . . . . . . 39

24 Expected Canister Thermal History as a Function of Time After Vitrification . . . . . . . . . . . . . . . 43

25 Extrapolation of Experimental Results to Long Times and Low Temperatures. . . . . . . . . . . . . . . 44

26 Time-Temperature Relationships to Retain a Vitreous Glass Product 


\section{$\underline{\text { TABLES }}$}

1 Borosilicate Glass (72-68) Composition . . . . . . . . . 5

2 Glass Frit (73-1) Composition . . . . . . . . . . . 5

3 Glass Matrix Composition Before and After Devitrification . . : 10

4 Crystalline Phases in Glass 72-68 . . . . . . . . . . . 14

5 Activation Energies for $25 \%, 50 \%$, and $75 \%$ Fractiona 1

Ingrowth of $\mathrm{Zn}_{2} \mathrm{SiO}_{4}$ in 73-1 Glass . . . . . . . . . . . . .25

6 Activation Energies for 25\%, 50\%, and 75\% Fractional

Ingrowth of $\mathrm{Zn}_{2} \mathrm{SiO}_{4}$ in 72-68 Glass . . . . . . . . . . . 28

7 Weight Percent Formation of the Major Crystalline Phases for

Buttons and Remelts Formed at $1200^{\circ} \mathrm{C}$ and Annealed at $850^{\circ} \mathrm{C}$

for $3.5 \mathrm{hr}$

8 Weight Percent Formation of the Major Crystalline Phases for Platinum, 304L Stainless Steel, and Alumina Crucibles Remelted at $1000^{\circ} \mathrm{C}$ and Annealed at $800^{\circ} \mathrm{C}$ for $16.5 \mathrm{hr}$. . . . 36

9 Weight Percent Formation of the Major Crystalline Phases at $2 \mathrm{~g}, 6 \mathrm{~g}$, and $12 \mathrm{~g}$ Loads in Standard $\mathrm{Al}_{2} \mathrm{O}_{3}$ Crucibles, Remelted at $1000^{\circ} \mathrm{C}$ and Annealed at $800^{\circ} \mathrm{C}$ for $16.5 \mathrm{hr}$. . . . . . . . . 38

10 Centerline Devitrification Estimates Based on Figure 24 . . . 45 


\section{ACKNOWLEDGEMENTS}

We are indebted to a number of people for assistance in various aspects of the work. J. H. Westsik prepared the glass and provided samples studied in Section 3. H. Tenny did the quantitative microprobe analyses. D. Parks provided optical micrographs. H. Kissinger generously allowed use of his $x$-ray diffraction equipment. 


\section{DEVITRIFICATION BEHAVIOR IN A \\ ZINC BOROSILICATE NUCLEAR WASTE GLASS}

R. P. Turcotte and J. W. Wald

\section{INTRODUCTION}

Glass is a promising solid form for the storage of high-level nuclear wastes, as is clear from the similarity of waste fixation development programs throughout the world. ${ }^{1,2)}$ It is generally recognized that the quality of the glass product will be affected by $i$ ts thermal and radiation history, which in turn will depend on the fission product loading, the age of the waste, the geometry of the waste form, and the thermal conductivity of the surroundings. Self-heating can result in centerline temperatures above $700^{\circ} \mathrm{C}$, where some devitrification is expected for low-temperature glasses. Processing procedures or potential accidents may also cause partial crystallization. Because these changes from a 'homogeneous' glass can affect dispersibility of the fission products, an assessment of thermal stability of waste glasses is necessary. The present document summarizes a detailed examination of anhydrous devitrification phenomena in a zinc borosilicate glass (PNL-72-68) containing 26 wt\% of a Purex-type waste calcine $(\mathrm{PW}-4 \mathrm{~b})$. Some of the results related to subsequent leaching behavior have been presented earlier. (3)

The intent of this study was to define the composition and concentration of all phases formed in the glass system as a function of temperature and time. Although the results are specific to a single glass composition (72-68) enough data were obtained to demonstrate in general that quantitative understanding is possible. Crystallization rates and the approach to equilibrium are shown to follow expected trends based on theoretical/experimental studies of simple glasses.

The report is divided into sections dealing with experimental techniques (Section 2), studies showing the approach to equilibrium (Section 3), short-term kinetic studies (Section 4), and crucible and glass form effects 
(Section 5). The potential impact of these studies on waste vitrification and storage are discussed in Section 6. Appendices consider in some detail characteristics of the devitrification products (Appendix $A$ ), the pertinent crystal growth theory (Appendix B), and experimental aspects of the quantitative analyses undertaken (Appendix $C$ ). 


\section{EXPERIMENTAL TECHNIQUES}

This study is part of a comprehensive characterization effort described by Mendel. (4) Section 8.4 of that report discusses the general experimental approach. The glasses were examined by $x$-ray diffraction, optical microscopy, and scanning electron microscopy (SEM), which included $x$-ray fluorescence mapping. Quantitative microprobe analyses were made for some elements, using the vitreous glass or pure compounds as standards.

\section{MICROSCOPY}

Metallographic examination of polished samples was made at magnifications generally less than 500x. The greater detail of microstructure obtained on the metallograph aided in subsequent microprobe and SEM examinations. Several electron microscope systems were used, in part for comparative purposes and also because both wavelength and energy dispersive fluorescence capabilities were available. Most of the quantitative fluorescence work was performed on an electron microprobe employing a wavelength detection system. As illustrated in Appendix $C$, our gelieral experience has been that comparable analyses can be obtained, regardless of whether energy dispersive or wavelength dispersive systems are used. Because of the large number of elements present, the fluorescence peaks often overlap so that the higher resolution of the wave length detection systems provides some potential for better quality $x$-ray mapping and quantitative analyses. An SEM equipped for energydispersive fluorescence analysis, on the other hand, provides more detailed microstructural images and a shorter analysis time.

\section{X-RAY DIFFRACTION}

Diffraction analysis was the primary analytical tool used because of the comparatively easy sample preparation, known reproducibility $( \pm 5-10 \%)$, and the fact that concentrations of phases are determined directly rather than indirectly. X-ray work was performed on a Phillips/Norelco diffractometer equipped with a solid-state detection and recording system. 
Copper radiation ( $\lambda=1.54178 \AA$ ) was used throughout the work. Powder samples were prepared by standard procedures. As shown in Appendix C, concentrations to below 1 wt\% can be determined with reasonable accuracy, provided appropriate standards are used and peak area determinations are utilized rather than peak heights.

\section{SAMPLE PREPARATION}

The borosilicate glass composition is given in Table 1. The parent frit glass (73-1) has the composition given in Table 2. The original glass was prepared by blending calcine $(P W-4 b-6)$ from a low-temperature spray calciner (the calcine is $x$-ray amorphous) and glass frit (73-1) and then melting in a stainless steel (304L) crucible for $2 \mathrm{hr}$ at $1000^{\circ} \mathrm{C}$. The glass was quenched to room temperature, crushed, and individual crucibles of $\sim 20 \mathrm{~g}$ of glass were reheated to $1000^{\circ} \mathrm{C}$ before cooling directly to the devitrification temperature. For devitrification temperatures of $600^{\circ} \mathrm{C}$ or higher, alumina crucibles were used. At lower temperatures, stainless steel was used. Examination of these samples is discussed primarily in Section 3 of this report.

For short-term studies, a large number of small (3-g) samples were prepared from the original melt. One set of samples was 'remelted' in platinum crucibles at $1000^{\circ} \mathrm{C}$ and air cooled to room temperature. A second set of samples was cast as buttons from a $1200^{\circ} \mathrm{C}$ melt by pouring into a high-density graphite mold at $\sim 350^{\circ} \mathrm{C}$ and slow cooling to room temperature. Both sets of samples were subjected to similar devitrification temperatures for times generally less than $100 \mathrm{hr}$. Results obtained with these samples are discussed in Sections 4 and 5 . 
TABLE 1. Borosilicate Glass (72-68) Composition

\begin{tabular}{|c|c|c|c|c|c|}
\hline Oxide & $\begin{array}{c}\text { Composition, } \\
\text { wt\% } \\
\end{array}$ & Oxide & $\begin{array}{l}\text { Composition, } \\
\text { wt\% } \\
\end{array}$ & Oxide & $\begin{array}{c}\text { Composition, } \\
\text { wt\% }\end{array}$ \\
\hline $\mathrm{SiO}_{2}$ & 27.31 & NiO & 0.66 & $\mathrm{TeO}_{2}$ & 0.46 \\
\hline $\mathrm{B}_{2} \mathrm{O}_{3}$ & 11.15 & $\mathrm{P}_{2} \mathrm{O}_{5}$ & 0.42 & $\mathrm{Cs}_{2} \mathrm{O}$ & 1.82 \\
\hline $\mathrm{Na}_{2} \mathrm{O}$ & 4.06 & $\mathrm{Rb}_{2} \mathrm{O}$ & 0.22 & $\mathrm{La}_{2} \mathrm{O}_{3}$ & 0.93 \\
\hline $\mathrm{K}_{2} \mathrm{O}$ & 4.06 & $\mathrm{Y}_{2} \mathrm{O}_{3}$ & 0.38 & $\mathrm{CeO}_{2}$ & 2.11 \\
\hline $\mathrm{ZnO}$ & 21.34 & $\mathrm{ZrO}_{2}$ & 3.13 & $\operatorname{Pr}_{6}{ }^{0} 11$ & 0.94 \\
\hline $\mathrm{CaO}$ & 1.47 & $\mathrm{MoO}_{3}$ & 4.03 & $\mathrm{Nd}_{2} \mathrm{O}_{3}$ & 2.95 \\
\hline $\mathrm{MgO}$ & 1.47 & $\mathrm{RuO}_{2}$ & 1.88 & $\mathrm{Sm}_{2} \mathrm{O}_{3}$ & 0.58 \\
\hline Sro & 2.15 & $\mathrm{Rh}_{2} \mathrm{O}_{3}$ & 0.30 & $\mathrm{Eu}_{2} \mathrm{O}_{3}$ & 0.13 \\
\hline $\mathrm{BaO}$ & 2.47 & $\mathrm{Pd} 0$ & 0.94 & $\mathrm{Gd}_{2} \mathrm{O}_{3}$ & 0.09 \\
\hline $\mathrm{Fe}_{2} \mathrm{O}_{3}$ & 0.95 & $\mathrm{Ag}_{2} \mathrm{O}$ & 0.06 & $\mathrm{UO}_{2}$ & 1.26 \\
\hline $\mathrm{Cr}_{2} \mathrm{O}_{3}$ & 0.22 & $\mathrm{Cd} 0$ & 0.06 & & \\
\hline
\end{tabular}

TABLE 2. Glass Frit (73-1) Composition

$\begin{array}{lc}\text { Oxide } & \text { Composition, wt\% } \\ \mathrm{SiO}_{2} & 37.0 \\ \mathrm{~B}_{2} \mathrm{O}_{3} & 15.1 \\ \mathrm{Na}_{2} \mathrm{O} & 5.5 \\ \mathrm{~K}_{2} \mathrm{O} & 5.5 \\ \mathrm{ZnO} & 28.9 \\ \mathrm{CaO} & 2.0 \\ \mathrm{MgO} & 2.0 \\ \mathrm{SrO} & 2.0 \\ \mathrm{BaO} & 2.0\end{array}$


r. 


\section{EQUILIBRIUM}

Analyses are given here for a series of devitrified glass samples also examined for leaching behavior. $(3,5)$ The times and temperatures for devitrification covered the ranges 1 day to 1 year and $300^{\circ}$ to $900^{\circ} \mathrm{C}$, respectively. $X$-ray maps of typical vitreous and devitrified samples are shown in Figures 1 and 2. For the vitreous glass, some phase separation can be seen for palladium, ruthenium, cerium, and iron (also nickel and chrome). For the devitrified glass, in addition to the above elements, zinc and molybdenum (also associated calcium, barium, and strontium) separate as major devitrification products. Glass matrix compositions as estimated by microprobe analys is are given in Table 3 for these two samples. It can be inferred from the table that analysis for the rare earths, in particular, is not easily accomplished with scatter arising from difficulty in correcting for overlap of the fluorescence peaks. After devitrification, decreasing glassphase concentrations clearly occur for strontium, molybdenum, and zinc. other apparent concentration changes do not appear to be significant since a realistic assessment of reproducibility in this work gives errors of about $\pm 0.3 w t \%$.

The microprobe examinations of the glass matrix for $\mathrm{Zn}$, Mo, and $\mathrm{Sr}$, as a function of time, are summarized respectively in Figures 3,4 , and 5 , for samples heat treated over a two-month period. In all of the figures the data are plotted for each of the isotherms with each data point actually representing at least three independent measurements of concentration in the glass matrix. The values for zinc are the result of two separate determinations done several weeks apart on the same glass samples. Significant changes with annealing time occur in the case of zinc where at the lower temperatures some time is required to reach maximum depletions, and strontium, which at 700 and $750^{\circ} \mathrm{C}$ shows decreased depletion at 60 days. For molybdenum there may be a small trend to increasing depletion with time at 600 and $700^{\circ} \mathrm{C}$. The molybdate actually formed in this glass is a solid solution of calcium-strontium-barium, and with time, the molar ratio of these constituents changes, as discussed later. 


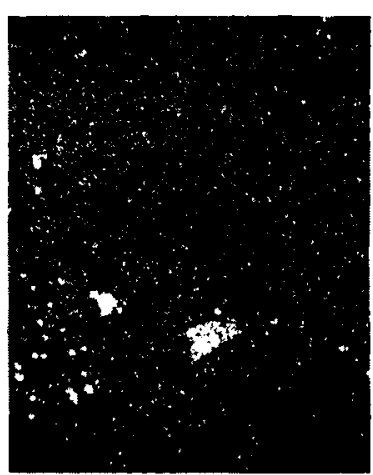

Pd

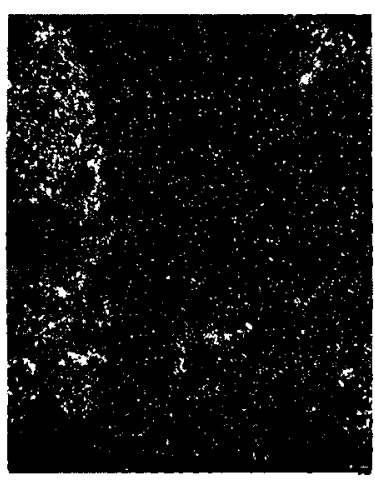

$\mathrm{Ru}$

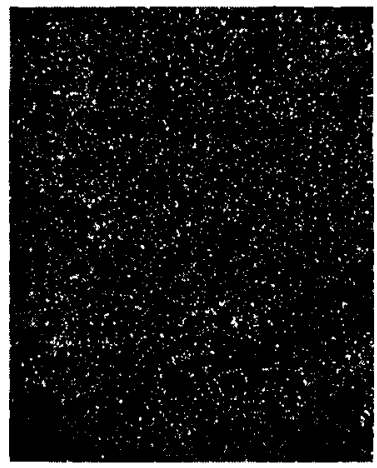

$\mathrm{Ce}$

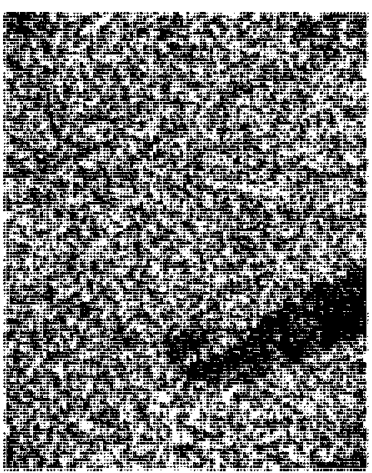

K

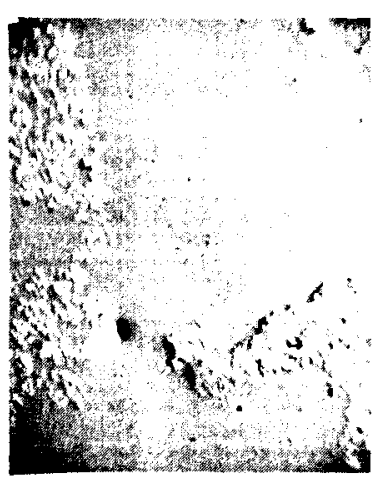

Probe Image

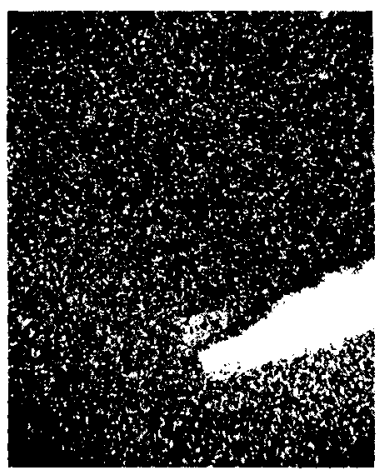

$\mathrm{Fe}$

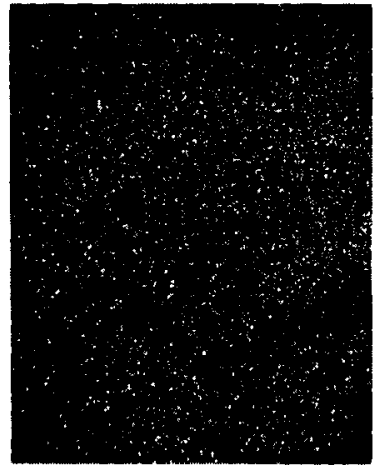

U

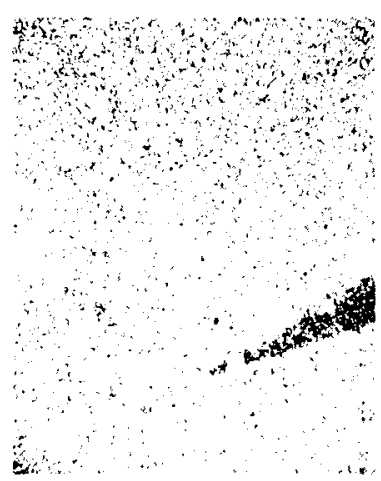

$\mathrm{Zn}$

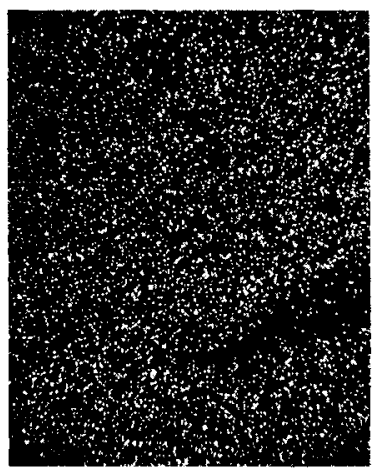

Mo

$250 \mu \mathrm{m}$

VI TREOUS $1000^{\circ} \mathrm{C}$ MELT

FIGURE 1. SEM X-Ray Fluorescence Map of a Typical Vitreous 72-68 GTass 


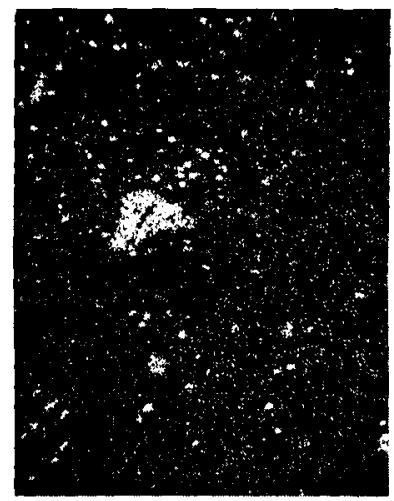

$\mathrm{Pd}$

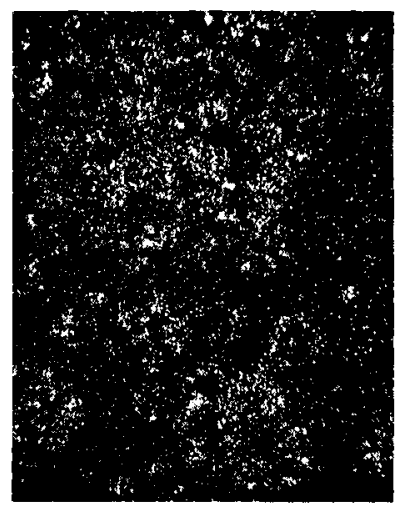

$\mathrm{Ru}$

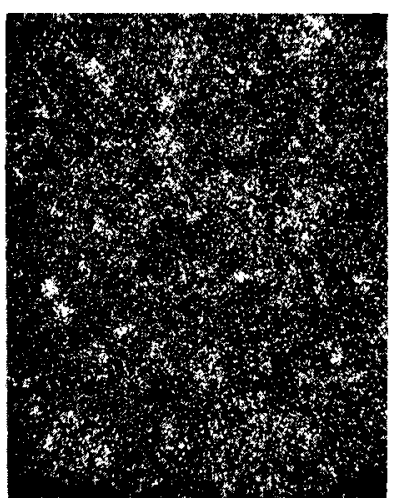

Ce

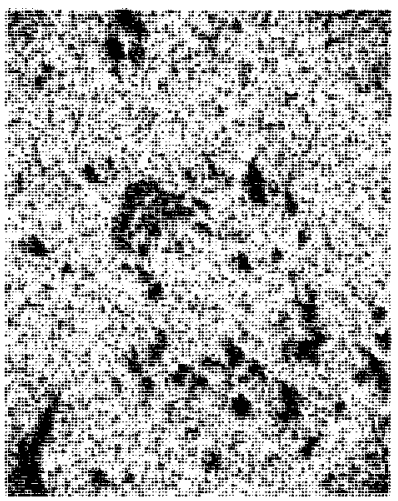

$\mathrm{K}$

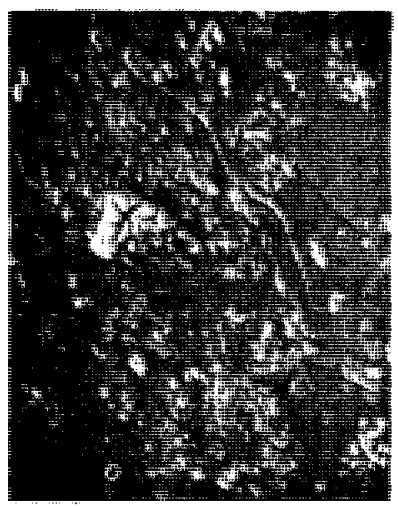

Probe Image

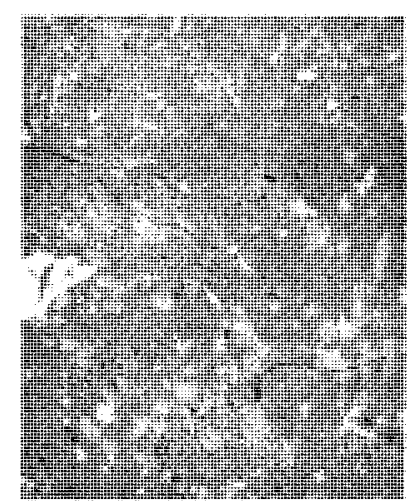

Optical Image

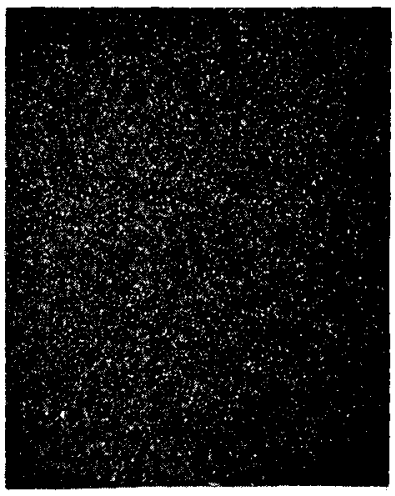

U

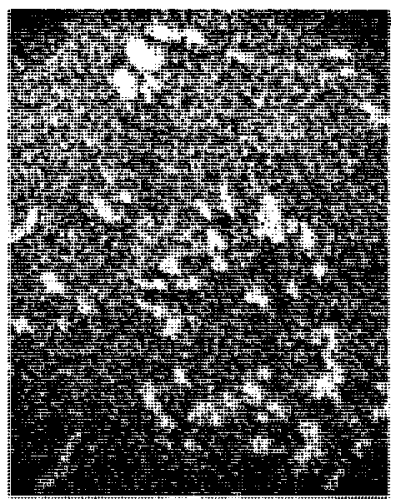

$\mathrm{Zn}$

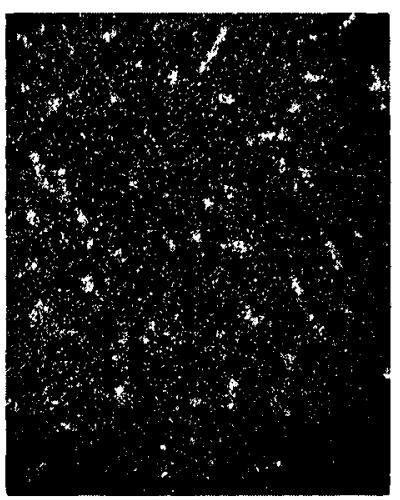

Mo DEVITRIFIED $800^{\circ} \mathrm{C}, 1$ DAY

FIGURE 2. SEM X-Ray FTuorescence Map of Devitrified 72-68 Glass 
IABLE 3. Glass Matrix Composition Before and After Devitrification

\begin{tabular}{|c|c|c|c|c|}
\hline \multirow[b]{2}{*}{ Element } & \multirow[b]{2}{*}{$\begin{array}{r}\text { Moles } / \mathrm{g} \text { of Glass } \\
\times 10^{4} \\
\end{array}$} & \multirow[b]{2}{*}{$\begin{array}{l}\text { Concentration } \\
\text { as Prepared, wt\% }\end{array}$} & \multicolumn{2}{|c|}{ Microprobe Analyses, $(a)$ wt\% } \\
\hline & & & $\begin{array}{l}\text { Vitreous } \\
1000^{\circ} \mathrm{C}-4 \mathrm{hr} \\
\end{array}$ & $\begin{array}{l}\text { Devitrified } \\
800^{\circ} \mathrm{C}-1 \text { day } \\
\end{array}$ \\
\hline $\mathrm{Na}$ & 13.05 & 3.00 & 3.8 & 3.7 \\
\hline$K$ & 8.59 & 3.36 & 3.6 & 3.7 \\
\hline $\mathrm{Rb}$ & 2.34 & 0.20 & --- & -.- \\
\hline Cs & 1.29 & 1.72 & 2.6 & 2.6 \\
\hline $\mathrm{Mg}$ & 3.66 & 0.89 & 1.0 & 0.9 \\
\hline $\mathrm{Ca}$ & 2.62 & 1.05 & 1.0 & 1.0 \\
\hline $\mathrm{Sr}$ & 2.07 & 1.81 & 2.0 & 1.5 \\
\hline $\mathrm{Ba}$ & 1.60 & 2.20 & 1.8 & 1.7 \\
\hline $\mathrm{Zr}$ & 2.53 & 2.31 & 1.6 & 1.8 \\
\hline $\mathrm{Cr}$ & 0.33 & 0.17 & 0.2 & 0.1 \\
\hline Mo & 2.79 & 2.68 & 1.9 & 1.2 \\
\hline $\mathrm{Fe}$ & 1.18 & 0.66 & 0.6 & 0.7 \\
\hline $\mathrm{Ru}$ & 1.41 & 1.43 & 0.1 & 0.1 \\
\hline Co & 0.23 & 0.14 & --- & --- \\
\hline $\mathrm{Rh}$ & 0.23 & 0.24 & 0.2 & 0.2 \\
\hline $\mathrm{Ni}$ & 0.89 & 0.52 & 0.3 & 0.2 \\
\hline$P d$ & 0.77 & 0.82 & 0.3 & 0.2 \\
\hline $\mathrm{Ag}$ & 0.06 & 0.06 & 0.2 & 0.2 \\
\hline$Z n$ & 26.15 & 17.1 & 16.9 & 11.6 \\
\hline $\mathrm{Cd}$ & 0.04 & 0.05 & --- & -- \\
\hline Si & 45.34 & 12.74 & 16.9 & 17.9 \\
\hline P & 0.58 & 0.18 & 0.2 & 0.2 \\
\hline Te & 0.29 & 0.37 & 0.3 & 0.3 \\
\hline $\mathrm{Ca}$ & 0.57 & 0.79 & 1.1 & 0.6 \\
\hline $\mathrm{Ce}$ & 1.22 & 1.71 & 1.1 & 1.6 \\
\hline $\mathrm{Pr}$ & 0.52 & 0.73 & 0.2 & 0.9 \\
\hline $\mathrm{Nd}$ & 1.75 & 2.52 & 2.1 & 3.5 \\
\hline Sm & 0.33 & 0.50 & 0.7 & 0.7 \\
\hline Gd & 0.05 & 0.08 & 0.5 & 0.3 \\
\hline$U$ & 0.47 & 1.11 & 1.3 & 1.1 \\
\hline
\end{tabular}

(a) Mean of three determinations 


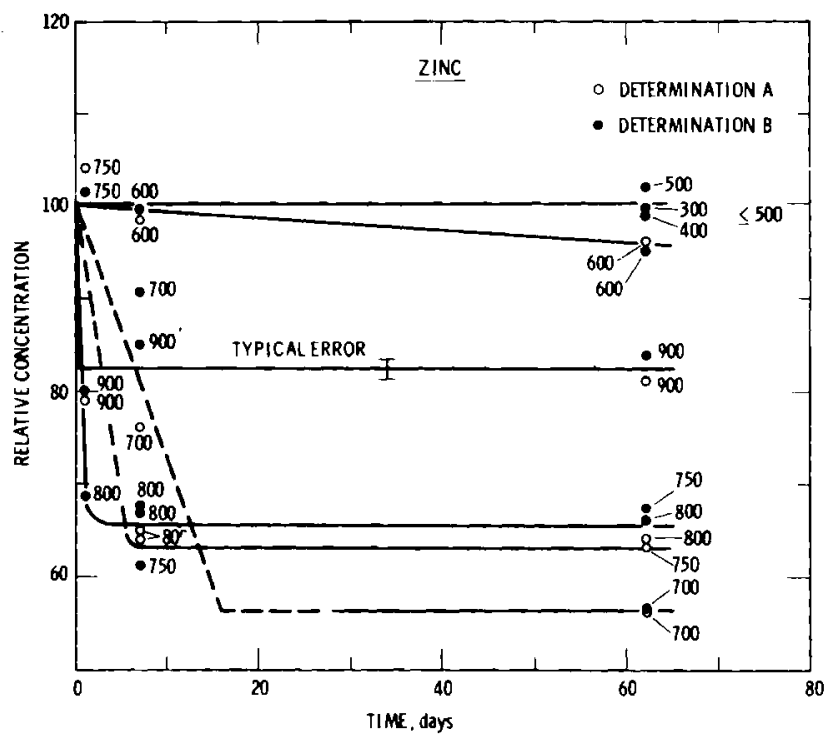

FIGURE 3. Zinc Depletion in the Glass Matrix as a Function of Time at Temperatures Indicated $\left({ }^{\circ} \mathrm{C}\right)$

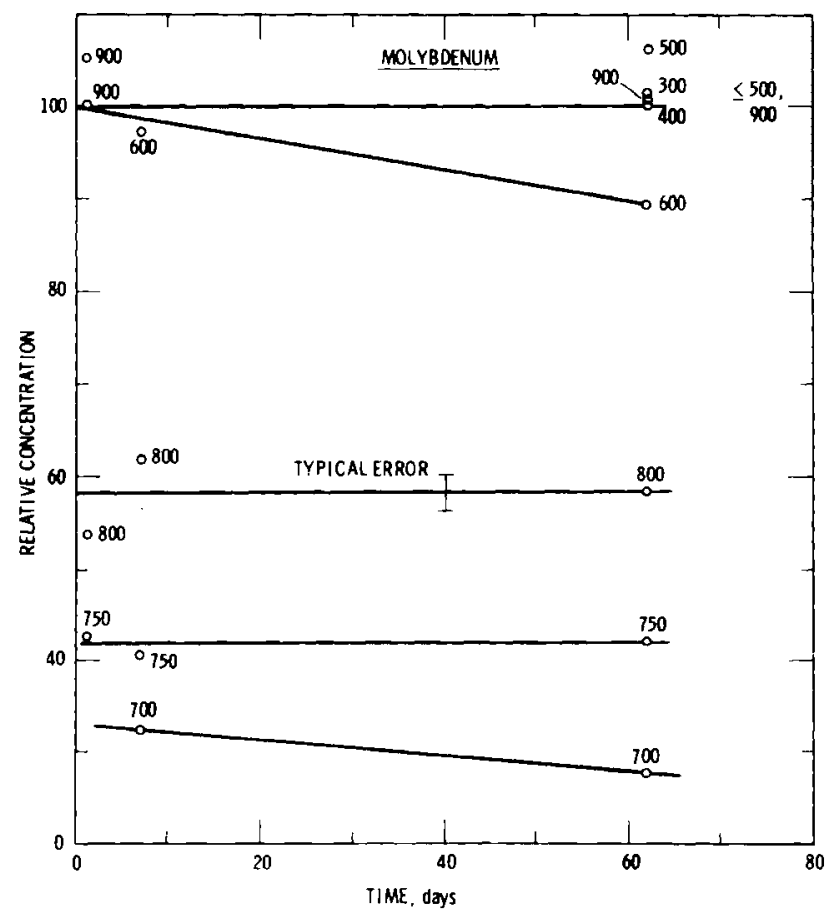

FIGURE 4. Molybdenum Depletion in the Glass Matrix as a Function of Time at Temperatures Indicated $\left({ }^{\circ} \mathrm{C}\right)$ 


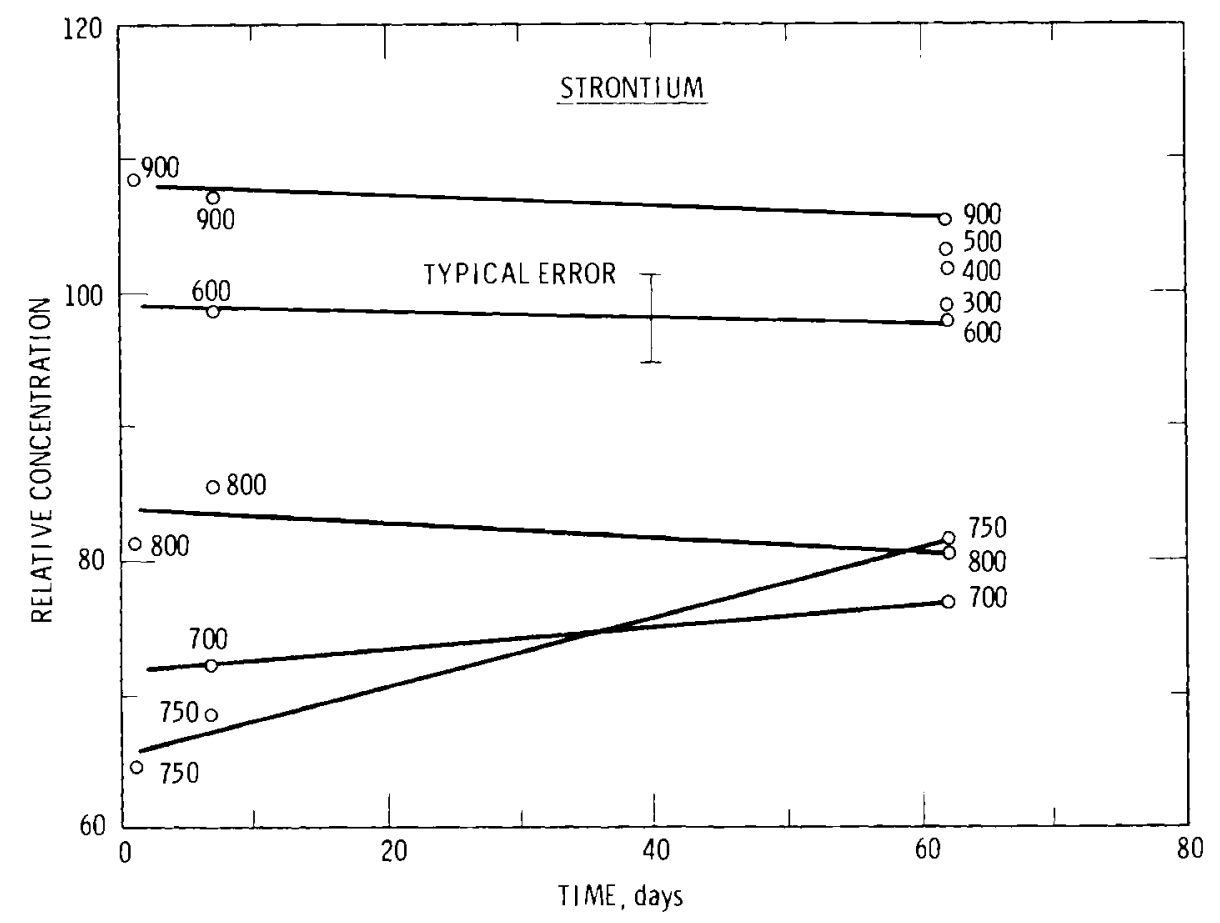

FIGURE 5. Strontium Depletion in the Glass Matrix as a Function of Time at Temperatures Indicated $\left({ }^{\circ} \mathrm{C}\right)$

The $x$-ray diffraction traces for the as-prepared glass and for glasses heated two months at $700^{\circ} \mathrm{C}$ are shown in Figure 6 . It should be noted that the diffraction intensities have not been normalized and are actually very weak for the as-prepared glass; the palladium (200) reflection, for example, is usually not even detectable. With an understanding of the phase stoichiometries as determined by microprobe analysis and by comparison of the unindexed $x$-ray patterns to standard patterns given in the ASTM $x$-ray powder data files, it was possible to identify virtually all of the diffraction peaks obtained in either as-prepared or devitrified glasses. Although the diffraction lines in Figure 6 are indexed as arising from pure compounds, some solid solutions are actually formed as would be expected in such a complex glass. The actual phases observed are summarized in Table 4. Changes with time beyond two months annealing are not large 

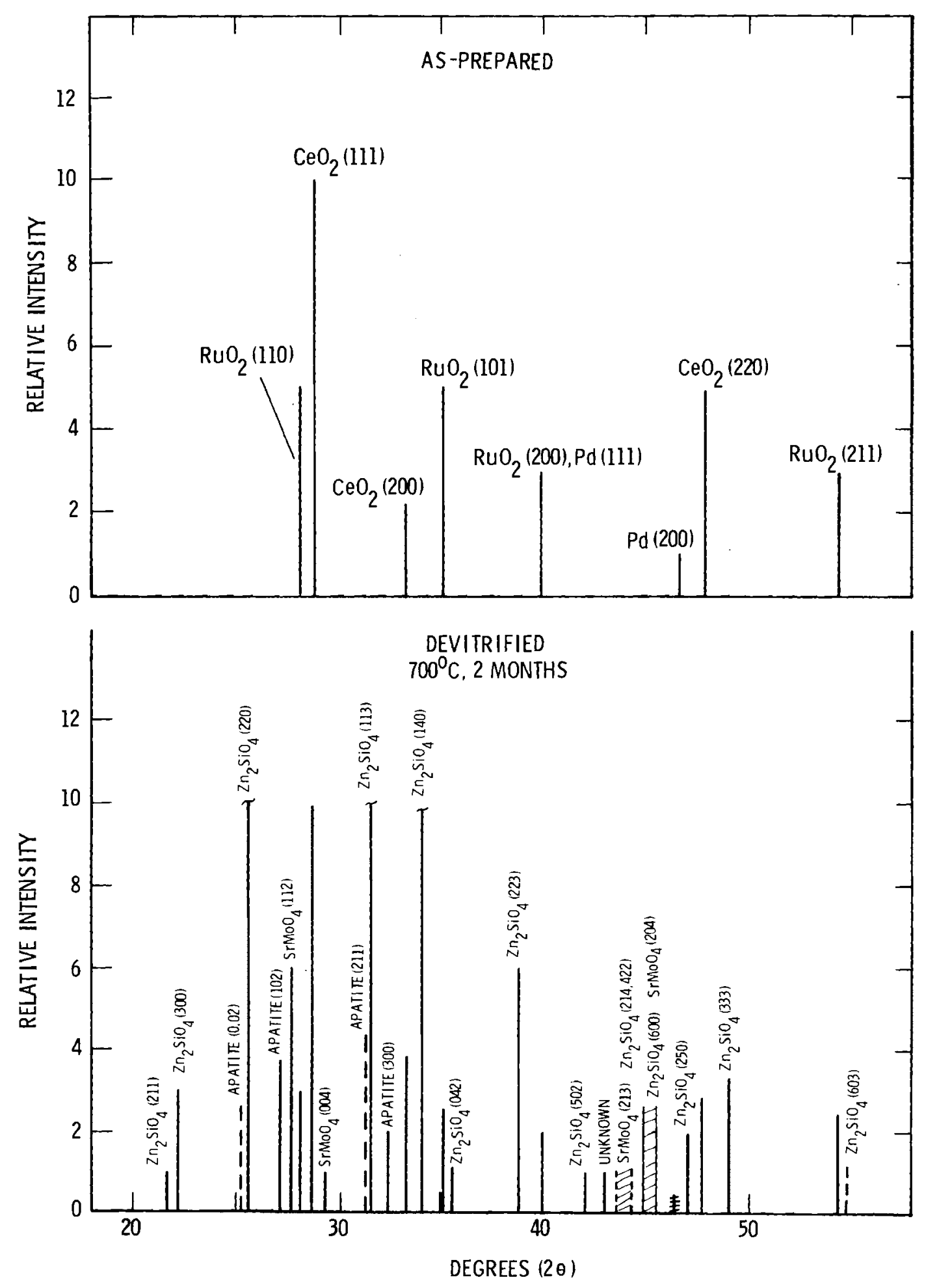

FIGURE 6. Typical X-Ray Diffraction Pattern for "As-Prepared" and Devitrified 72-68 Glass 
TABLE 4. Crystalline Phases in Glass 72-68

\begin{tabular}{|c|c|c|c|c|c|c|}
\hline $\begin{array}{l}\text { wt: } \\
\text { Melt }\end{array}$ & $\begin{array}{l}\text { in } \\
\left(1000^{\circ} \mathrm{C}\right)\end{array}$ & $\begin{array}{l}\text { wt\% after } \\
1 \text { Year }\left(600^{\circ} \mathrm{C}\right) \\
\end{array}$ & Structure & $\begin{array}{l}\text { Lattice } \\
\text { Constants } \\
\end{array}$ & $\begin{array}{l}\text { Maximum Crystal } \\
\text { Size, } \mu \mathrm{m} \\
\end{array}$ & $\begin{array}{l}\text { Liquidous } \mathrm{Tem}^{\mathrm{Tem}} \\
\text { peratures, }{ }^{\circ} \mathrm{C}\end{array}$ \\
\hline $\mathrm{Zn}_{2} \mathrm{SiO}_{4}$ & 0 & 14 & Hexagonal & $\begin{array}{l}a_{0}=13.97 \AA \\
c_{0}^{0}=9.30\end{array}$ & $500 \times 100$ & 980 \\
\hline$(\mathrm{Ca}, \underline{\mathrm{Sr}}, \mathrm{Ba}) \mathrm{MOO}_{4}$ & 0 & 6.0 & Tetragona 1 & $\begin{array}{l}a_{0}=5.38 \\
c_{0}=12.03\end{array}$ & $100 \times 2$ & 900 \\
\hline$\left(C e, z r, R E^{3+}\right) 0_{2-x}$ & 5 & 5.0 & Cubic & $a_{0}=5.39$ & 5 & $\sim 1200$ \\
\hline $\mathrm{RuO}_{2}$ & 1.4 & 1.4 & Tetragonal & $\begin{array}{l}a_{0}=5.40 \\
c_{0}=3.10\end{array}$ & 1 & Insoluble \\
\hline $\mathrm{Ca}_{2}\left(\mathrm{RE}^{3+}\right)_{8}\left(\mathrm{SiO}_{4}\right)_{6} \mathrm{O}_{2}$ & 0 & 3 & Hexagonal & $\begin{array}{l}a_{0}=9.54 \\
c_{0}=7.16\end{array}$ & $500 \times 100$ & 2800 \\
\hline Pd & 1.0 & 1.0 & Cubic & $a_{0}=3.90$ & 10 & Insoluble \\
\hline$(\mathrm{Zr}, \mathrm{Ni})(\mathrm{Fe}, \mathrm{Cr})_{2} \mathrm{O}_{4}$ & Trace & Trace & Cubic & & 50 & -- \\
\hline
\end{tabular}

at any temperature. Additional comments relating to the stoichiometry and thermal stability of these phases appear in Appendix A.

Figure 7 compares the quantitative analyses (wt\%) for zinc silicate as determined by microprobe analyses and x-ray diffraction (XRD). The agreement is best in the temperature range where the crystals are reasonably large. At 600 and $700^{\circ} \mathrm{C}$, depending on the time of annealing, the crystals are in the micron range or less and are quite uniformly distributed throughout the glass matrix. When this occurs, it is difficult to select a glass phase region which will not count some of the zinc silicate crystals as being part of that matrix. The microprobe in this case gives results that suggest very little zinc has been depleted from the glass matrix when in fact a rather large concentration of very small crystals exists. Because of this complication, the XRD method is a more reliable tool for quantitative analyses in these systems, since it gives positive evidence of the various phases forming rather than the complementary function. Furthermore, the method's accuracy increases with smaller crystal size because self-absorption effects are minimized. 


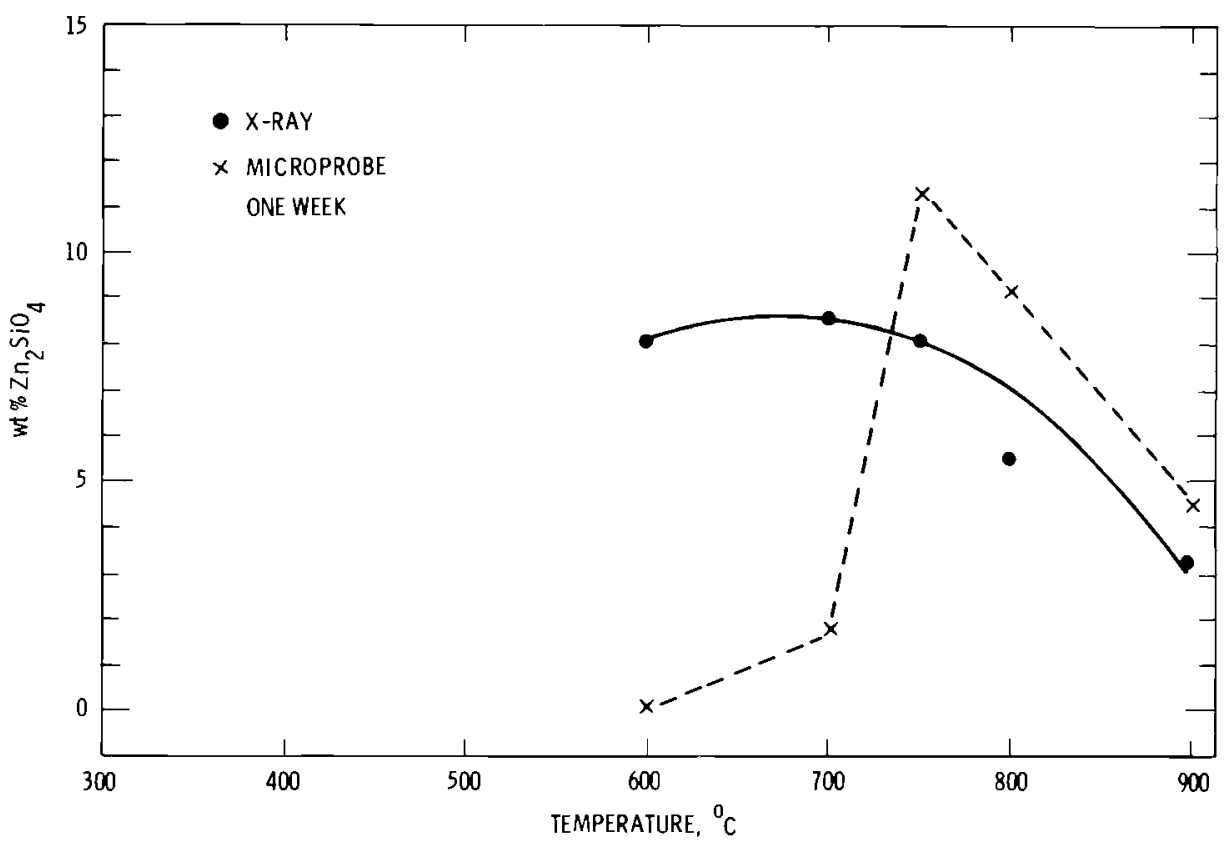

FIGURE 7. Ingrowth of $\mathrm{Zn}_{2} \mathrm{SiO}_{4}$ as a Function of Temperature for One Week of Annealing

The complete sets of XRD data are given in Figures 8 and 9 for $\mathrm{Zn}_{2} \mathrm{SiO}_{4}$ and $\left(\mathrm{Ca}_{0.25} \mathrm{Sr}_{0.50} \mathrm{Ba}_{0.25}\right) \mathrm{MoO}_{4}$, respectively. For $\mathrm{Zn}_{2} \mathrm{SiO}_{4}$ in Figure 8 , the straight line extending from $13 \mathrm{wt} \%$ at $700^{\circ} \mathrm{C}$ to $0 \mathrm{wt} \%$ at $980^{\circ} \mathrm{C}$ is assumed to represent equilibrium. The deviations from this curve are a regular function of time although at $800^{\circ} \mathrm{C}$ and above, equilibrium is achieved in one day or 1ess. For the molybdate phase (Figure 9), the trends are not so straightforward, since concentrations at $700^{\circ} \mathrm{C}$ and above are higher after one day and one week than they are after the two month and one year anneals. In order to verify this difference, some additional microprobe work was done on the three $700^{\circ} \mathrm{C}$ samples. The total Mo concentration was determined in two different areas of each sample at 100X magnification and found to be (in wt\%) $1.7 \pm 0.2$ ( 1 week), $1.9 \pm 0.2$ (2 months) and $1.8 \pm 0.2$ (1 year). These values compare well with the $1.9 \mathrm{wt} \%$ value determined earlier for the vitreous glass (see Tabile 2). It is concluded that the lower molybdate crystalline phase concentration is not due to volatilization of molybdenum from the long-time annealed samples. X-ray mapping does suggest a molybdate 


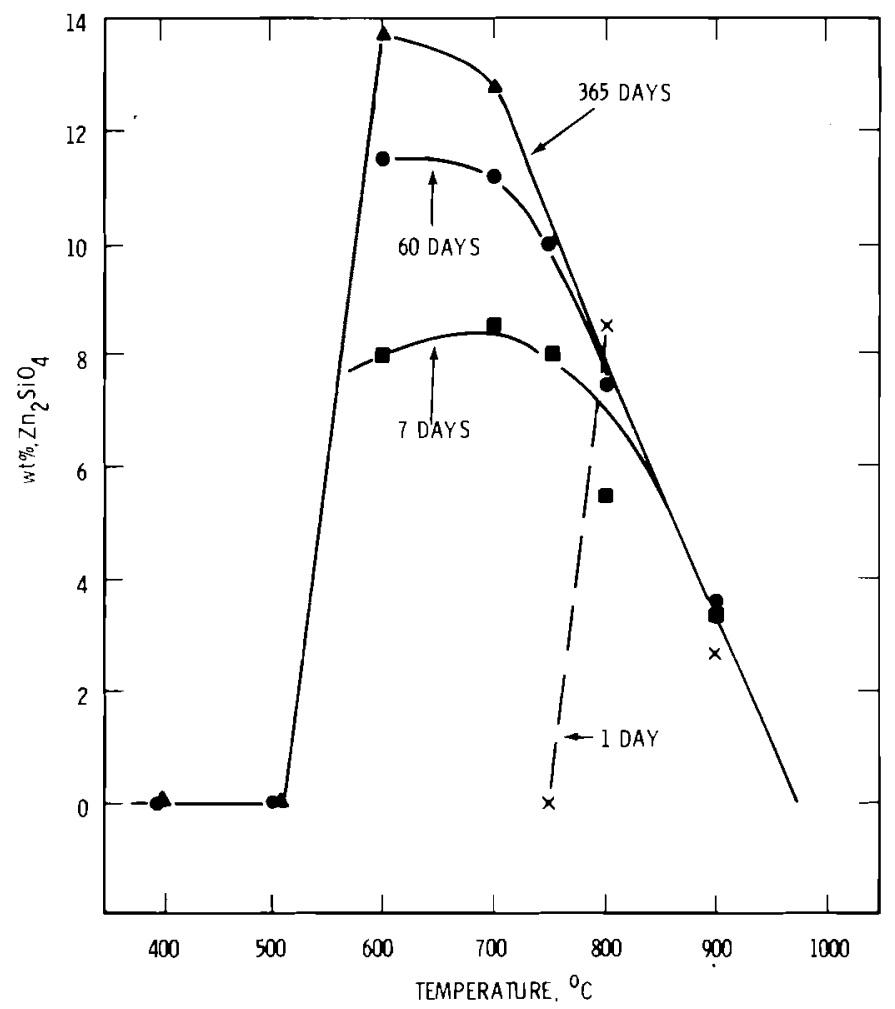

FIGURE 8. Ingrowth of $\mathrm{Zn}_{2} \mathrm{SiO}_{4}$ as a Function of Temperature for Annealing Times of One Week to One Year

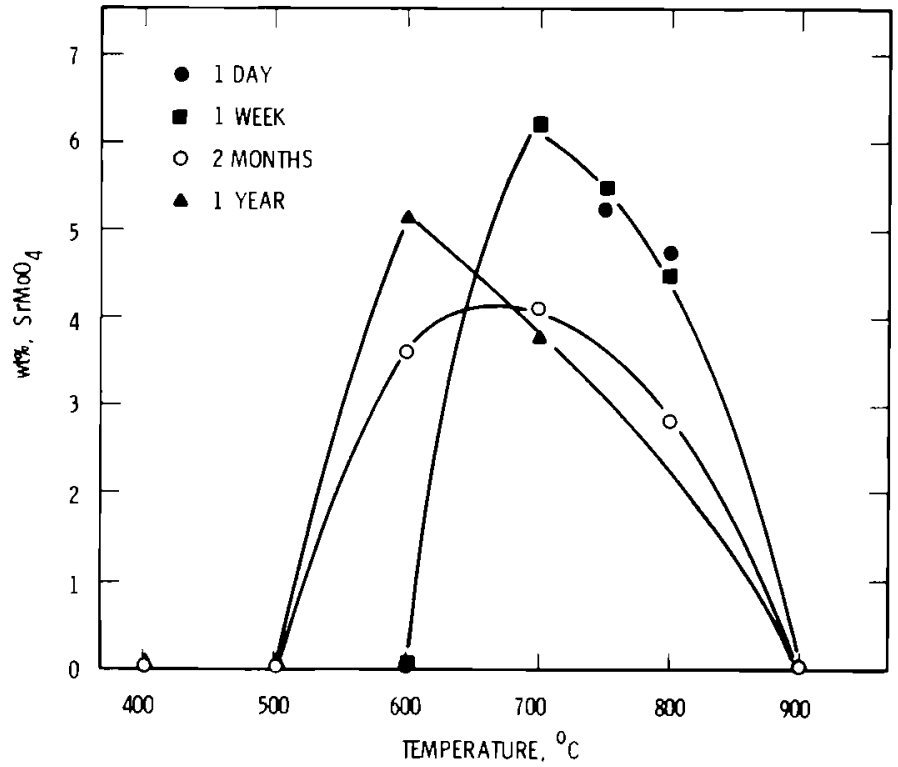

FIGURE 9. Ingrowth of $\mathrm{SrMoO}_{4}$ as a Function of Temperature for Annealing Times of One Week to One Year 
phase concentration 1 week $>2$ months $\simeq 1$ year for the three samples, but because the crystals of all phases are so small (and numerous) at this temperature, a reliable estimate of Mo concentration in the glass matrix could not be established.

The change can be explained by the late formation of a calciumcontaining rare-earth apatite phase. Actual slow-scan x-ray diffraction traces are shown in Figure 10 for samples maintained at $700^{\circ} \mathrm{C}$ for one week, 2 months, and one year. They clearly suggest the transfer of calcium from the molybdate to the apatite phase. After one year, there appears to be two molybdate phases, both having diffraction peak positions at lower $2 \theta$ values than the original compound. Hence the change is to larger unit cell dimensions as the larger $\mathrm{Sr}$ and $\mathrm{Ba}$ ions become dominant: $\left(r_{\mathrm{Ca}^{2+}}=0.99 \AA, r_{\mathrm{Sr}^{2+}}=1.13 \AA, r_{\mathrm{Ba}^{2+}}=1.35 \AA\right)$. It is interesting to note that while the compositions of several other solid solution phases (Fluorite- $\mathrm{MO}_{2}$ and Spinel $\mathrm{M}_{3} \mathrm{O}_{4}$ ) change slightly, depending on annealing temperature and time, no other examples of large concentration changes due to cation exchange between crystalline phases were observed.

The form of the "equilibrium" curves for the silicate and molybdate phases agrees well with expectations based on the theory discussed in Appendix B. As shown there, a plot of fractional crystallization (in terms of fractional glass phase concentrations versus $1 / T$ ) should give a straight line for both compounds of slope $\sim \Delta H^{\circ} / 2 R$, where $\Delta H^{\circ}$ is the heat of crystallization. The equilibrium data, so plotted in Figure 11, do in fact yield excellent straight lines with enthalpy changes corresponding to

$$
\begin{aligned}
& \Delta \mathrm{H}^{\circ} \mathrm{Zn}_{2} \mathrm{SiO}_{4} \simeq-13 \mathrm{kcal} / \mathrm{mole} \\
& \Delta \mathrm{H}^{\circ}(\mathrm{Ca}, \mathrm{Sr}, \mathrm{Ba}) \mathrm{MoO}_{4} \simeq-53 \mathrm{kcal} / \mathrm{mole}
\end{aligned}
$$



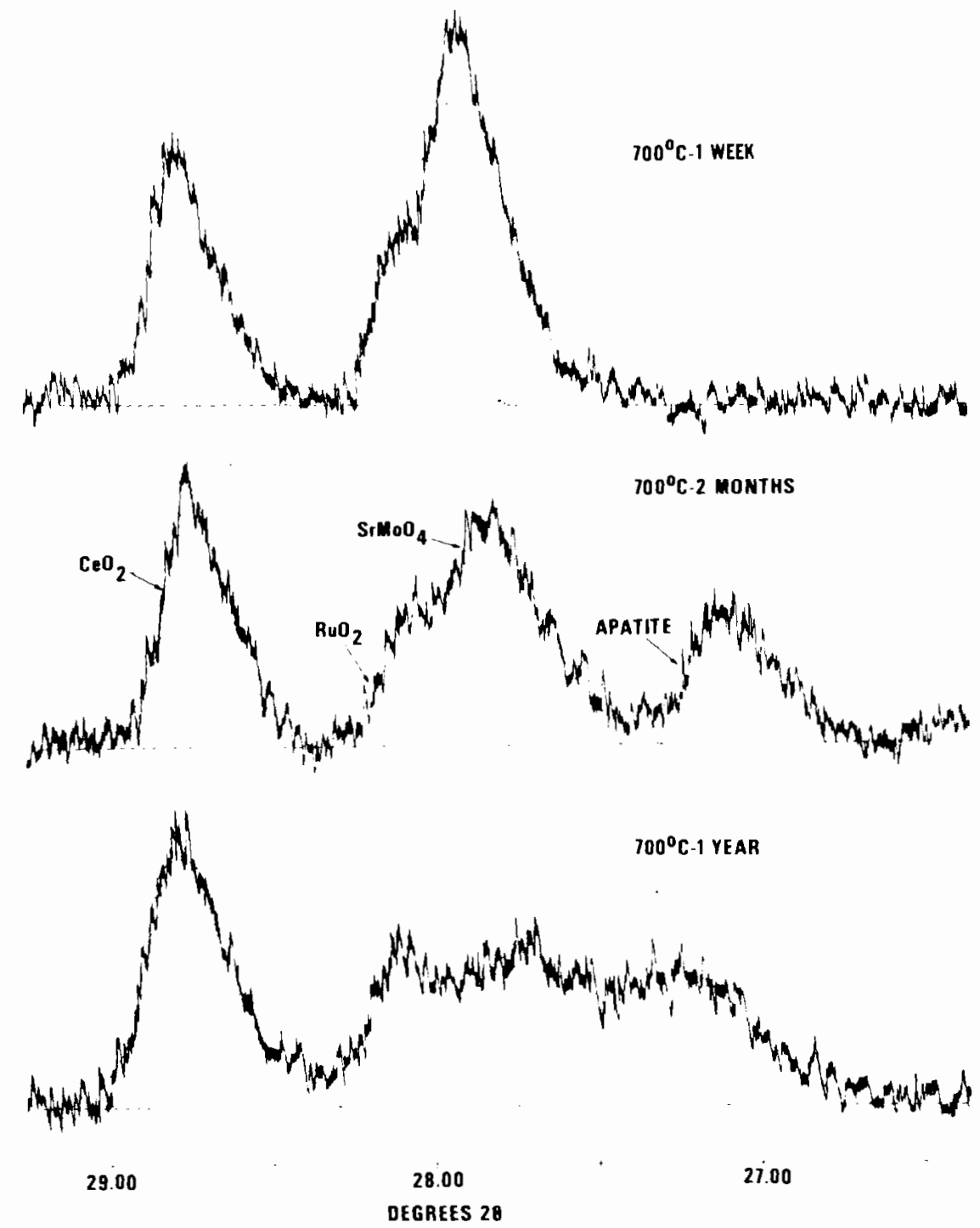

FIGURE 10. X-Ray Diffraction Traces for Devitrified 72-68 Glass Illustrating the Ingrowth of Rare Earth-Apatite

These are clearly rough estimates of the real values but even so are in the expected direction since the silicate value is low compared to the molybdate value, reflecting mechanisms relating to melting (low $\Delta H$ ) and diffusion, respectively. For the other phases that form, equilibrium data have not been generated. We do know that fluorite phase $\mathrm{MO}_{2-x}$ precipitates quickly and to completion within a narrow temperature span; hence it will have a large $\Delta H^{\circ}$ value. 


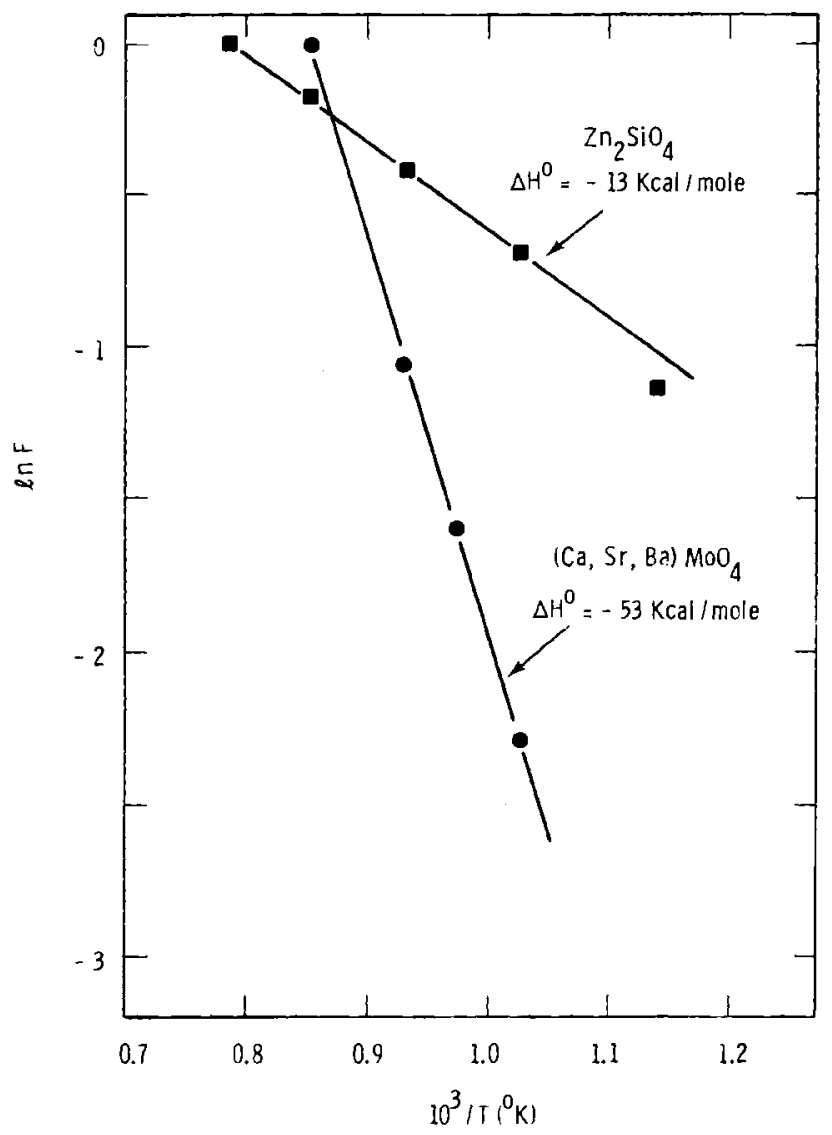

FIGURE 11. Fractional Ingrowth versus $1 / T$ for the Formation of $\mathrm{Zn}_{2} \mathrm{SiO}_{4}$ and $\mathrm{SrMoO}_{4}$ 
,

. 


\section{SHORT-TERM KINETIC STUDIES}

Formation of crystalline species occurs because of a small gain in free energy at rates ultimately limited by ion diffusion at low temperatures and by chemical equilibria at high temperatures. Isothermal annealing experiments were conducted in the present study to generate fractional crystallization data as a function of time. Quenched samples were examined by slow-scan $x$-ray diffraction, generally yielding sigmoidal ingrowth curves for yield ( $w$ t\%) plotted versus log time. By considering a series of isothermal ingrowth curves at constant fraction ingrowth, the Arrhenius temperature dependence was defined for several different glasses and sample morphologies.

Because waste glasses are so complex, some work was done on the ninecomponent glass frit (73-1) for comparative purposes. Only one crystalline product forms in this glass $\left(\mathrm{Zn}_{2} \mathrm{SiO}_{4}\right)$, which is also the major phase in devitrified glass (72-68). The comparison therefore provides an opportunity to establish the importance of minor elemental species (i.e., fission products) on major crystallization phenomena. The two glasses are considered separately in the following discussion.

\section{GLASS FRIT (73-1)}

Two melting temperatures were employed in this study $\left(1200^{\circ} \mathrm{C}\right.$ and $\left.1000^{\circ} \mathrm{C}\right)$ and the two sample morphologies used were buttons and remelted powder, respectively. Platinum crucibles were used throughout for all the kinetic samples. Figures 12 and 13 illustrate $\mathrm{Zn}_{2} \mathrm{SiO}_{4}$ ingrowth as a function of time for the $1200^{\circ} \mathrm{C}$ buttons and $1000^{\circ} \mathrm{C}$ remelt samples, respectively. As expected, the devitrification rate increases with temperature and the maximum concentration attained is higher at lower temperatures. The form of the curves is somewhat unusual in that a maximum concentration is reached at intermediate times. The effect is most pronounced in the button experiments (Figure 12) where the decrease at long times is several wt\%. The trends with temperature are less regular for the $1000^{\circ} \mathrm{C}$ remelt than for the 

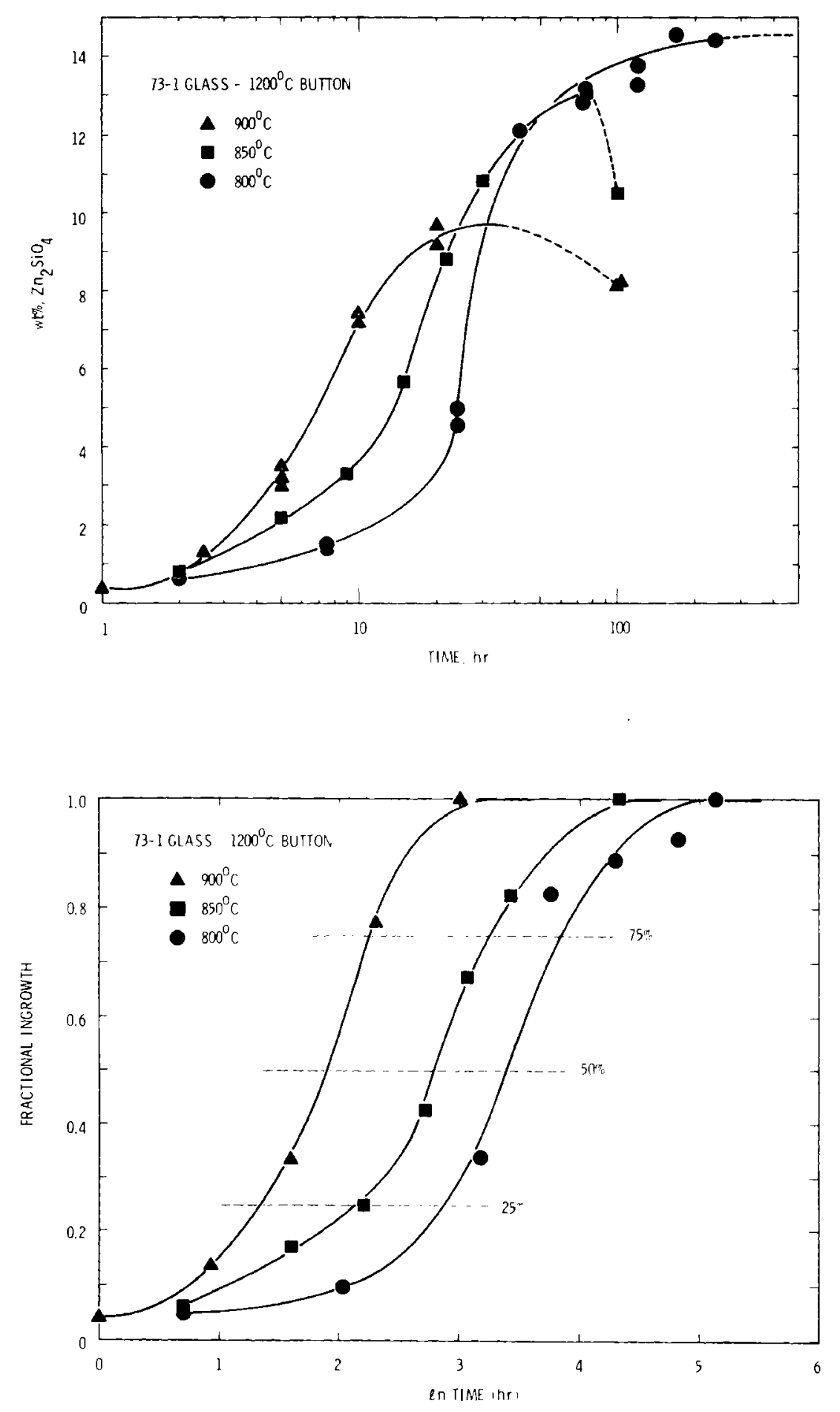

FIGURE 12. Kinetics of the Formation of $\mathrm{Zn}_{2} \mathrm{SiO}_{4}$ in $73-1$ Glass for $1200^{\circ} \mathrm{C}$ Buttons 

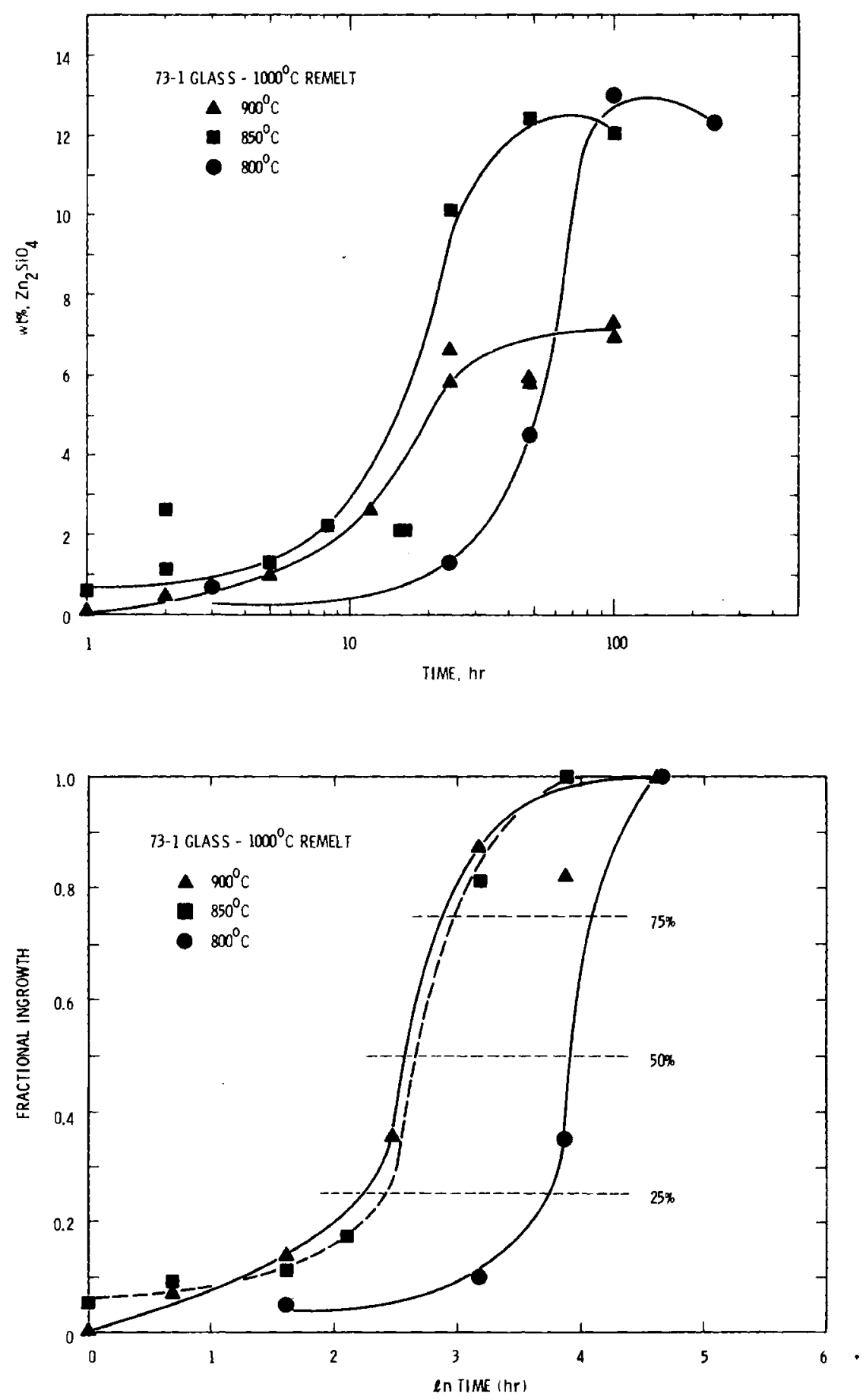
FIGURE 13. Kinetics of the Formation of $\mathrm{Zn}_{2} \mathrm{SiO}_{4}$ in 73-1 Glass for $1000^{\circ} \mathrm{C}$
Remelt Samples 
$1200^{\circ} \mathrm{C}$ buttons, since data at $900^{\circ} \mathrm{C}$ are bracketed by the two lower-temperature curves. Figure 14 shows the results at 25, 50, and $75 \%$ fractional ingrowth plotted as in $t(h r)$ versus $1 / T\left({ }^{\circ} \mathrm{K}\right)$. Activation energies determined from the slopes are given in Table 5 and appear to be independent of ingrowth fraction. It should be noted that although the two glass melts give the same activation energy, the rates are higher for the buttons than for the $1000^{\circ} \mathrm{C}$ remelt.

It can be seen that the induction period for the start of crystal1ization and the growth rate are temperature dependent. For $225 \%$ ingrowth of $\mathrm{Zn}_{2} \mathrm{SiO}_{4}$, the reaction times required at 900,850 , and $800^{\circ} \mathrm{C}$ are 3,8 , and 15 hours, respectively, while additional times required to reach $\sim 75 \%$ ingrowth are 7,24 , and 45 hours.
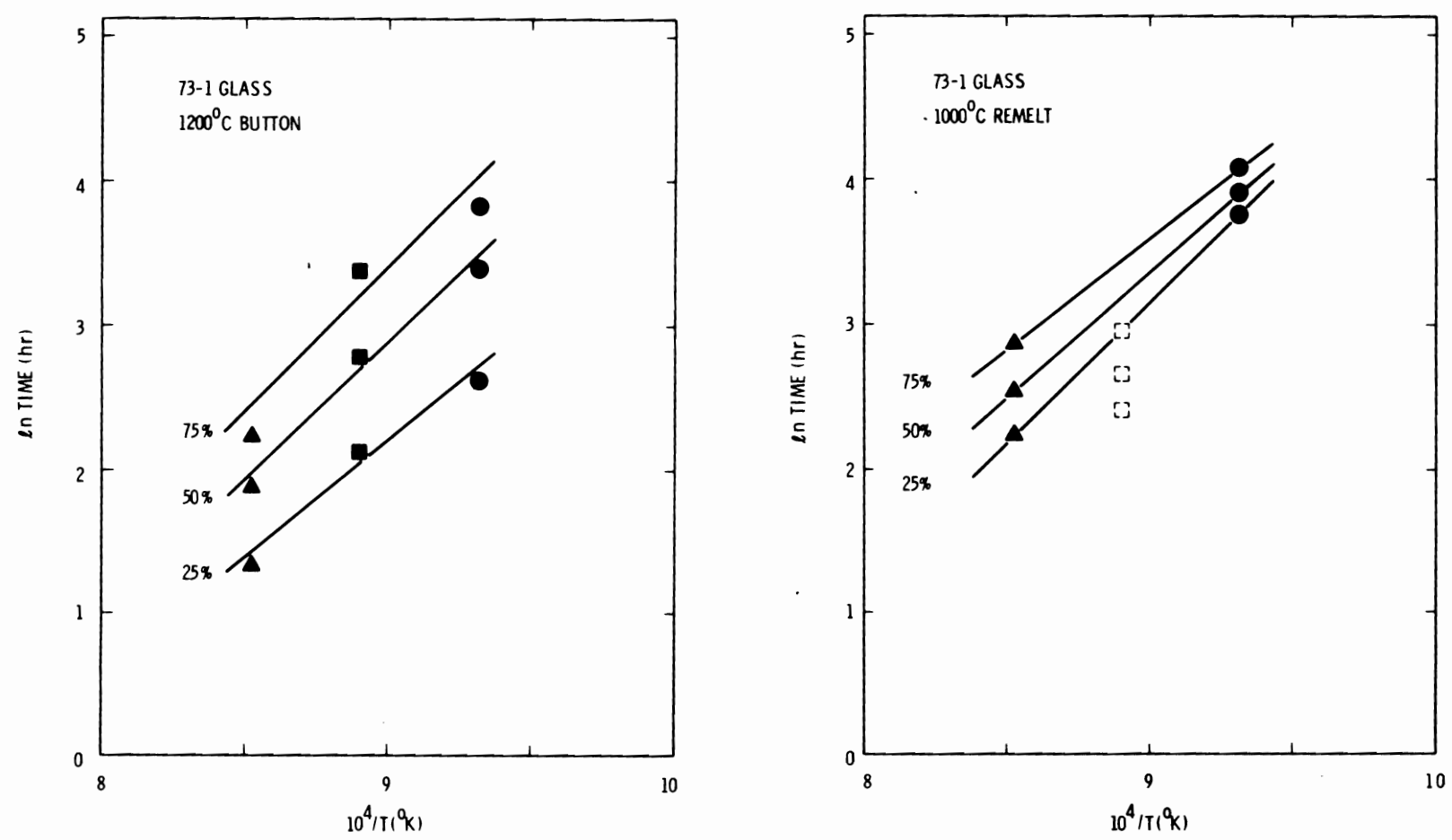

FIGURE 14. Time-Temperature Dependence for the Formation of $\mathrm{Zn}_{2} \mathrm{SiO}_{4}$ in 73-1 Glass 
TABLE 5. Activation Energies for 25\%, 50\%, and $75 \%$

Fractional Ingrowth of $\mathrm{Zn}_{2} \mathrm{SiO}_{4}$ in 73-1 Glass

$\begin{array}{llr} & 1200^{\circ} \mathrm{C} \text { Buttons } & \frac{1000^{\circ} \mathrm{C} \text { Remelts }}{38 \mathrm{kcal}} \\ 25 \% & 39 \mathrm{kcal} & 34 \mathrm{kcal} \\ 50 \% & 38 \mathrm{kcal} & 30 \mathrm{kcal}\end{array}$

Average $=$

$38 \mathrm{kcal}$

34 kcal

\section{SIMULATED GLASS $72-68$}

In glass $72-68$, there were three crystalline phases of interest in the short-term kinetic studies: $\mathrm{Zn}_{2} \mathrm{SiO}_{4}, \mathrm{SrMoO}_{4}$, and $\mathrm{CeO}_{2}$. Activation energies were estimated for the formation of $\mathrm{Zn}_{2} \mathrm{SiO}_{4}$ as in the preceeding section, but not for the formation of $\mathrm{SrMoO}_{4}$ or $\mathrm{CeO}_{2}$ because the reaction rates were too rapid for meaningful measurement in the same temperature/time range appropriate for studying $\mathrm{Zn}_{2} \mathrm{SiO}_{4} . \mathrm{RuO}_{2}$ and $\mathrm{Pd}$ are present in as-prepared glasses and do not change in concentration at any annealing temperature used.

\section{$\underline{\mathrm{Zn}}_{2} \underline{\mathrm{SiO}}_{4}$ Formation}

Figures 15 and 16 illustrate the ingrowth of $\mathrm{Zn}_{2} \mathrm{SiO}_{4}$ as a function of time for $1200^{\circ} \mathrm{C}$ buttons and $1000^{\circ} \mathrm{C}$ remelts, respectively. The general form of the ingrowth curves is similar to those obtained for the (73-1) frit. Scatter is lower and the temperature dependence is more regular for the complex waste glass, but absolute differences between the $1200^{\circ} \mathrm{C}$ glass and the $1000^{\circ} \mathrm{C}$ remelt are greater. The in $\mathrm{t}$ versus $1 / \mathrm{T}$ plots in Figure 17 and the activation energies determined from the slopes of the lines (Table 6) clearly show large differences. 

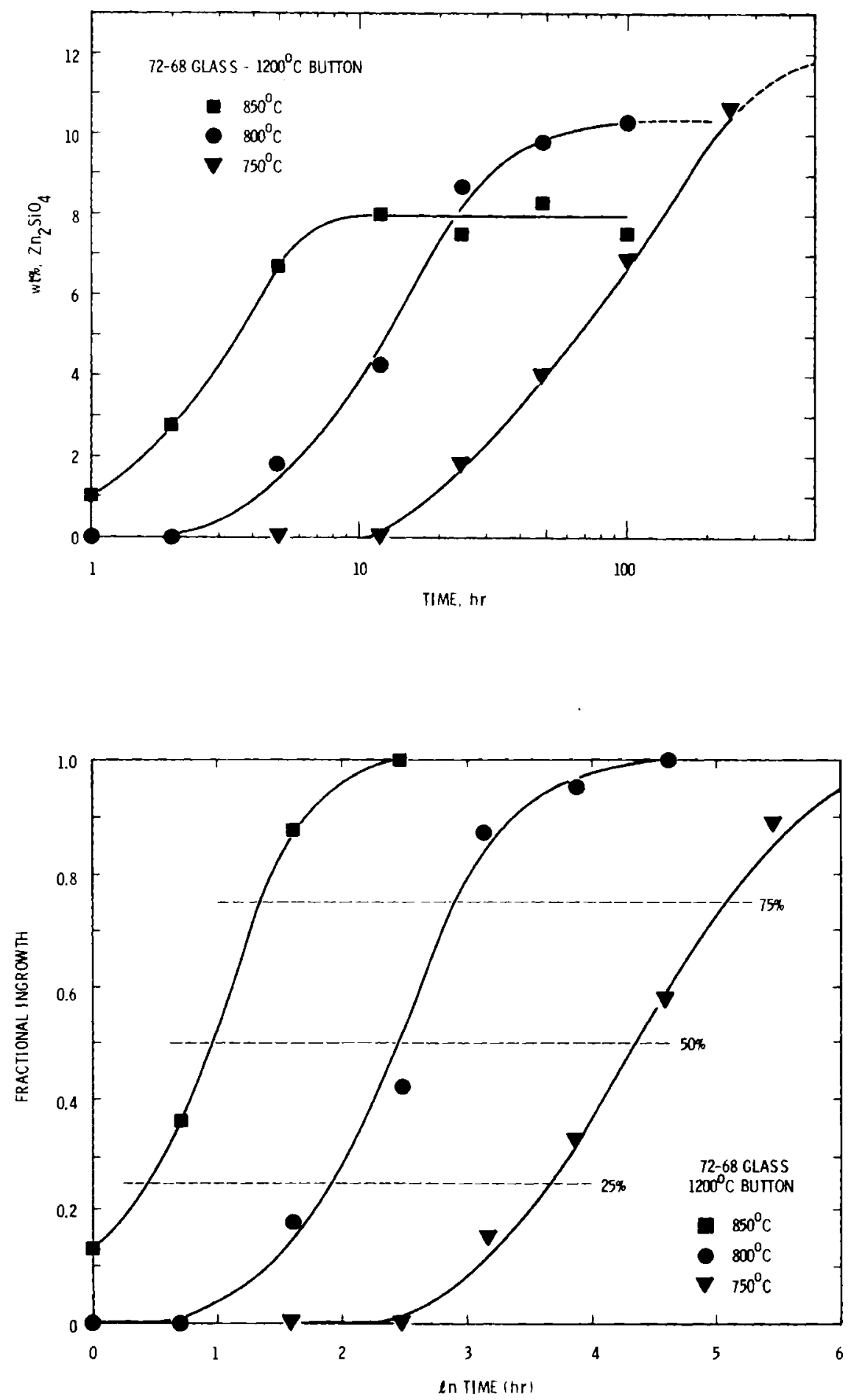

FIGURE 15. Kinetics for the Formation of $\mathrm{Zn}_{2} \mathrm{SiO}_{4}$ in $72-68$ Glass for $1200^{\circ} \mathrm{C}$ Buttons 

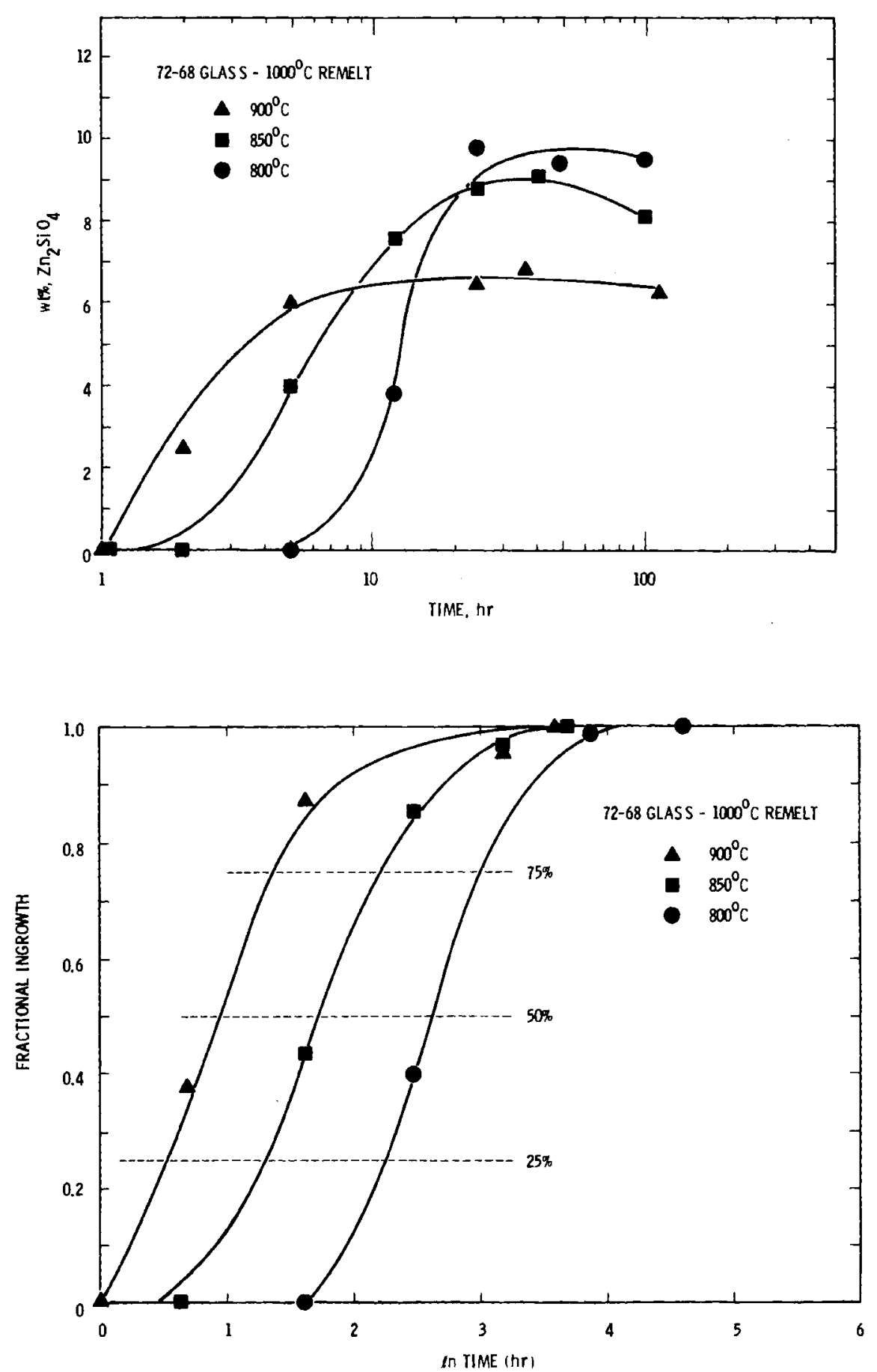
FIGURE 16. Kinetics for the Formation of $\mathrm{Zn}_{2} \mathrm{SiO}_{4}$ in $72-68$ Glass for
$1000^{\circ} \mathrm{C}$ Remelts 
IABLE 6. Activation Energies for 25\%, 50\%, and $75 \%$

Fractional Ingrowth of $\mathrm{Zn}_{2} \mathrm{SiO}_{4}$ in 72-68 Glass

$\begin{array}{rcc}25 \% & \frac{1200^{\circ} \mathrm{C} \text { Buttons }}{73 \mathrm{kcal}} & \frac{1000^{\circ} \mathrm{C} \text { Remelt }}{43 \mathrm{kcal}} \\ 50 \% & 76 \mathrm{kcal} & 42 \mathrm{kcal} \\ 75 \% & 84 \mathrm{kcal} & 42 \mathrm{kcal} \\ \text { Average }= & 79 \mathrm{kcal} & 42 \mathrm{kcal}\end{array}$
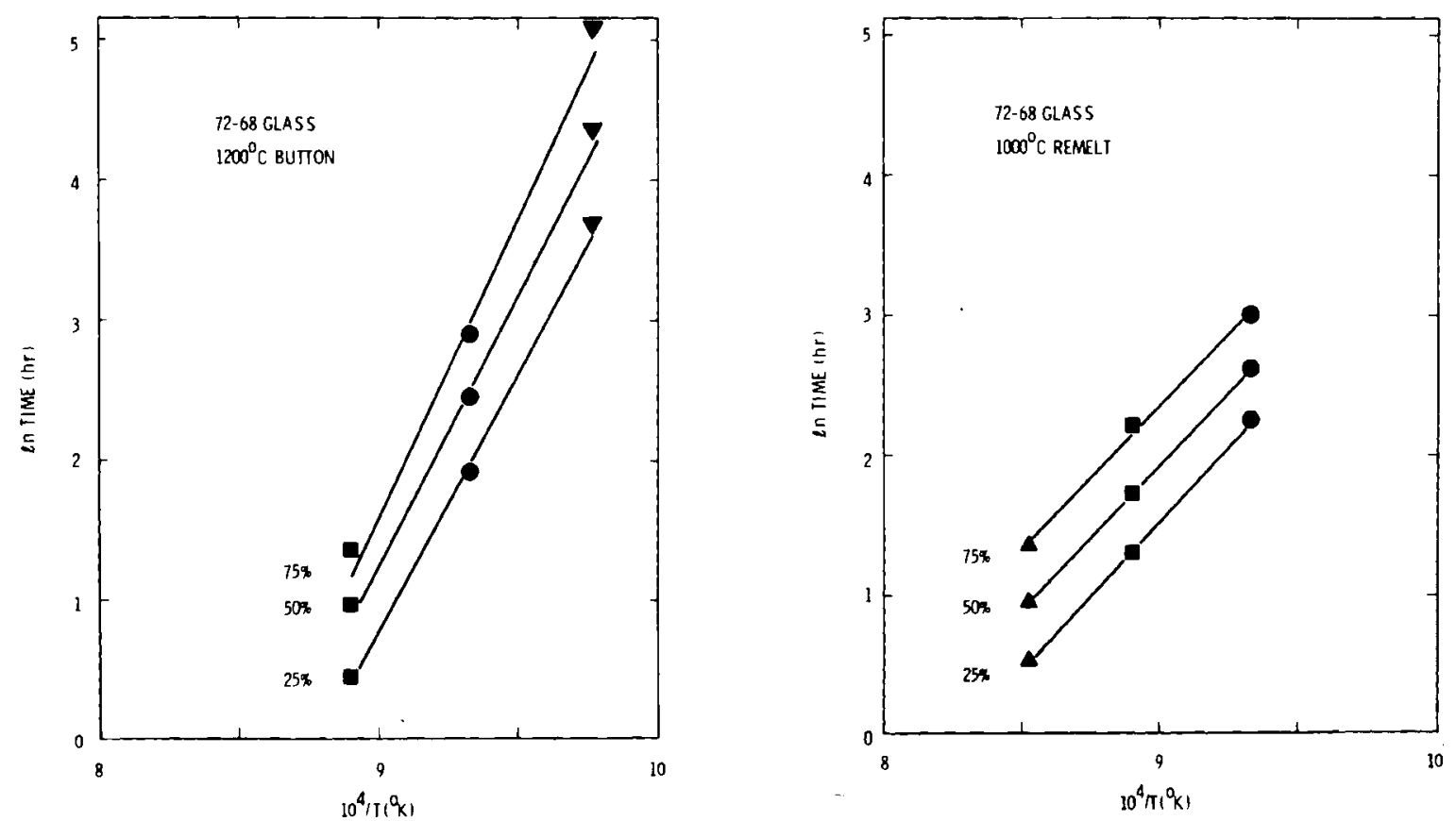

FIGURE 17. Time-Temperature Dependence for the Formation of $\mathrm{Zn}_{2} \mathrm{SiO}_{4}$ in 72-68 Glass 
The $1000^{\circ} \mathrm{C}$ results are in close agreement with results for the frit (73-1) as seen by comparison to Table 5 . The $1200^{\circ} \mathrm{C}$ buttons differ from the $1000^{\circ} \mathrm{C}$ samples primarily in that the fluorite phase $\left(\right.$ high $\left.\mathrm{CeO}_{2}\right)$ is not present. It crystallizes concurrently with $\mathrm{Zn}_{2} \mathrm{SiO}_{4}$ during lower temperature anneals, and apparently has a significant impact on measured activation energies. The numerical values $\left(\Delta H_{\text {meas }}\right)$ probably have enthalpy contributions from both reactions, since the $\mathrm{CeO}_{2}$ assists nucleation of $\mathrm{Zn}_{2} \mathrm{SiO}_{4}$. Figure 18 compares the results for $50 \%$ fractional ingrowth more directly, where the different behavior for the $1200^{\circ} \mathrm{C}$ glass is apparent. Perhaps the most remarkable feature here is the relatively small effect the presence of 26 wt\% fission product oxides has on the kinetics. For glasses prepared at $1000^{\circ} \mathrm{C}$, the frit (73-1) devitrified more slowly than the waste glass by a factor of 25 . The reason for the direction of change has probably more to do with increased ease of nucleation in the waste glass by insoluble crystallites than an actual change in growth rate. Figure 19 gives some striking examples of the influence of both $\mathrm{RuO}_{2}$ and $\mathrm{Pd}$ in nucleating $\mathrm{SrMoO}_{4}$ crystallization. Both the $\mathrm{Zn}_{2} \mathrm{SiO}_{4}$ phase and rare earth apatite phase are frequently observed to grow from $\mathrm{CeO}_{2}$, $\mathrm{RuO}_{2}$, or Pd microcrystals in a similar fashion.

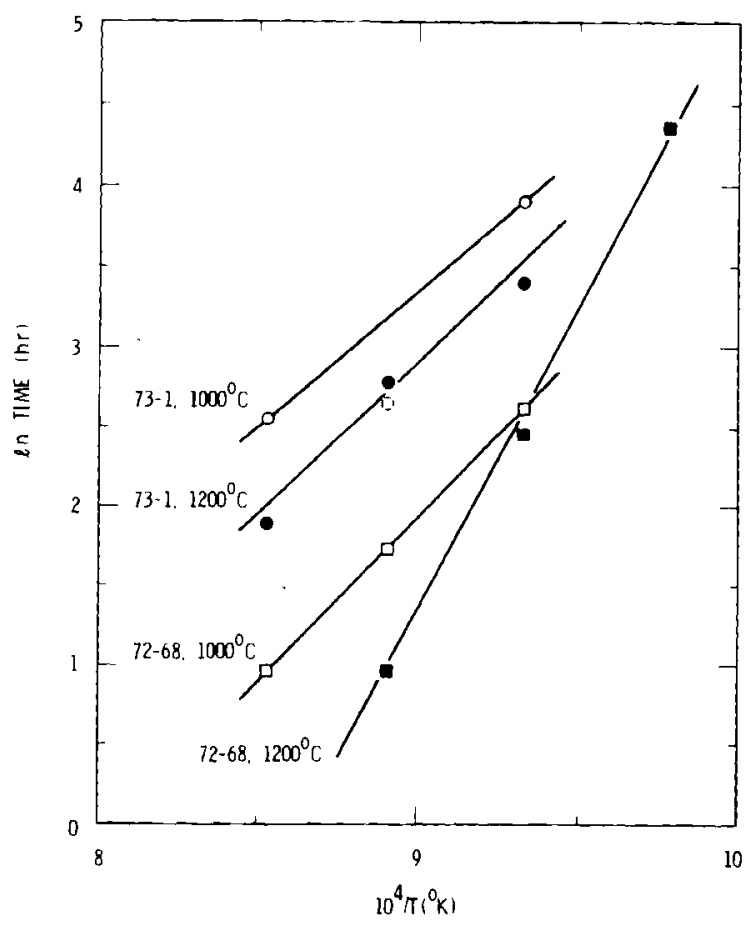

FIGURE 18. Time-Temperature Dependence for the Formation of $\mathrm{Zn}_{2} \mathrm{SiO}_{4}$ in Glasses 73-1 and 72-68 for 50\% Fractional Transformation 


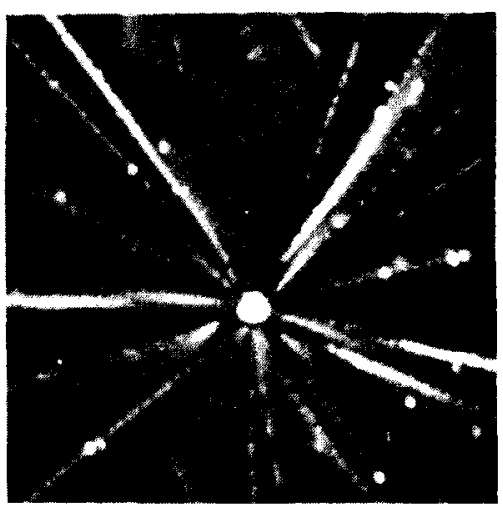

$8 \mu \mathrm{m}$
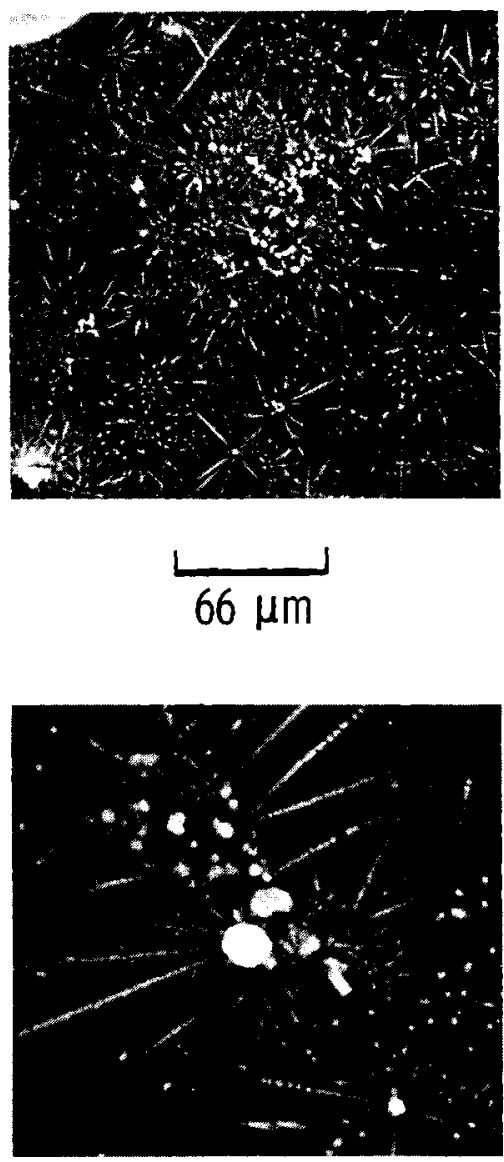

$17 \mu \mathrm{m}$

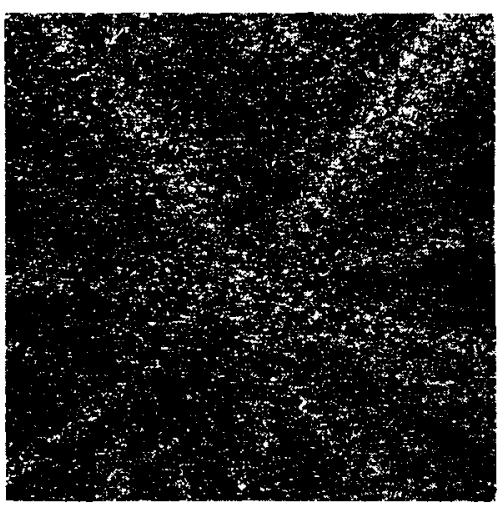

Mo

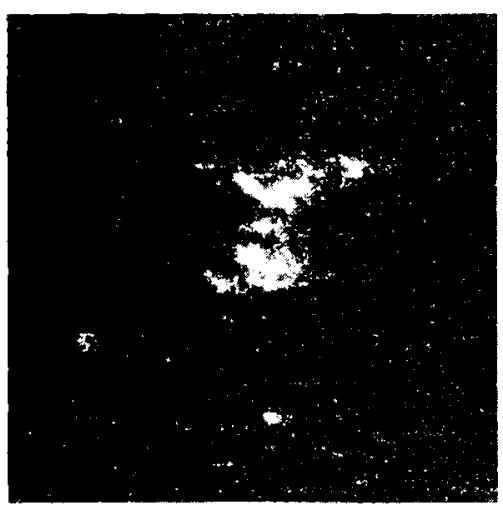

Ru

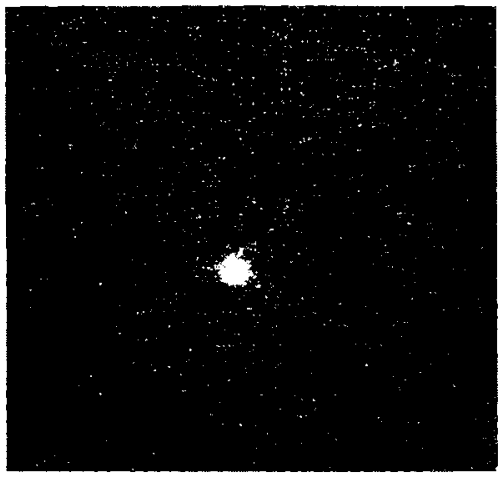

$\mathrm{Pd}$

FIGURE 19. SEM X-Ray Fluorescence Maps Illustrating the Effects of Nucleation Sites on the Formation of Crystalline Phases 


\section{Other Phases}

Figures 20 and 21 show the ingrowth behavior for the $\mathrm{SrMoO}_{4}$ and $\mathrm{CeO}_{2}$ phases, respectively. While the results for the molybdate phase follow more or less regular trends, the $\mathrm{CeO}_{2}$ data are not easily interpreted. For glass prepared at $1000^{\circ} \mathrm{C}$, the $\mathrm{CeO}_{2}$ content is $\sim 5 \mathrm{wt} \%$ and does not significantly change with annealing at lower temperatures. For the molybdate phase, the trend toward decreasing concentration with increasing temperature and the $\sim 900^{\circ} \mathrm{C} 1$ iquidous temperature are wel1 demonstrated (Figure 20). For both the $1000^{\circ}$ and $1200^{\circ} \mathrm{C}$ glasses the reaction is completed in $\sim 10 \mathrm{hr}$ at $750^{\circ} \mathrm{C}$ and in a few hours at $800^{\circ}$ and $850^{\circ} \mathrm{C}$.

The $\mathrm{RuO}_{2}, \mathrm{Pd}$, and spinel (trace amount) phases were not observed to vary in concentration throughout the course of this study. The growth of the rare apatite phase is probably very dependent on $\mathrm{Zn}$ concentration, since its growth generally occurs at $\mathrm{Zn}_{2} \mathrm{SiO}_{4} / \mathrm{glass}$ interface regions, where $\mathrm{Zn}$ concentration is low. Other data relative to these phases are given in Appendix A. 

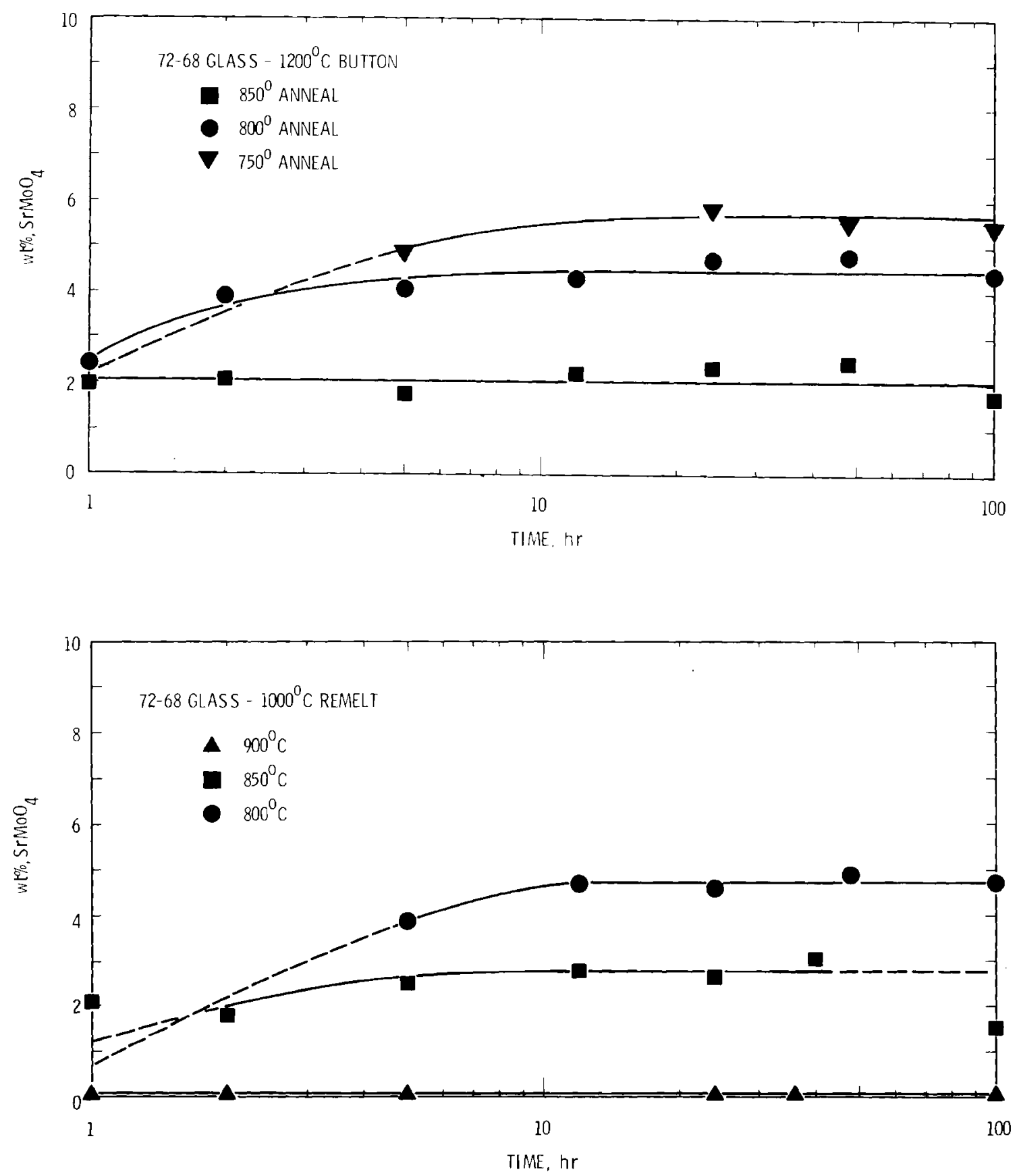

FIGURE 20. Ingrowth of $\mathrm{SrMoO}_{4}$ as a Function of Temperature at Short Times 

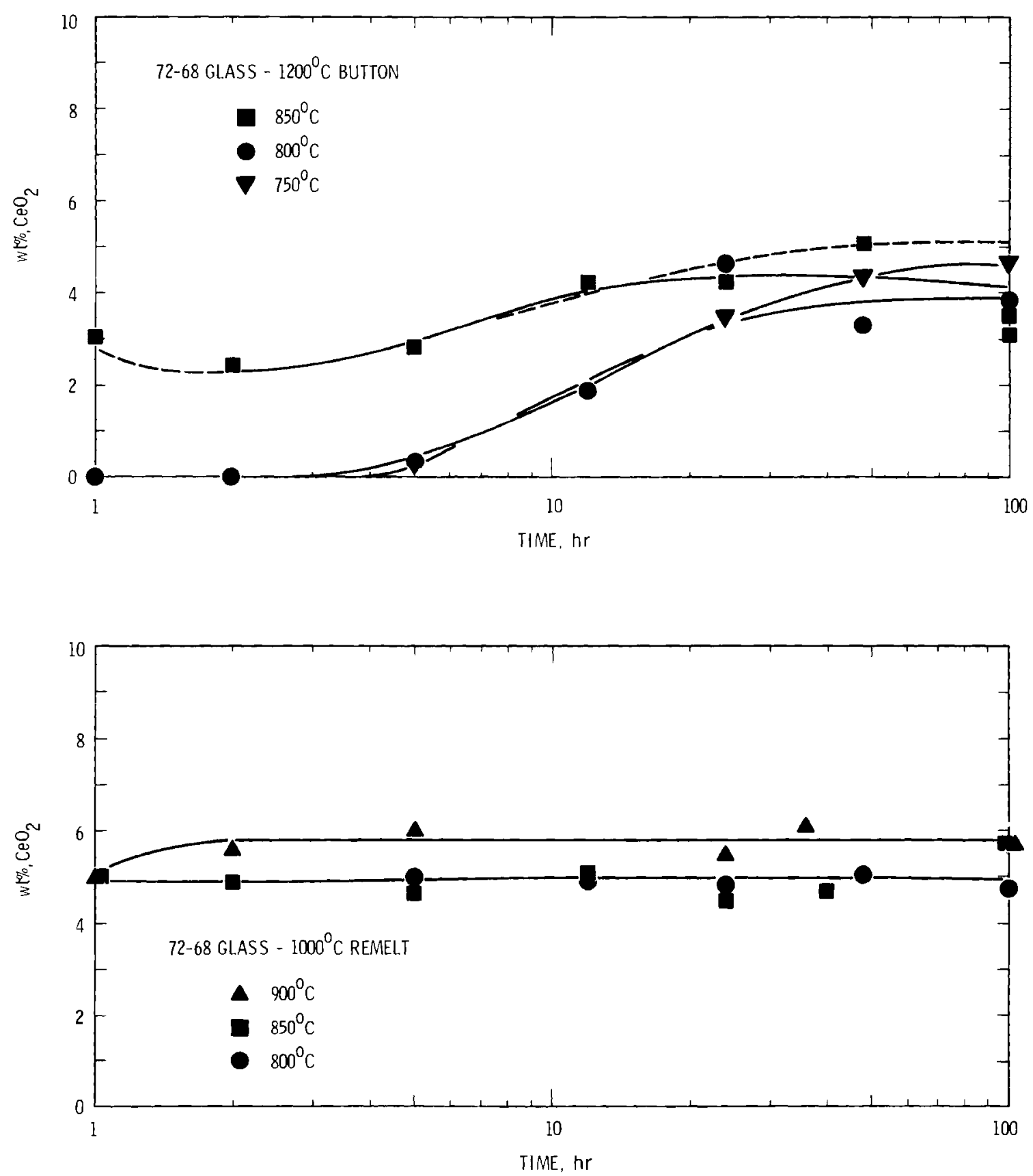

FIGURE 21. Ingrowth of $\mathrm{CeO}_{2}$ as a Function of Temperature at Short Times 


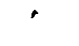




\section{CRUCIBLE AND GLASS FORM EFFECTS}

In simple glass systems, it is known that undissolved solids and melt surfaces as well as crucible interactions have some effect on devitrification behavior. To establish the importance of these variables, several peripheral studies were conducted. The effects of sample morphology, crucible material, crucible loading, and waste loading on the devitrification behavior were examined as described below.

SAMPLE MORPHOLOGY

In these experiments two types of sample morphologies were used: buttons and remelts. Buttons were formed by pouring a $1200^{\circ} \mathrm{C}$ melt from a platinum crucible into a graphite mold (preheated to $350^{\circ} \mathrm{C}$ ), holding for 30 minutes, and then air cooling to room temperature. Remelts were made by taking the glass in powder form, adding a measured amount to a small platinum crucible, and placing this crucible into the furnace at the desired preparation temperature $\left(1000^{\circ} \mathrm{C}\right)$ for a period of six to eight hours. When complete, the remelt was air cooled to room temperature. To identify possible phase behavior differences caused by samples prepared with the above two procedures, a test was designed using a $1200^{\circ} \mathrm{C}$ button and a $1200^{\circ} \mathrm{C}$ remelt both subsequently annealed at $850^{\circ} \mathrm{C}$ for 3.5 hours. X-ray diffraction analysis and optical metallography were performed with the major crystalline phases being examined as before. Table 7 gives the weight percent concentrations for the major constituents formed in the two cases.

TABLE 7. Weight Percent Formation of the Major Crystalline Phases for Buttons and Remelts Formed at $1200^{\circ} \mathrm{C}$ and Annealed at $850^{\circ} \mathrm{C}$ for $3.5 \mathrm{hr}$

$\begin{array}{lrl}\mathrm{Zn}_{2} \mathrm{SiO}_{4} & \frac{\text { Remelt }}{0 \mathrm{wt} \%} & \frac{\text { Button }}{2.5 \mathrm{wt} \%} \\ \mathrm{SrMoO}_{4} & 3.0 \mathrm{wt} \% & 2.2 \mathrm{wt} \% \\ \mathrm{CeO}_{2} & 1.4 \mathrm{wt} \% & 1.0 \mathrm{wt} \%\end{array}$


Figure 22 illustrates the two morphologies in cross section after devitrification. $\mathrm{Zn}_{2} \mathrm{SiO}_{4}$ crystals can be seen concentrated in regions which were formerly button surfaces; however, under the given conditions no $\mathrm{Zn}_{2} \mathrm{SiO}_{4}$ is seen in surface regions of the remelt sample. $\mathrm{SrMoO}_{4}$ seems to be rather uniformly distributed throughout both samples with no obvious preferential growth patterns. The wt\% values clearly show that constant sample geometries must be used for kinetic studies, al though equilibrium concentrations should not be affected.

\section{CRUCIBLE MATERIALS}

In order to evaluate the effects of crucible material on phase behavior, an experiment was performed using $304 \mathrm{~L}$ stainless steel, $\mathrm{Al}_{2} \mathrm{O}_{3}$, and platinum crucibles. Again, identical starting materials, preparation temperatures and devitrification schedules were used. The crucibles were equivalent in size and contained six grams of material each. Samples were remelted at $1000^{\circ} \mathrm{C}$ for $6 \mathrm{hr}$ and cooled to $800^{\circ} \mathrm{C}$ where they were held for $16.5 \mathrm{hr}$. X-ray diffraction results for in-growth appear in Table 8.

TABLE 8. Weight Percent Formation of the Major Crystalline Phases for Platinum, 304L Stainless Steel, and Alumina Crucibles Remelted at $1000^{\circ} \mathrm{C}$ and Annealed at $800^{\circ} \mathrm{C}$ for $16.5 \mathrm{hr}$

\begin{tabular}{|c|c|c|c|}
\hline & Platinum & 304L S.S. & $\mathrm{Al}_{2} \mathrm{O}_{3}$ \\
\hline $\mathrm{Zn}_{2} \mathrm{SiO}_{4}$ & $6.6 \mathrm{wt} \%$ & $6.0 \mathrm{wt} \%$ & $8.4 w t \%$ \\
\hline $\mathrm{SrMoO}_{4}$ & 3.9 wt $\%$ & $3.7 w t \%$ & $3.9 w t \%$ \\
\hline $\mathrm{CeO}_{2}$ & $5.3 w t \%$ & $1.2 \mathrm{wt} \%$ & $5.3 w t \%$ \\
\hline
\end{tabular}

Cross section photomicrographs of these three samples show no obvious surface effects. The lower concentration of ceria in the stainless steel crucible is probably due to the reduction of cerium from $\mathrm{Ce}^{+4} \rightarrow \mathrm{Ce}^{+3}$ and the increased solubility thereby achieved. The differences seen here also suggest that standardization of crucible material is necessary. 
REMELT
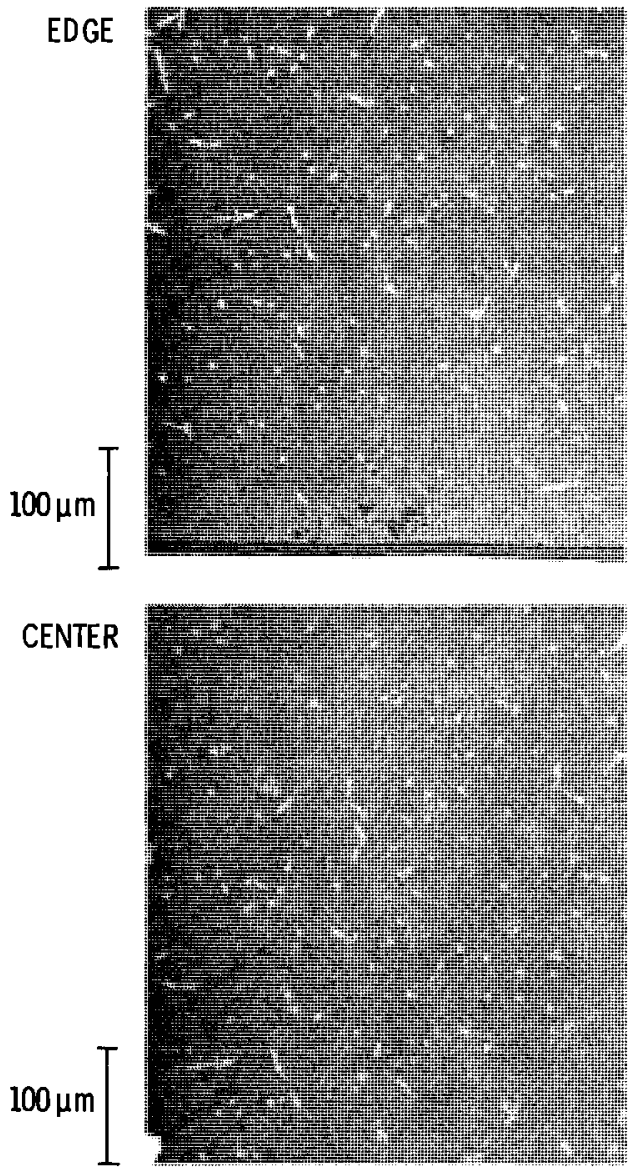

CENTER

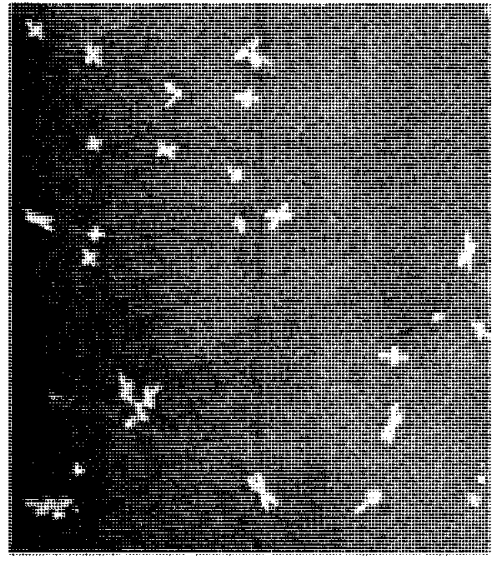

BUTTON
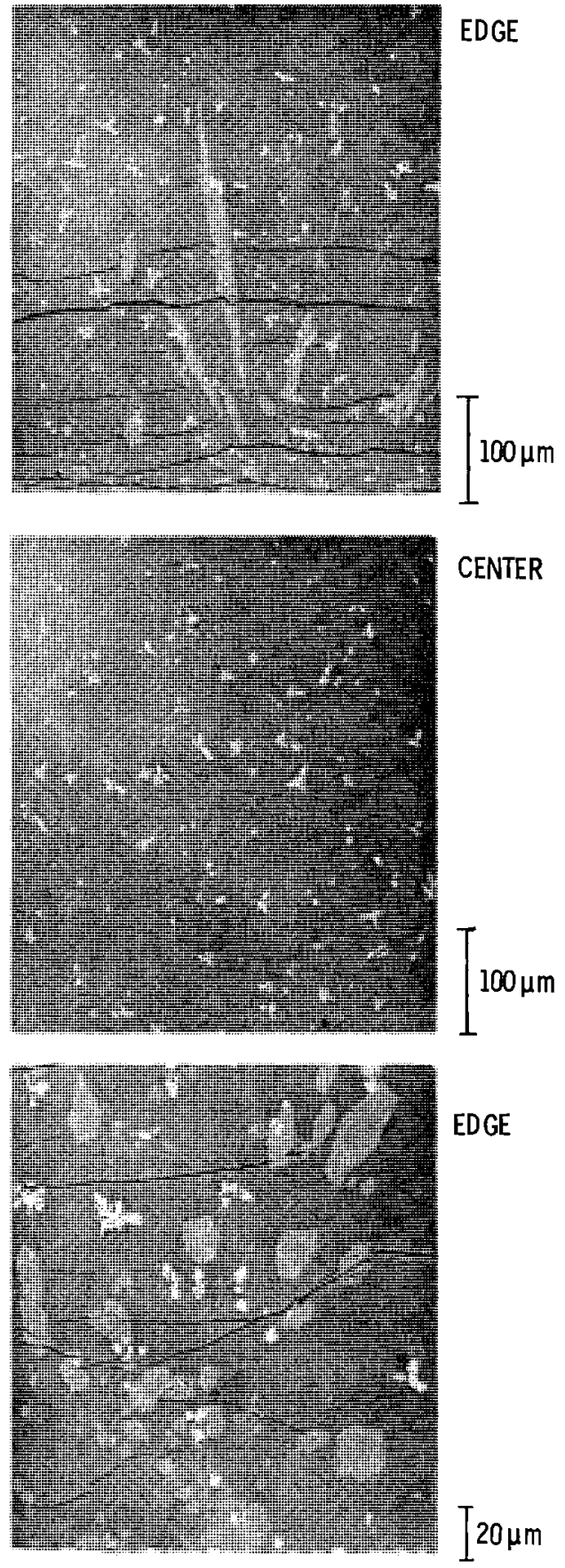

FIGURE 22. Effects of Sample Morphology on the Formation of $\mathrm{Zn}_{2} \mathrm{SiO}_{4}$ in 72-68 Glass 
Three identical $\mathrm{Al}_{2} \mathrm{O}_{3}$ cylindrical crucibles $18 \mathrm{~mm}$ diameter by $26 \mathrm{~mm}$ high were loaded with $2 \mathrm{~g}, 6 \mathrm{~g}$, and $12 \mathrm{~g}$ of glass powder, respectively. The glass was remelted at $1000^{\circ} \mathrm{C}$ and cooled to $800^{\circ} \mathrm{C}$ where it was held for $16.5 \mathrm{hr}$ and then air cooled to room temperature. The measured crystal yields given in Table 8 show only a small dependence with sample size. The surface to volume ratios for the $2 \mathrm{~g}, 6 \mathrm{~g}$, and $12 \mathrm{~g}$ are $9.8,4.8$, and 3.5, respectively, and based upon the data in Table 9 do not shc $r$ any significant trends.

TABLE 9. Weight Percent Formation of the Major Crystalline Phases at $2 \mathrm{~g}, 6 \mathrm{~g}$, and $12 \mathrm{~g}$ Loads in Standard $\mathrm{Al}_{2} \mathrm{O}_{3}$ Crucibles Remelted at $1000^{\circ} \mathrm{C}$ and Annealed at $800^{\circ} \mathrm{C}$ for $16.5 \mathrm{hr}$

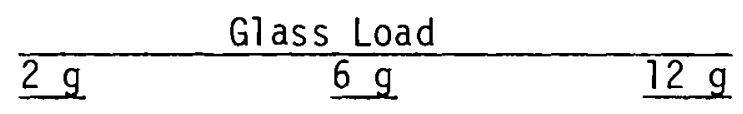

$\begin{array}{llll}\mathrm{Zn}_{2} \mathrm{SiO}_{4} & 7.1 \mathrm{wt} \% & 8.3 \mathrm{wt} \% & 8.8 \mathrm{wt} \% \\ \mathrm{SrMoO}_{4} & 3.5 \mathrm{wt} \% & 3.9 \mathrm{wt} \% & 4.0 \mathrm{wt} \% \\ \mathrm{CeO}_{2} & 5.0 \mathrm{wt} \% & 5.3 \mathrm{wt} \% & 4.5 \mathrm{wt} \%\end{array}$

\section{CALCINE/FRIT RATIO}

A waste loading experiment was performed where the fraction of calcine in the 73-1 frit varied from $30 \%$ to $0 \%$. The $72-68$ glass was diluted with 73-1 frit in proper amounts to give loadings of $25 \%, 20 \%, 15 \%, 10 \%$ and $5 \%$. Ten-gram batches of each loading were remelted in $\mathrm{Al}_{2} \mathrm{O}_{3}$ crucibles at $1000^{\circ} \mathrm{C}$ and subsequently annealed at $800^{\circ} \mathrm{C}$ for one week, a treatment which should yield $\sim$ equilibrium concentration of all phases. Weight percent $\mathrm{Zn}_{2} \mathrm{SiO}_{4}$ formed was again established using $X$-ray diffraction. The results, illustrated in Figure 23, show that the amount of $\mathrm{Zn}_{2} \mathrm{SiO}_{4}$ formed decreases with increasing load.

The decrease is only slightly greater than would be expected from assuming that the waste additions function only as a diluent. For example, at $20 \%$ waste, the dilution would give $\frac{18.7}{1.2}=15.6 \% \mathrm{Zn}_{2} \mathrm{SiO}_{4}$, whereas the 


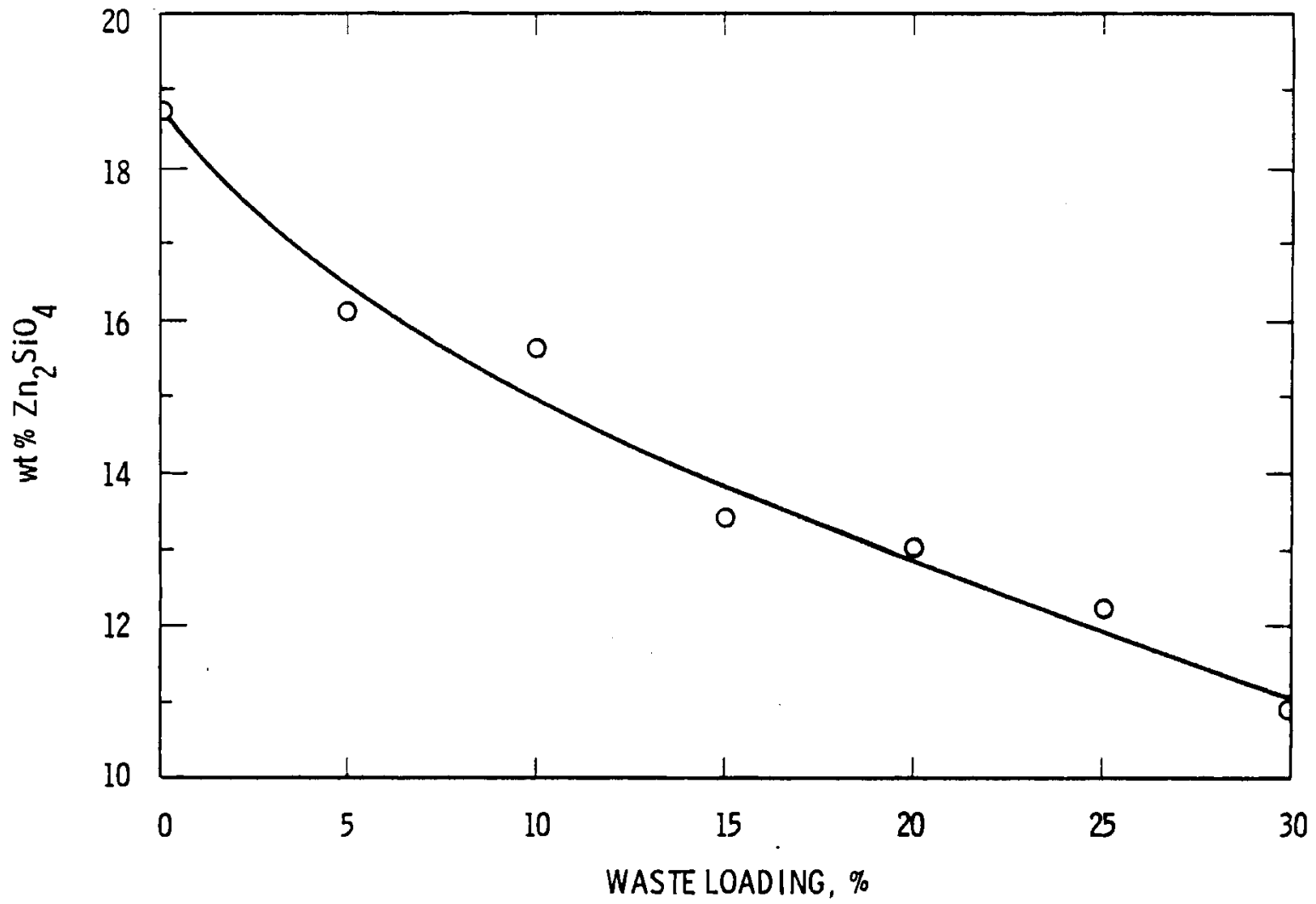
FIGURE 23. Effects of Total Waste Load on the Formation of $\mathrm{Zn}_{2} \mathrm{SiO}_{4}$ in
$72-68$ Glass

measured concentration was $13 \%$. This result is not expected to be the "usual" case. Other workers, ${ }^{(6)}$ for example, find that the major devitrification products in other glass frits do not form at all after addition of fission product wastes. In the present case, there is no major interaction of $\mathrm{Zn}$ with the fission product elements. 


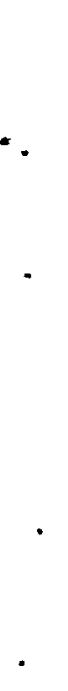




\section{APPLICATION TO WASTE DISPOSAL AND CONCLUSIONS}

\section{APPLICATION}

The preceding sections and the appendices demonstrate that therma 1 crystallization of waste glasses is a complex process, but general behavior follows expected trends. This is true with respect to both the reaction rates and the establishment of a steady state, which is composed of a residual glass phase in equilibrium with a comparatively limited number of crystal1 ine phases. The consequences of this crystallization depend on other factors but clearly will affect chemical durability (1eaching by groundwaters) and the long-time importance of radiation damage (nonhomogeneous damage in a crystallized glass). If optimum and predictable behavior are desired, it is important to produce a homogeneous product with a minimum crystal content.

The conditions required to achieve minimum crystal content can be specified by application of the results obtained in this study. To do so, it is convenient to consider several time/temperature frames of reference:

a) hours-months - During processing and early storage (including hypothetical accident scenarios) high temperatures, 400 to $1000^{\circ} \mathrm{C}$, could be reached for short times.

b) years-decades - Depending on the self-heating characteristics of the waste and details of geologic repository management, temperatures in the range $100-500^{\circ} \mathrm{C}$ may be experienced for relatively long periods.

c) times after 100 years - Depending on burial depth, and after most of the short-lived fission products have decayed, ambient temperatures wi11 be $30-100^{\circ} \mathrm{C}$.

With respect to thermally induced changes in glass systems, it is well known that under anhydrous conditions, changes occur very slowly at temperatures below the glass softening point. For waste glasses, this means 
that laboratory studies extending even over several years will yield useful information only for temperatures greater than about $500^{\circ} \mathrm{C}$, as in the present work. The prediction of thermally induced changes under conditions (b) and (c) above therefore must rely on studies of type (a) undertaken in enough detail that extrapolation can be justified.

A brief discussion of crystallization theory is presented in Appendix B, where it is shown that the present glass is "wel1-behaved." The temperature dependence for growth of the major phase $\left(\mathrm{Zn}_{2} \mathrm{SiO}_{4}\right)$ is approximately as calculated, using experimental data for the heat of crystallization and the glass viscosity. The isothermal studies discussed in Sections 3 and 4 also suggest the system is "well-behaved," even though the glass is not entirely homogeneous in the as-prepared condition. Based on these observations, we can extrapolate experimental results to include conditions described above and shown schematically in Figure 24. Actual cooling histories can be approximated by a series of isothermal steps as shown, considering the centerline temperatures. The thermal history projections are based on current processing and storage methods for In-Can-Melt (ICM) glasses as presented by Mendel et al. for one-year-old waste. ${ }^{(5)}$ In general, the curves in Figure 24 reflect temperature controls which exclude a detailed consideration of the effects on the glass product, as these are being defined.

It may be noted in Figure 24 that cooling rates at the canister wall are very rapid relative to the centerline behavior. A 12-in.-diameter finned canister was assumed; if larger canisters are used, the differences between wall and centerline cooling will be even larger. As shown by the w 10 -hr temperature rise shortly after fabrication, the canisters will be removed from the cooling basin for examination. Following this inspection, they will probably be held in cooling basin storage for several years before transfer to geologic storage. Because the repository will be gradually filled, temperatures there will rise to a maximum only after 210 years, after which self heating is controlled by the half-lives of the major fission products. 


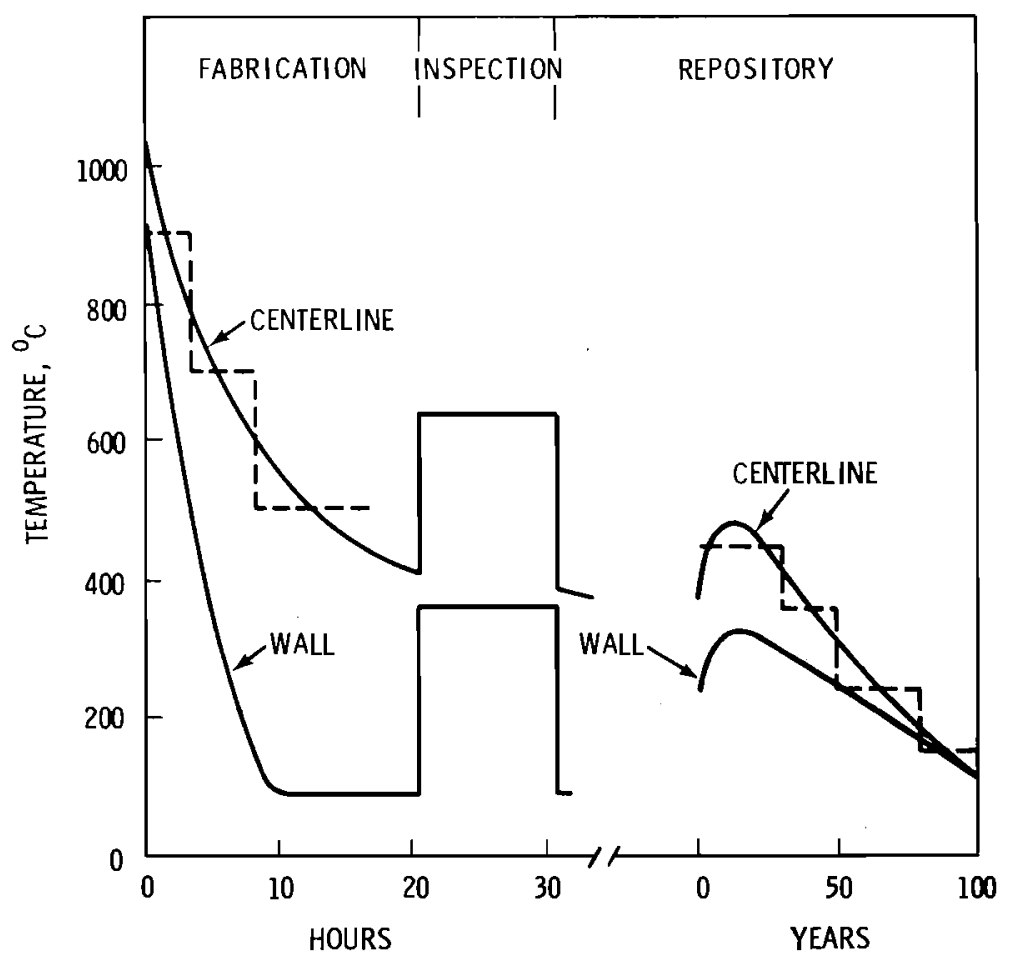

FIGURE 24. Expected Canister Thermal History as a Function of Time after Vitrification

For glass (72-68), ingrowth behavior of the major devitrification product $\left(\mathrm{Zn}_{2} \mathrm{SiO}_{4}\right)$ is summarized in Figure 25 by several lines plotted as log time vs 1/T. The cross-hatched area reflects the experimentally accessible region from which long-time behavior must be extrapolated. Curve (a) is obtained by a consideration of times required to reach equilibrium concentrations (i.e. from Figure 8). Note that the achievable concentration of $\mathrm{Zn}_{2} \mathrm{SiO}_{4}$ is temperature dependent, reaching the theoretical maximum of $\sim 30 \mathrm{wt} \%$ only for temperatures less than $350^{\circ} \mathrm{C}$. Curve (b) represents the induction time required to begin crystallization, estimated from the zero-fraction intercepts in Figures 15 and 16. Curve (c) is based on our examination of this glass after annelaing for one year. At $500^{\circ} \mathrm{C}$ there is no measurable change in crystal content from the as-prepared condition, hence the induction time must be one year or more. As a point of comparison, curve (d) shows an estimate given by Marshall, (7) which defines devitrification of naturally occurring volcanic glasses. It is clear that the kinetics are not much different. 


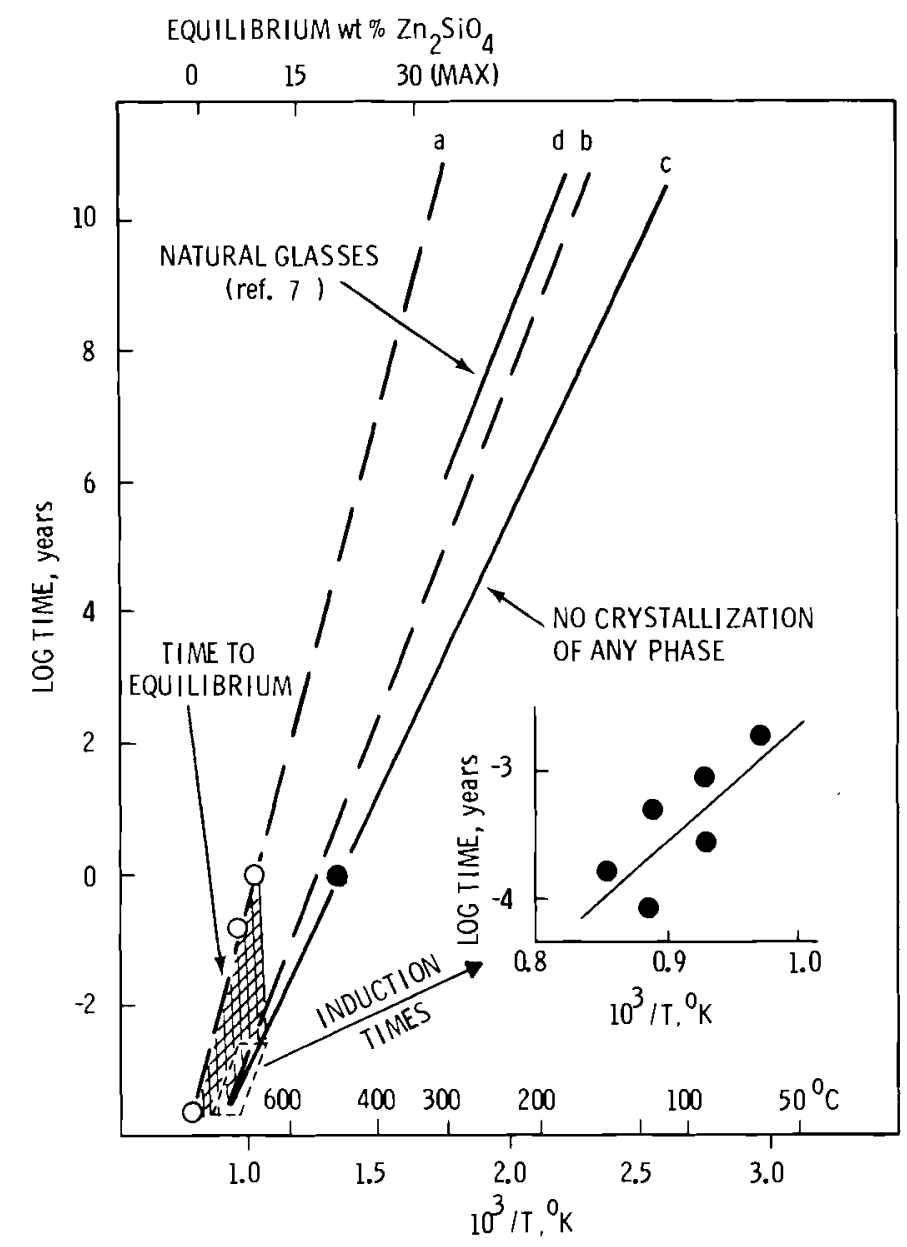

FIGURE 25. Extrapolation of Experimental Results to Long Times and Low Temperatures

Considering $10^{6}$ years as an example of the application of Figure 25 , equilibrium crystal yields would be expected for $\mathrm{T}>450^{\circ} \mathrm{C}$, trace yields of $\mathrm{Zn}_{2} \mathrm{SiO}_{4}$ at $275^{\circ} \mathrm{C}$, and no crystallization would occur for $\mathrm{T}<225^{\circ} \mathrm{C}$.

The expected cooling history shown in Figure 24 can be considered in a similar fashion, using the step function approximation indicated for centerline temperatures. Table 10 gives the results of such an analysis for formation of $\mathrm{Zn}_{2} \mathrm{SiO}_{4}$. During processing some crystallization would occur near the centerline (2\%) and may approach the equilibrium yield after 30 years in geologic storage if the temperatures indicated are realized. Near the wall of the canister, the glass would remain vitreous for more than $10^{8}$ years. 
TABLE 10. Centerline Devitrification Estimates Based on Figure 24

\begin{tabular}{ccc} 
Temperature, ${ }^{\circ} \mathrm{C}$ & Step Time & $\underline{Z n}_{2} \underline{S i O}_{4}$, wt\% \\
\cline { 2 - 3 } 900 & $3 \mathrm{hr}$ & 2 \\
700 & $5 \mathrm{hr}$ & 0 \\
500 & $12 \mathrm{hr}$ & 0 \\
650 & $10 \mathrm{hr}$ & 0 \\
& & \\
450 & $30 \mathrm{yr}$ & 20 \\
350 & $20 \mathrm{yr}$ & 0 \\
250 & $30 \mathrm{yr}$ & 0 \\
150 & $20 \mathrm{yr}$ & 0
\end{tabular}

With respect to other crystallization products, $\mathrm{SrMoO}_{4}$ would form more rapidly and the rare earth apatite phase more slowly than $\mathrm{Zn}_{2} \mathrm{SiO}_{4}$. The rate differences are not actually very large, however, as shown by the fact that samples anealed one year at $500^{\circ} \mathrm{C}$ show no crystallization while those annealed at $600^{\circ} \mathrm{C}$ produce large yields for all phases.

The time/temperature requirements needed to entirely avoid crystallization in the present glass are estimated as follows (the high temperature period during and shortly after fabrication can be considered using the inset given in Figure 25): at $900^{\circ} \mathrm{C}$ an induction time of $\sim 1 \mathrm{hr}$ is indicated, at $800^{\circ} \mathrm{C} \sim 4 \mathrm{hr}$, and at $700^{\circ} \mathrm{C} \sim 20 \mathrm{hr}$. On this basis, a 10-hr period shortly after fabrication in which the waste canister might be examined/ decontaminated outside of the water cooling basin (centerline $\rightarrow 2650^{\circ} \mathrm{C}$, Figure 24) would cause no crystallization. For in-repository storage, 30 years at a temperature of $375^{\circ} \mathrm{C}$ is acceptable. At $300^{\circ} \mathrm{C}$ the induction time for crystallization should be 25000 years if a large margin of 'sureness' is desired. Several options of this kind are shown schematically in Figure 26, considering centerline temperatures. By comparison to Figure 24 it may be noted that for glass (72-68) a more rapid cool from the melt is needed, and the maximum repository temperature should be $\sim 375^{\circ} \mathrm{C}$. These two conditions are directly affected by the glass composition and may be considerably 
relaxed in the direction of slower allowable cooling rates and higher repository temperatures as improved glasses are developed. Also, below $800^{\circ} \mathrm{C}$, cooling for this glass during fabrication can be much slower than obtained by water quenching (i.e. there is the possibility of annealing the glass). If desirable, the repository could be managed in such a way that relatively high temperatures would be maintained for many decades (assuming anhydrous conditions are maintained).

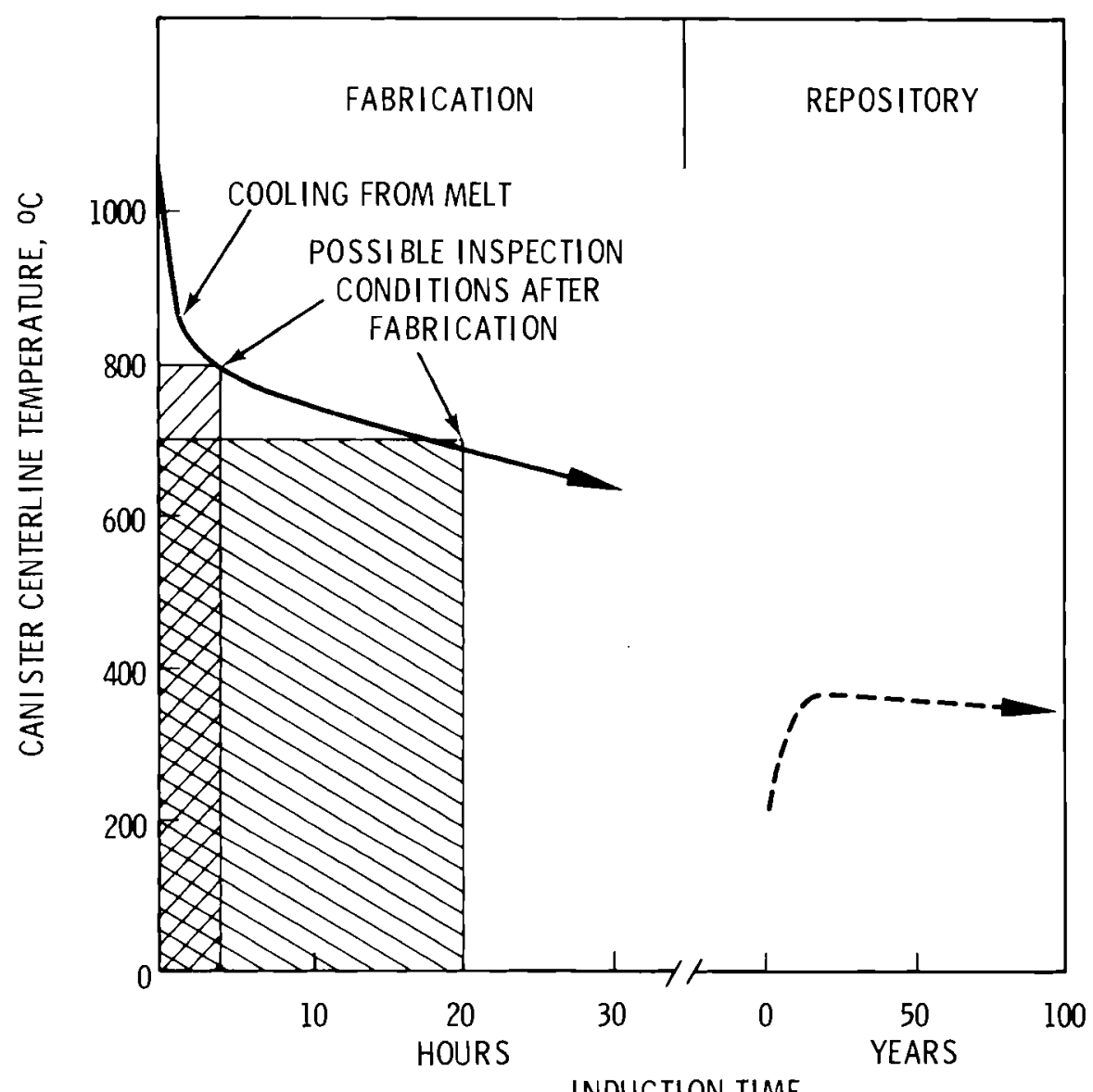

FIGURE 26. Time-Temperature Relationships to Retain a Vitreous Glass Product 


\section{CONCLUSIONS}

The major conclusions of this study are summarized as follows:

- Crystal yields in glass (72-68) approach limiting concentrations that depend on temperature in accordance with the usual concepts of chemical equilibria.

- Ingrowth kinetics are sensitive to experimental artifacts (e.g. prior melt temperature and crucible material) but show a temperature dependence in agreement with theoretical behavior.

- The major phase $\left(\mathrm{Zn}_{2} \mathrm{SiO}_{4}\right)$ ingrows with an activation energy of 42 $\mathrm{kcal} / \mathrm{mole}$. Kinetics are not sensitive to the waste loading. A thermal expansion mismatch with the glass matrix causes extensive microcracking.

- Extrapolations of this study to include expected processing and storage conditions define optimum thermal controls not greatly different than those now assumed or planned. A maximum repository temperature, limiting canister centerline temperatures to $\angle 375^{\circ} \mathrm{C}$, is desirable for glass (72-68). 


\section{REFERENCES}

1. Proceedings of ENEA/IAEA Symposium on Management of Radioactive Waste from Fuel Reprocessing, Paris, December 1972.

2. "Management of Radioactive Wastes from the Nuclear Fuel Cycle." IAEA Proceedings, Vienna, 1976.

3. J. E. Mendel et al., "Thermal and Radiation Effects on Borosilicate Waste Glasses," IAEA Proceedings, Vienna, II,49 (1976).

4. J. E. Mendel, A Program Plan for Comprehensive Characterization of Sol idified High Level Wastes. BNWL-1940, Battelle, Pacific Northwest Laboratory, Richiand, WA 99352, December 1975.

5. J. E. Mende1, Annual Report on the Characteristics of High-Level Waste Glasses. BNWL-2252, Battelle, Pacific Northwest Laboratories, Richland, WA 99352, June 1977.

6. A. D. De' et a1., Ceramic Bulletin, 55,500 (1976).

7. R. R. Marsha11, Bul1. Geol. Soc. Am, 72,1493 (1961). 
APPENDIX A

SUMMARY OF DEVITRIFICATION PRODUCTS 


\section{APPENDIX A}

\section{SUMMARY OF DEVITRIFICATION PRODUCTS}

The following descriptions summarize major characteristics of crystalline phases observed in glass (72-68).

$\mathrm{Zn}_{2} \mathrm{SiO}_{4}$

Maximum theoretical concentration is $29.1 \mathrm{wt} \%$. The concentration after one year at $600^{\circ} \mathrm{C}$ is $14 \mathrm{wt} \%$. The crystals are the largest type formed, appearing with hexagonal symmetry of columnar form with a length to diameter ratio of $\sim 500 \mu \mathrm{m} / 100 \mu \mathrm{m}$ at temperatures $\sim 900^{\circ} \mathrm{C}$. At $700^{\circ} \mathrm{C}$ the size is $\sim 100 \mu \mathrm{m} / 20 \mu \mathrm{m}$ and smaller. Annealing at $700^{\circ} \mathrm{C}$ for one year does not obviously change the crystal size distribution from that seen after one week, although one crystal was observed in the one-year sample with a small axis dimension near $1 \mathrm{~mm}$. The $\mathrm{Zn}_{2} \mathrm{SiO}_{4}$ formed is quite pure, with good agreement between expected and measured lattice parameters $\left(a_{0}=13.97 \AA, c_{0}=9.30 \AA\right)$. The position of the (113) reflection used for quantitative analysis was constant for all samples at the theoretical position, suggesting that no stoichiometry change occurs with annealing time. Extensive microcracking occurs in the crystallized glasses as a result of the small and anisotropic thermal expansion coefficients for $\mathrm{Zn}_{2} \mathrm{SiO}_{4}$, which are $4.3 \times 10^{-6}$ and $2.7 \times 10^{-6}$ $\left(25-300^{\circ} \mathrm{C}\right)$ in the $\underline{c}$ and a directions, (1) respectively. These may be compared to the glass value of $\alpha=9 \times 10^{-6}\left(25-300^{\circ} \mathrm{C}\right)$. (2)

\section{$(\mathrm{Ca}, \mathrm{Sr}, \mathrm{Ba}) \mathrm{MoO}_{4}$}

Maximum theoretical concentration is $6.9 \mathrm{wt} \%$. The concentration after one year at $600^{\circ} \mathrm{C}$ was $6 \mathrm{wt} \%$. On a molar basis this is the major compound formed containing fission products. Its composition is not constant with time, being initially formed with high $\mathrm{Ca}$ and $\mathrm{Sr}$ content, but with a gradual increase in the $\mathrm{Ba}$ content as calcium reconcentrates in the RE apatite phase. Microprobe analyses of samples heated one day and two months 
at $750^{\circ} \mathrm{C}$ gave the respective compositions $\left(\mathrm{Ca}_{0.34} \mathrm{Sr}_{0.56} \mathrm{Ba}_{0.12}\right) \mathrm{MoO}_{4}$ and $\left(\mathrm{Ca}_{0.24} \mathrm{Sr}_{0.56} \mathrm{Ba}_{0.21}\right) \mathrm{MoO}_{4}$. The lattice constants at short times for this tetragonal (Sheelite structure) compound are $a_{0}=5.38 \AA$ and $c_{0}=12.03 \AA$. The visual appearance of the dendritic crystals does not significantly change over the one-year anneal. The crystals form a three-dimensional (dendritic) lattice structure throughout the glass, extending as much as $1 \mathrm{~mm}$ in length, and individual crystals have a diameter $\sim 0.002 \mathrm{~mm}$.

\section{APATITE}

Maximum theoretical concentration is $8.1 \mathrm{wt} \%$. After one year at $600^{\circ} \mathrm{C}$, the concentration was $3 \mathrm{wt} \%$. This rare earth silicate forms in the glass at temperatures $600<\mathrm{T}^{\circ} \mathrm{C}<800$ only after significant formation of $\mathrm{Zn}_{2} \mathrm{SiO}_{4}$. The hexagonal crystals generally appear associated with $\mathrm{Zn}_{2} \mathrm{SiO}_{4}$ crystals, most likely nucleating in $\mathrm{Zn}$-depleted regions at the $\mathrm{Zn}_{2} \mathrm{SiO}_{4}$-glass interface. The identification of this phase by $x$-ray diffraction is complicated by overlapping reflections with other higher concentration phases. Only the (102) and (300) peaks are clearly seen (Figure 6). The lattice parameters (hence composition) vary slightly with temperature and time. After two months at $700^{\circ} \mathrm{C}$ the hexagonal cell constants are $a_{0}=9.54 \AA$ and $c_{0}=7.16 \AA$. Unlike zinc silicate, these large crystals do not appear to cause microcracking. The thermal expansion coefficients for a related compound of the apatite structure were reported ${ }^{(3)}$ as $9.6 \times 10^{-6}$ for both $\underline{a}$ and $\underline{c}$ directions. If the present apatite phase(s) have similar constants (i.e., close to the glass value) no cracking should occur. Microprobe analysis of the two-month annealed sample $\left(700^{\circ} \mathrm{C}\right)$ suggested a rare earth composition $\left(\mathrm{Nd}_{0.47} \mathrm{Pr}_{0.21} \mathrm{La}_{0.20} \mathrm{Sm}_{0.07} \mathrm{Gd}_{0.05}\right)$ and a molar ratio RE/Si 27 . Calcium is also a major constituent. Some phosphorous is also present, although with a molar ratio $\mathrm{Si} / \mathrm{P}=78$ in the original glass, a large contribution is not possible. Nonstoichiometric compositions are to be expected. The phase stoichiometry in this case probably has boundaries given by the compositions $(\underline{\mathrm{Ca}}, \mathrm{Zn})_{2}(\mathrm{La}, \underline{\mathrm{Nd}}, \mathrm{Pr})_{8}\left(\mathrm{SiO}_{4}\right)_{6} \mathrm{O}_{2}$ and $(\underline{\mathrm{Ca}}, \mathrm{Zn})_{4}(\mathrm{La}, \underline{\mathrm{Nd}}, \mathrm{Pr})_{6}\left(\mathrm{SiO}_{4}\right)_{6} \mathrm{O}$. 
$\left(\mathrm{Ce}, \mathrm{Zr}, \mathrm{RE}^{3+}\right) 0_{2-x}$

Maximum theoretical concentration is $8.5 \mathrm{wt} \%$. After one year at $600^{\circ} \mathrm{C}$ the measured concentration was $\sim 5 \mathrm{wt} \%$. A fluorite-structure-type cubic phase was present in a 17 samples except for glass quenched from $1200^{\circ} \mathrm{C}$. Lattice parameters vary over the range 5.33-5.39 $\AA$. The composition varies somewhat with time and depends on the glass melting temperature. After four days annealing at $850^{\circ} \mathrm{C}$, a $1200^{\circ} \mathrm{C}$ melt gave $a_{0}=5.35 \AA$, compared to $a_{0}=5.39 \AA$ for the $1000^{\circ} \mathrm{C}$ melt. Because the crystals are very small $(<2 \mu \mathrm{m})$, microprobe analysis could only establish the presence of $\mathrm{Zr}$ and the rare earth elements in this phase, but not accurate concentrations. The phase stoichiometry is most appropriately given as $\left(\mathrm{Ce}^{4+}, \mathrm{Zr}^{4+}, \mathrm{RE}^{3+}\right) \mathrm{O}_{2-\mathrm{x}}$.

SPINEL

Maximum theoretical concentration is $22 \mathrm{wt} \%$. Clusters of regular cubic crystals were often observed in optical micrographs although no corresponding $x$-ray diffraction peaks were ever seen. Microprobe analysis showed two stoichiometries present (even as neighboring crystals) in proportions appropriate to the spinel structure type $\left(\mathrm{M}_{3} \mathrm{O}_{4}\right)$. The devitrified glass is magnetic, suggesting the oxide present has the inverse spinel structure with $\mathrm{B}^{3+}$ ions occupying both tetrahedral and octahedral sites. The stoichiometries measured in a sample annealed one week at $600^{\circ} \mathrm{C}$ suggest compounds $\left(\mathrm{Fe}_{0.9^{\mathrm{Cr}}}{ }_{0.1}\right)\left(\mathrm{Zn}_{0.6} \mathrm{Ni}_{0.4} \mathrm{Fe}_{0.9} \mathrm{Cr}_{0.7}\right) \mathrm{O}_{4}$ and $\left(\mathrm{Fe}_{0.5} \mathrm{Cr}_{0.5}\right)\left(\mathrm{Zn}_{0.8} \mathrm{Ni}_{0.2} \mathrm{Fe}_{0.5} \mathrm{Cr}_{0.5}\right) \mathrm{O}_{4}$ with a clear indication of $\mathrm{Zn}$ attack on originaliy $\mathrm{Zn}$-free crystals. Since microprobe analysis of the glass matrix shows no depletion of iron after devitrification, and no $x$-ray diffraction evidence for existence of spinel was obtained, the concentration of this phase is $<0.3 \mathrm{wt} \%$.

$\mathrm{RuO}_{2}$

Maximum theoretical concentration is $1.9 \mathrm{wt} \%$. The ruthenium oxide phase was present in the vitreous glass as very fine crystals, often nucleating devitrification phases. Microprobe analysis showed no Ru in 
the glass phase, and diffraction intensity is compatible with its expected concentration of $1.9 \mathrm{wt} \%$. The measured lattice parameters for the tetragonal unit cell of $a_{0}=4.50 \AA$ and $c_{0}=3.10 \AA$ are in good agreement with those expected for the pure compound. Concentrations varied from sample to sample.

$\underline{P d}$

Maximum theoretical concentration is $0.8 \mathrm{wt} \%$. Palladium separated from the glass during vitrification as micro-spheres of apparent high purity. At 1 atm $0_{2}$, the decomposition PdO $\rightarrow$ Pd occurs at $870^{\circ} \mathrm{C}$ so that observation of the free metal is not surprising. The sma 11 microspheres serve as nucleation sites for the growth of other phases. The measured lattice parameter for the cubic cell was $a_{0}=3.90 \AA$, in good agreement with that for the pure metal.

$\underline{\mathrm{Rh}}$

Maximum theoretical concentration is $00.3 \mathrm{wt} \%$. Rhodium appears in low-temperature-melted glasses as an irregular light contrast phase in some of the micrographs. It dissolves at high temperatures $\left(1200^{\circ} \mathrm{C}\right)$ and did not appear to have any role in devitrification. Its maximum concentration was only $0.24 \mathrm{wt} \%$ and in the form of relatively large agglomerates was not a significant nucleating agent. No contribution to the $x$-ray diffraction pattern was found. Rh was added to the present glass as the pure oxide, rather than as part of the spray calcine. Were it added in the latter highly reactive form, it might well have been incorporated in the glass phase at lower temperatures. 


\section{- REFERENCES - APPENDIX A}

1. Y. S. Toulonkian, editor, Thermophysical Properties of High Temperar ture Materials, Vol. 4, pt. 2, p. 1342, MacMillan Co., N.Y. 1967.

2. J. E. Mendel et al., Annual Report on the Characteristics of High-Level Waste Glasses. BNWL-2252, Battelle, Pacific Northwest Laboratories, Richland, WA 99352; p. 40, June 1977.

3. R. H. Hopkins et a1., J.App1. Phys. 42,272 (1971).

4. W. L. Wanmaker, J. W. ter Vrugt, J. G. Verlijsdonk, J. Sol State Chem. $\underline{3}, 452(1971)$. 


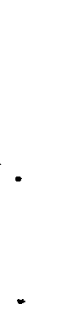


APPENDIX B

GLASS CRYSTALLIZATION - THEORETICAL CONSIDERATIONS 
APPENDIX B

\section{GLASS CRYSTALLIZATION - THEORETICAL CONSIDERATIONS}

It is shown in Section 3 of this report that equilibrium appears to be reached in the waste glass system at temperatures above $800^{\circ} \mathrm{C}$ after annealing periods of less than two months. There is of course no way to predict either the composition or concentration of the many phases present from thermodynamic principals in so complex a system even with an enormous experimental effort. Some useful concepts can nevertheless be applied to outline an understanding of what to expect. If we consider a "simple" case of one crystalline product and its equilibria with the glass, then a schematic free energy diagram can be drawn as in Figure B-l, where at Composition A the crystalline phase is entirely dissolved in the glass or entirely precipitated at B. As drawn, a minimum free energy occurs at some intermediate composition, which changes with temperature. The glass at composition $A$ becomes stable with respect to precipitation of the crystalline phase (i.e. the liquidous temperature is reached) at $1100^{\circ} \mathrm{C}$, where the free energy change is positive with

a change toward composition B. At lower temperatures it is clear that Glass $A$ will change composition as the temperature is decreased from the $1100^{\circ} \mathrm{C}$ liquidous temperature in order to achieve the minimum free energy. Increasing fractional yields will be observed as suggested in Figure $\mathrm{B}-2$ as related to the free energy minima in Figure $\mathrm{B}-1$.

The free energy change involved in a single crystallization reaction is given in the usual manner as

$$
\Delta G=\Delta H^{\circ}-T \Delta S^{\circ}
$$

where

$$
\Delta G^{\circ}=-R T \ln K
$$




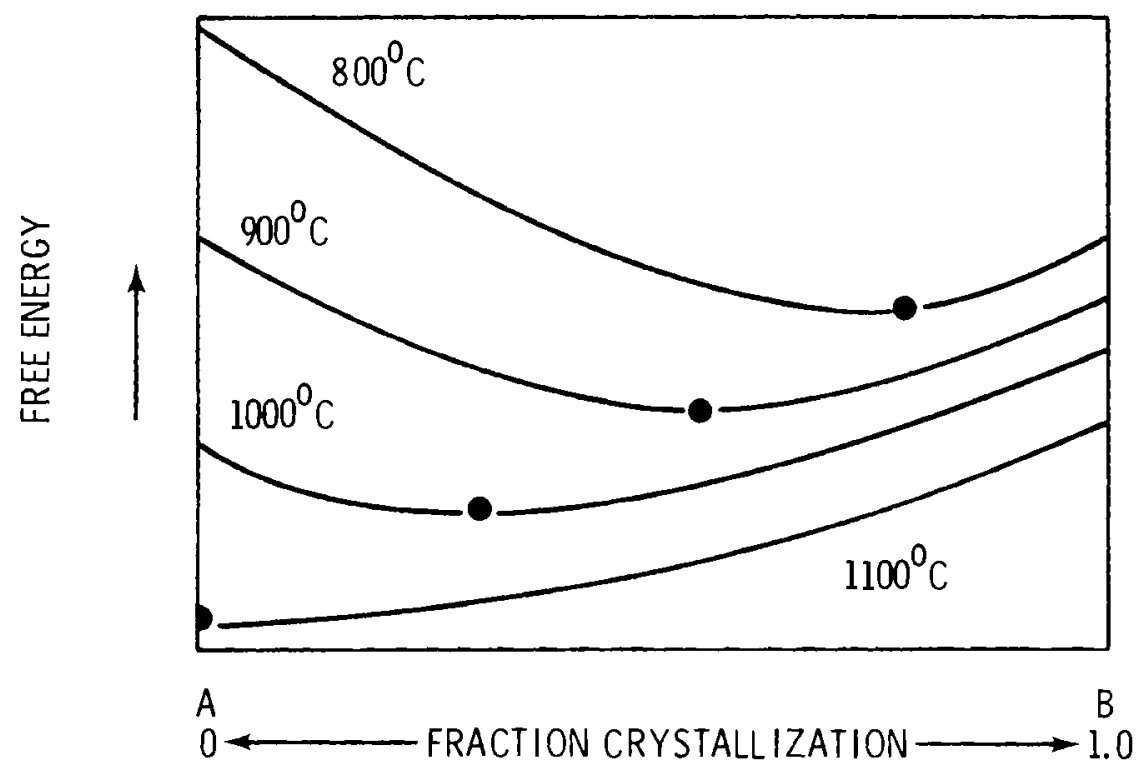

FIGURE B-1. Free Energy Versus Composition as a Function of Temperature

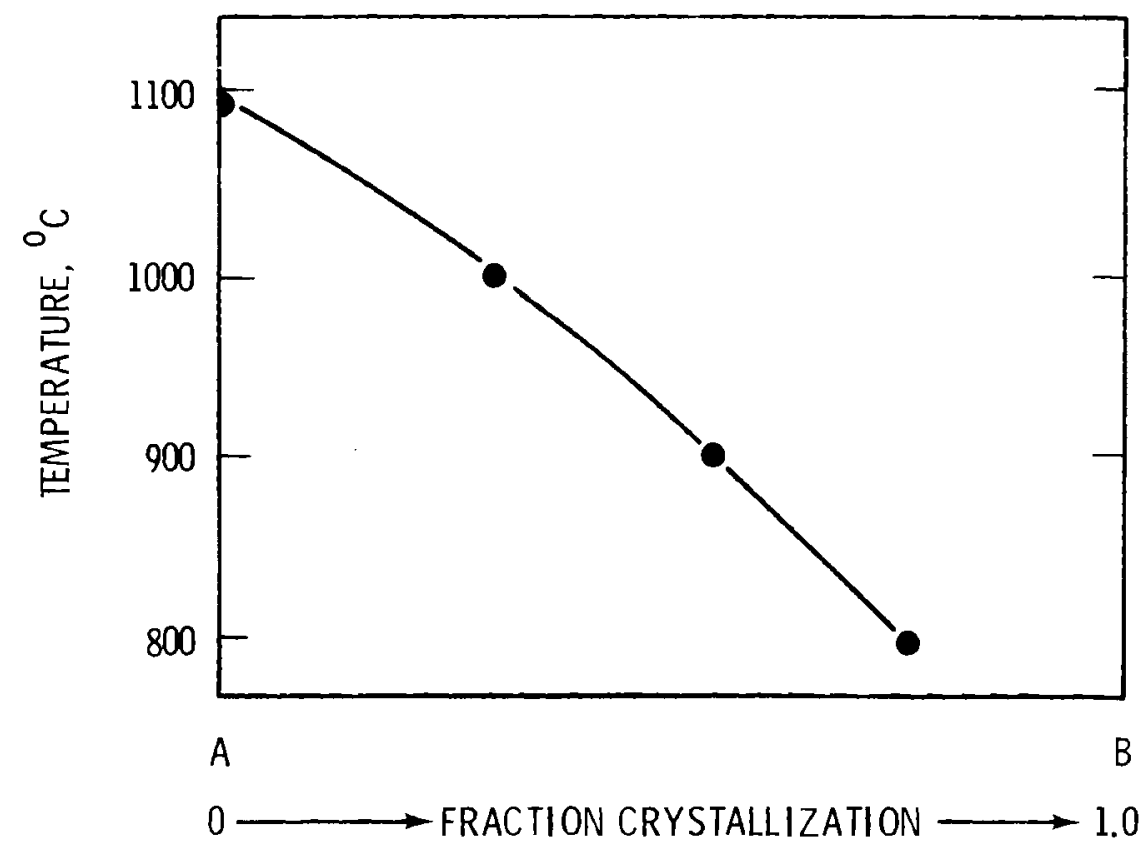

FIGURE B-2. Temperature Versus Fractional Crystallization 
Taking the temperature derivative of (1)

$$
d\left(\frac{\Delta G^{\circ}}{T}\right) / d T=-\frac{\Delta H^{\circ}}{T^{2}}
$$

and with substitution of. Equation (2), the so-called van't Hoff equation is obtained:

$$
\frac{d(R \ln K)}{d(T / T)}=\Delta H^{\circ}
$$

Through this expression, the heat of crystallization can be estimated by measuring the change in the equilibrium constant with temperature. While complex species are actually involved in the present case, we consider approximate descriptions of formation of $\mathrm{Zn}_{2} \mathrm{SiO}_{4}$ and $\mathrm{SrMoO}_{4}$ as examples. The first reaction is

$$
2[\mathrm{ZnO}]_{\text {glass }}+\left[\mathrm{SiO}_{2}\right]_{\text {glass }} \rightarrow \mathrm{Zn}_{2} \mathrm{SiO}_{4} \downarrow
$$

Since the activity of $\mathrm{Zn}_{2} \mathrm{SiO}_{4}$ is $a=1$ and $a_{\mathrm{SiO}_{2}}$ (glass) wconstant

$$
K \propto 1 /[Z n 0]^{2} \text { glass }
$$

Hence

$$
\frac{d\left[\ln \left(1 /[Z n 0]^{2} \text { glass }\right)\right]}{d(1 / T)}=\frac{-\Delta H^{\circ}}{R}
$$

A plot of fractional Zn concentration in the glass phase $\left(f_{Z n}\right)$ as $\ln f_{Z n}$ versus $1 / T$ should give a straight line of slope $+\Delta H^{\circ} / 2 R$.

For the molybdate phase, a simplified reaction is

$$
[\mathrm{SrO}]_{\text {glass }}+\left[\mathrm{MoO}_{3}\right]_{\text {glass }}+\mathrm{SrMoO}_{4} \downarrow
$$


where

$$
\mathrm{K} \propto 1 /\left[\mathrm{SrO}_{\text {glass }}\left[\mathrm{MoO}_{3}\right]_{\mathrm{glass}}\right.
$$

A plot of fractional glass phase concentration as $\ln \left(f_{S r} f_{M o}\right)$ versus $1 / T$ should have a slope, $\Delta H / R$. Actualiy, $\mathrm{Ca}$ and $\mathrm{Ba}$ also participate in the reaction, and the equilibrium constant is rather complex. Because of the higher molar concentration of alkaline earths; it must be that

$$
\Delta f_{M 0}=2.3 \wedge f A 1 k
$$

Applying this relation to the equilibrium constant and using Equation (4) suggests that a plot of $\ln f_{\text {Mo }}$ versus $1 / T$ should have a slope of $\Delta H / 1.7 R$.

\section{KINETICS}

The kinetic description of chemical processes arises from the at first empirical correlation of reaction rates to a simple exponential form by Arrhenius. In this form,

$$
\text { Rate }=S=A \exp (-E / R T)
$$

where the constant $A$ is known as the frequency factor and $E$ is the activation energy for the process. Taking logarithms,

$$
\ln S=\ln A-\frac{E}{R T}
$$

and a plot of ins versus $1 / T$ should yield a straight line of slope $=-\frac{E}{R}$. If data are plotted at constant fractional completion values (for example, considering times ( $\Delta t)$ at $50 \%$ completion)

$$
\ln \left(\frac{{ }^{C} 1 / 2}{\Delta t}\right)=\ln A-\frac{E}{R T}
$$


or

$$
\ln \Delta t=k+E / R T
$$

and a plot of $\ln \Delta t$ versus $1 / T$ will have a slope $=+E / R$.

The activation energy obtained by application of this simple model only defines the "average" process and cannot be easily related to the actual mechanism(s) involved. It is usual to think of crystal growth in terms of nucleation and growth components, either of which may be rate controlling. In waste glass, phases formed may have a composition not too different from the glass composition $\left(\mathrm{Zn}_{2} \mathrm{SiO}_{4}\right)$, or more usually the composition will be quite different $\left(\mathrm{SrMoO}_{4}\right)$. A theory to adequately cover these variations and other mechanistic questions (e.g., a distribution of activation energies for diffusion) has not been demonstrated. The literature is mainly concentrated on the theory and experimental study of very simple systems, which will not be reviewed here. The following sections consider two approaches which can be used to qualitatively understand some aspects of devitrification.

\section{GENERAL CRYSTALLIZATION THEORY}

The nucleation and growth of crystals in a glass matrix is represented schematically in Figure B-3, where the rates are seen to reach maximum values at certain temperatures. The maximum nucleation temperature is usually about $50^{\circ} \mathrm{C}$ above the transformation temperature. Maximum crystallization rates usually occur within $\sim 100^{\circ} \mathrm{C}$ of the liquidous temperature. The position of the nucleation-rate curve along the temperature axis is determined by the diffusion coefficient for transport across the matrix-crystal interface, by the free energy change for the crystallization, and by surface free energy considerations. The crystal growth curve is mainly a function of ion diffusivity (which is related to glass viscosity) and the free energy change involved. The crystal growth rate in waste glass is of greater importance since the 
glass has numerous nucleation sites, as fabricated. In classical growth studies (e.g., Norton, (1) Swift, (2) and Burnett, ${ }^{(3)}$ ) crystal dimensions are measured as a function of time at various temperatures by optical or scanning electron microscopy. Such studies generate the bell-shaped curve (Figure B-3) which can be understood in terms of a growth mechanism controlled at lower temperatures by diffusion and at high temperatures by a rapid decrease in the driving force of crystallization as the liquidous temperature is approached $(\Delta G=0)$. As seen in the following discussion, the interplay of these contributors does not usually lead to a symmetrical growth curve and, for a given glass system, the free energy of crystallization is the dominant parameter to consider.

Following Kingery ${ }^{(4)}$ the crystal growth rate may be expressed as

$$
u=f v a_{0}[1-\exp (-\Delta \cdot G / R T)]
$$

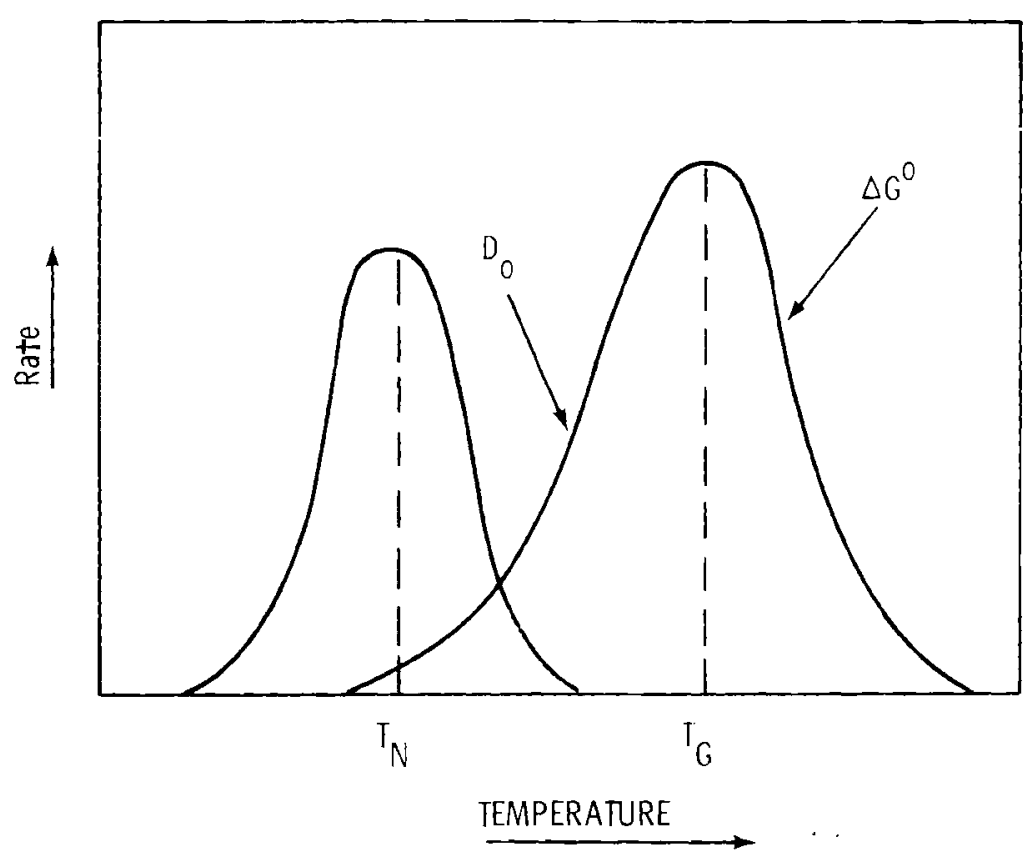

FIGURE B-3. Overall Reaction Rate as a Function of Nucleation $\left(T_{N}\right)$ and Growth $\left(T_{G}\right)$ Temperatures 
where $f$ is related to site availability, $v$ is a frequency factor depending on viscosity, and $\Delta G$ is the energy of crystallization. A form of this equation more useful for calculation is

$$
u=k T\left(T_{\ell}-T\right) \exp \left(\Delta E_{n} / R T\right)[1-\exp (-\Delta G / R T)]
$$

where $T_{\ell}$ is the liquidous temperature, $\Delta E_{n}$ is the activation energy for viscous flow, and $\Delta G$ is the crystallization energy.

Some estimates of these constants are available for the present glass $(72-68)$, as follows:

$$
\begin{aligned}
T_{\ell} & =1248^{\circ} \mathrm{K} \text { (for } \mathrm{Zn}_{2} \mathrm{SiO}_{4} \text { ) } \\
T_{\ell} & =1173^{\circ} \mathrm{K} \text { (for } \mathrm{SrMoO}_{4} \text { ) } \\
\Delta E_{\mathrm{n}} & =62 \mathrm{kcal} / \mathrm{mole} \text { (estimated from data given by Ross) }(5) \\
\Delta G & \sim-13 \mathrm{kcal} / \mathrm{mole}\left(\mathrm{fo}^{\circ} \mathrm{Zn}_{2} \mathrm{SiO}_{4}\right. \text { ) } \\
\Delta G & \sim-53 \mathrm{kcal} / \mathrm{mole} \text { (for } \mathrm{SrMoO}_{4} \text { ) }
\end{aligned}
$$

Figure $B-4$ shows calculated curves assuming $\Delta G$ values as indicated. Note the steep drop in growth rate as the liquidous is approached for the case of low $\Delta G$ values and the shift of maximum growth rate to lower temperatures with increasing $\Delta G$ (i.e. more negative values). Actually, few experimental demonstrations of these curves can be found in the literature. Work by Swift, (2) some 30 years ago, showing an experimental curve (much like the $10 \mathrm{kcal} / \mathrm{mole}$ curve calculated here) is always referenced, and there are no detailed studies of this type directly relevant to nuclear waste glasses. The experimental data points shown were estimated from Section 4 results for $\mathrm{Zn}_{2} \mathrm{SiO}_{4}$. They are clearly in good agreement with the theoretical curve. Figure B-5 considers 


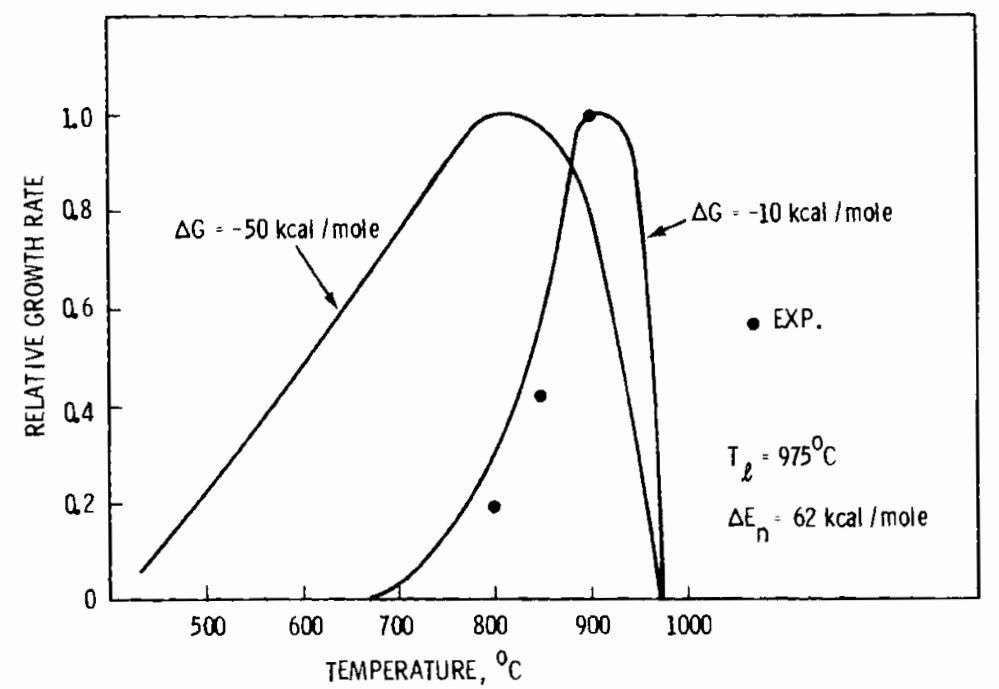

FIGURE B-4. Kinetics of Growth as a Function of Temperature

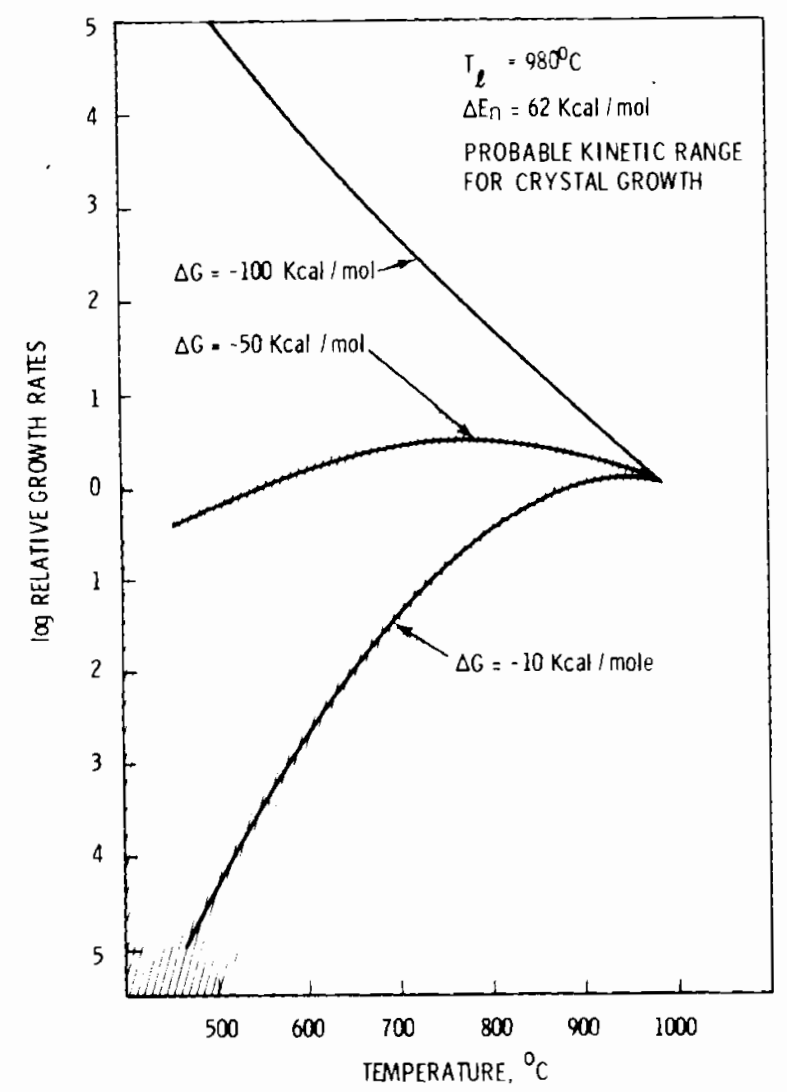

FIGURE B-5. Relative Growth Rate as a Function of Temperature 
calculated curves without normalizing (as done in Figure B-4) plotted as $\log$ (growth rate) versus temperature. The importance of the free energy term is more clear: at $800^{\circ} \mathrm{C}$, the growth rate for $\Delta G=-100 \mathrm{kcal} / \mathrm{mole}$ is more than 2 orders of magnitude greater than for $\Delta G=-10 \mathrm{kcal} / \mathrm{mole}$. For waste glass systems, the present study suggests that behavior will generally fall within the cross-hatched region, with $\Delta G$ in the range 10-60 $\mathrm{kcal} / \mathrm{mole}$, where increasing growth rates with increasing temperaure are observed until near the liquidous temperature.

As clear from Equation 12, both the liquidous temperature for a given phase and the glass viscosity $\left(\Delta E_{n}\right)$ will affect the calculated curves and need to be considered for any values much different than those used here. The general features, however, will not be greatly different as neither the temperature dependence for viscosity nor usual liquidous temperatures will vary greatly, considering present waste vitrification process limitations.

JOHNSON-MEHL-AVRAMI THEORY

After Freeman and Hench ${ }^{(6)}$ the Johnson-Mehl-Avrami (JMA) equation describes the kinetics of processes where nucleation and growth occur simultaneously. This is a reasonable assumption for evaluation of waste glasses. The integrated form is

$$
v_{v}=1-\exp \left[-g I G^{n} t^{n+1}\right]
$$

where

$$
\begin{aligned}
g & \equiv \text { form factor } \\
G & \equiv \text { growth rate } \\
I & \equiv \text { nucleation rate } \\
V_{V} & \equiv \text { volume fraction of new phase } \\
t & \equiv \text { time } \\
n & \equiv \text { an integer depending on growth dimensionality }
\end{aligned}
$$




$$
\begin{aligned}
(n & =3 \rightarrow 3 \text {-dimensional } \\
n & =2 \rightarrow \text { plates } \\
n & =1 \rightarrow \text { rods })
\end{aligned}
$$

Assuming an Arrehnius temperature dependence for both nucleation and growth, Equation 13 becomes

$$
v_{v}=1-\exp \left[-g t^{n+1} I_{0} e^{-E_{I} / R T}\left(G_{0} e^{-E_{G} / R T}\right) n\right]
$$

At constant fractional ingrowth, and taking logarithms,

$$
\ln t_{v}=\left(\frac{1}{n+T}\right)\left[\frac{1}{R T}\left(E_{I}+n E_{G}\right)\right]-\left(\frac{1}{(n+1)}\right)\left[\frac{\ln G_{0}{ }^{n} I_{0} g}{\ln \left(1-V_{v}\right)}\right]
$$

The right hand term is a constant so that a plot of in $t_{v}$ versus $1 / T$ should be a straight line of slope $=\left(\frac{1}{R}\right)\left(\frac{1}{n+1}\right)\left(E_{I}+n E_{G}\right)$ or for $n=3$,

$$
\text { slope }=\frac{1}{4 R}\left(E_{I}+3 E_{g}\right)
$$

Unless some other information is known, or a reasonable assumption is made regarding $E_{I}$ or $E_{G}$, this treatment does not yield any further understanding of the energetics. For the purposes of understanding behavior in waste glasses, the conclusion (Equation 16) at least suggests that experimental measurements of activation energy will be dominated by growth energetics rather than nucleation, provided $E_{G} \gtrsim E_{I}$. 


\section{REFERENCES - APPENDIX B}

1. F. H. Norton, J. Amer. Cer. Soc, 20,217 (1937)

2. H. R. Swift, J. Am. Cer. Soc, 30, 165 (1947)

3. D. G. Burnett and R. W. Douglas, Phys. and Chem. of Glasses, 12,117 (1971).

4. W. D. Kingerey, H. K. Bowman, and D. R. UhImann, Introduction to Ceramics, John Wiley and Sons, New York, Chapter 8, 1976.

5. W. A. Ross, Quarterly Report, Waste Fixation Program. BNWL-1841, Battelle, Pacific Northwest Laboratories, Richland, WA 99352, p. 31, JuTy, 1974.

6. S. W. Freeman and L. L. Hench, J. Amer. Cer. Soc, 51,382 (1968). 
APPENDIX C

QUANTITATIVE ANALYSES 
APPENDIX C

\section{QUANTITATIVE ANALYSES}

\section{X-RAY DIFFRACTION}

Although quantitative analysis by $x$-ray diffraction methods is a wellestablished technique, analysis of partially crystallized waste glasses presents some difficulties more easily accounted for in simple systems. As this is the first thorough study of this kind in very complex glasses, this section outlines procedures followed and provides an assessment of the accuracy that can be achieved. The major problems that must be considered include:

1) x-ray absorption effects

a) by the crystalline species

b) by the glass matrix

2) homogeneity

3) overlapping diffraction peaks

4) nonstoichiometry

Of these potential problems, only point (4) has not been corrected for in the present work, although the corrections can be made either theoretically (i.e., by calculation of the intensities based on actual solid solution compositions) or experimentaliy (by preparation of the substituted compounds for use as standards). The results given in the text for the fluorite phase ( $\left.\mathrm{Ce}, \mathrm{Zn}, \mathrm{RE}^{3+}\right) 0_{2-x}$ and the molybdate $(\mathrm{Ca}, \underline{\mathrm{Sr}}, \mathrm{Ba}) \mathrm{MoO}_{4}$ are reported therefore, as $\mathrm{CeO}_{2}$ and $\mathrm{SrMoO}_{4}$. As the average atomic number (diffraction intensity $\alpha z^{2}$ ) is actually very close to the standard used in both cases, the error introduced is small $(<5 \%)$.

The absorption and homogeneity problems can be minimized by appropriate mechanical milling and identical treatment of standards and samples to be analyzed. In the present work, this included a coarse crush to -70 mesh $(210 \mu \mathrm{m})$, ball milling in a miniature ball mill 
(tungsten carbide and glass) for a minimum of two hours, and a final sieve to -325 mesh $(44 \mu \mathrm{m})$. Particle size distributions were determined on vitreous 73- 1 and 72-68 samples, which had undergone this procedure as illustrated in Figures $\mathrm{C}-1$ and $\mathrm{C}-2$, respectively. The mean particle size was found to be approximately $10 \mu \mathrm{m}$ for glass 73-1 and $5 \mu \mathrm{m}$ for glass $72-68$ with $75 \%$ of the total volume in both cases being less than $20 \mathrm{~mm}$. Differences in particle size between the two glasses might be attributed to the differences in micro-strains present in the glass systems as a result of insolubles or devitrification products present. The higher inherent microstrains and refractory oxides present in the 72-68 glass may aid the grinding process.

Klug and Alexander ${ }^{(1)}$ have presented data relating average crystalline size and the measurement of diffracted intensity. For a given peak in a single-component system such as quartz, they reported that the integrated intensity would increase as mean particle size decreases to a size fraction of 5-15 $\mu \mathrm{m}$, below which the integrated intensity remained fairly constant. For a multi-component system such as glass 72-68 it is expected that the measurement of integrated intensity will follow this behavior

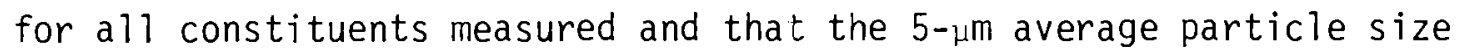
measured in 72-68 is adequate to produce consistant integrated area measurements.

Homogeneity was checked by $x$-ray fluorescence mapping of standards prepared in the above fashion using pure compounds and the vitreous glass. Some agglomeration of the "dopant" phase occurred for $\mathrm{RuO}_{2}$ (which was not used as a standard). For the $\mathrm{Zn}_{2} \mathrm{SiO}_{4}, \mathrm{SrMoO}_{4}$, and $\mathrm{CeO}_{2}$ standards, there was no indication of mixing problems. For devitrified glasses, all but a few metallographic samples demonstrated a uniform crystal distribution before ball milling, so that homogeneity problems should not have occurred.

In choosing diffraction peaks to evaluate, care was taken to avoid overlapping or closely adjacent reflections from different phases, as far as practical. As a result, the region of scan from approximately 


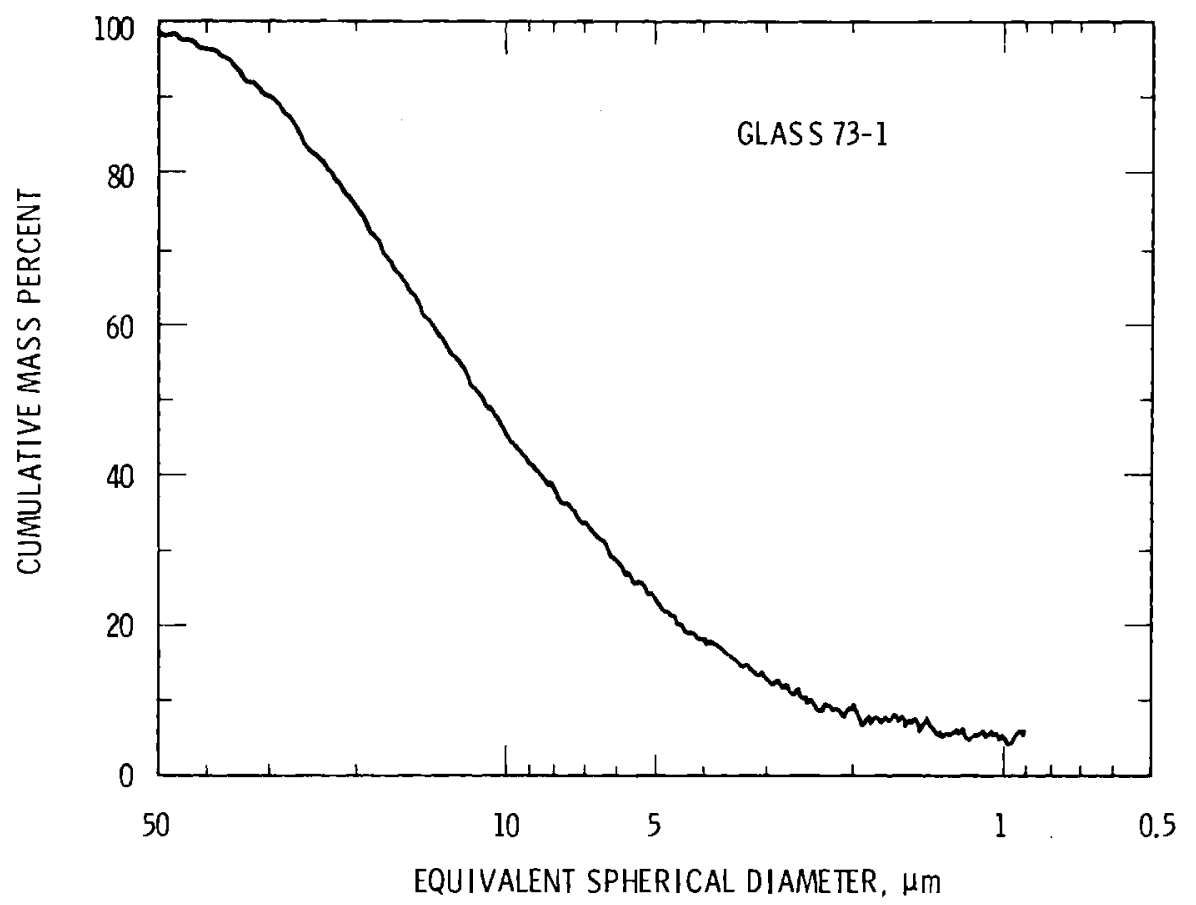

FIGURE C-1. Equivalent Spherical Diameter for 73-1 Glass Powder

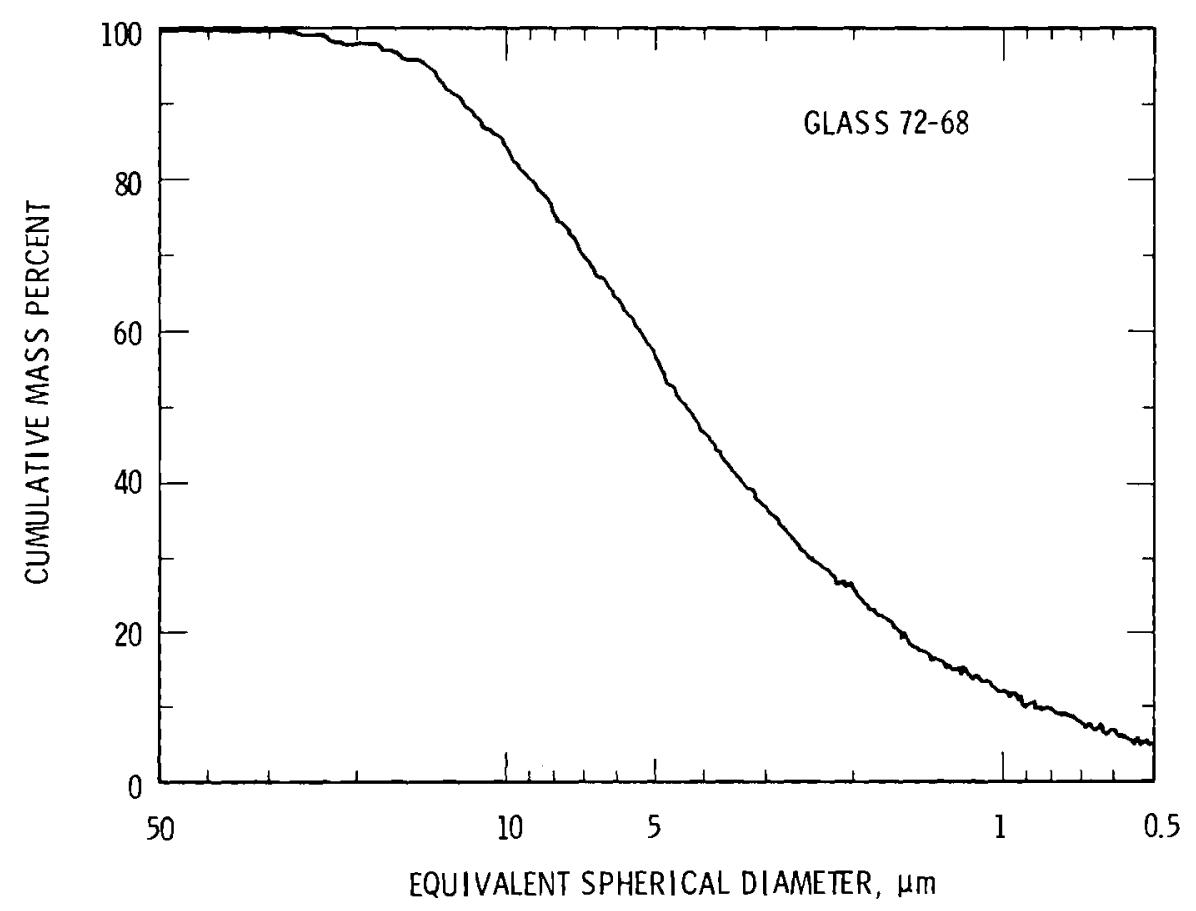

FIGURE C-2. Equivalent Spherical Diameter for 72-68 Glass Powder 
26 to $32^{\circ}(2 \theta)$ was chosen since it incluaed a 71 the crysta 71 ine phases with reasonably strong peaks and at tolerable resolution. Slow scans $\left[1 / 8^{\circ}(2 \theta)\right.$ per minute] were always run since they provided maximum integrated intensity at the highest attainable resolution. In the evaluation of diffraction intensities the integrated intensity rather than maximum intensity was measured, since in the real glass system large variations in line shape can occur because of variations in composition and/or microstrain. Peak areas were determined by tracing the peak above the background on high-quality tracing paper (Keuffel and Esser \#12-5465), cutting and weighing. Peak weights were converted by means of a constant conversion factor to total integrated counts, which were plotted in turn against the known weight percentages of crystalline species in the mixture. The good agreement between measurement based on Zn depletion, using microprobe analysis, and $\mathrm{Zn}_{2} \mathrm{SiO}_{4}$ concentration, using the $x$-ray method (see Figure 7), is a strong indiciation of an adequate experimental technique.

Figures $\mathrm{C}-3, \mathrm{C}-4$, and $\mathrm{C}-5$ show the standard curves generated for $\mathrm{Zn}_{2} \mathrm{SiO}_{4}$, $\mathrm{SrMOO}_{4}$, and $\mathrm{CeO}_{2}$, in that order. The error bars indicated represent $1 \sigma$ standard deviations from five separate determinations of each point, taken over a two-week period. It is noteworthy that deviations from a simple linear relation between intensity and concentration are important. Table C-l lists standard \% error as a function of weight percent. The average absolute error over the full range was $\pm 0.33 \mathrm{wt} \%$, representing the sum of a 11 random experimental and data reduction errors. It can be concluded that concentration determinations of crystalline phases down to the $0.5-w t \%$ level will usually be possible in waste glass systems. It is interesting to note as described later, that present experience with routine application of the microprobe/x-ray fluorescence technique also gives limits for quantitative analysis of $\sim \pm 0.3 \mathrm{wt} \%$, although sensitivity for qualitative work is much higher. 


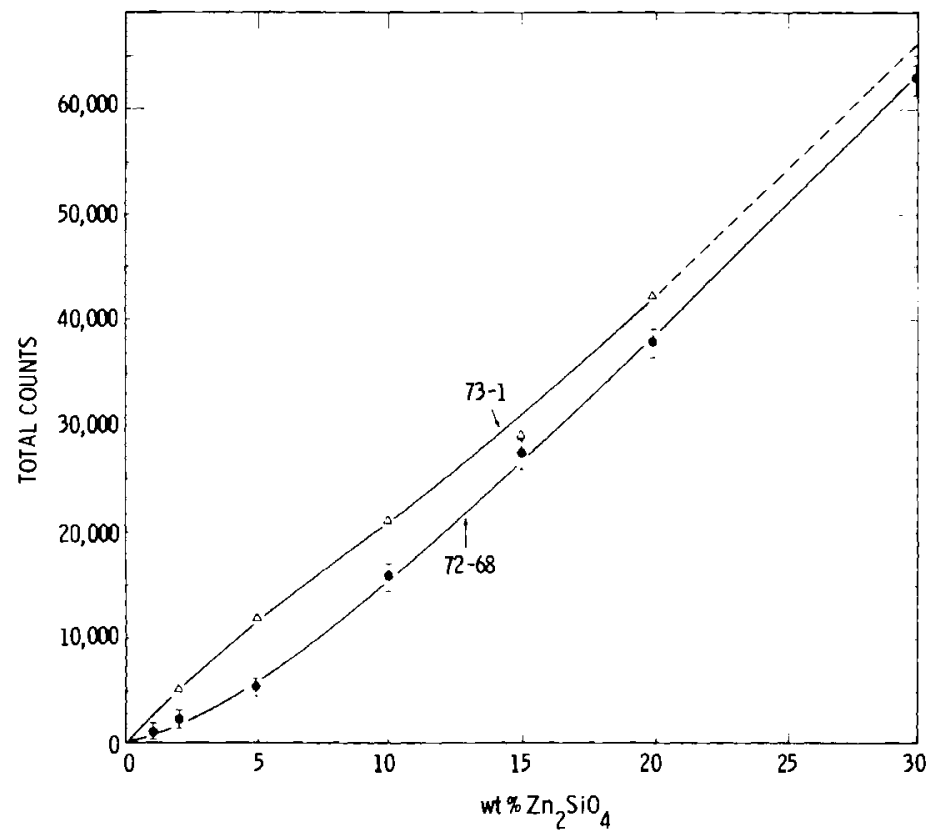

FIGURE C-3. Integrated X-Ray Intensity Versus weight Percent $\mathrm{Zn}_{2} \mathrm{SiO}_{4}$ in Vitreous Waste Glass

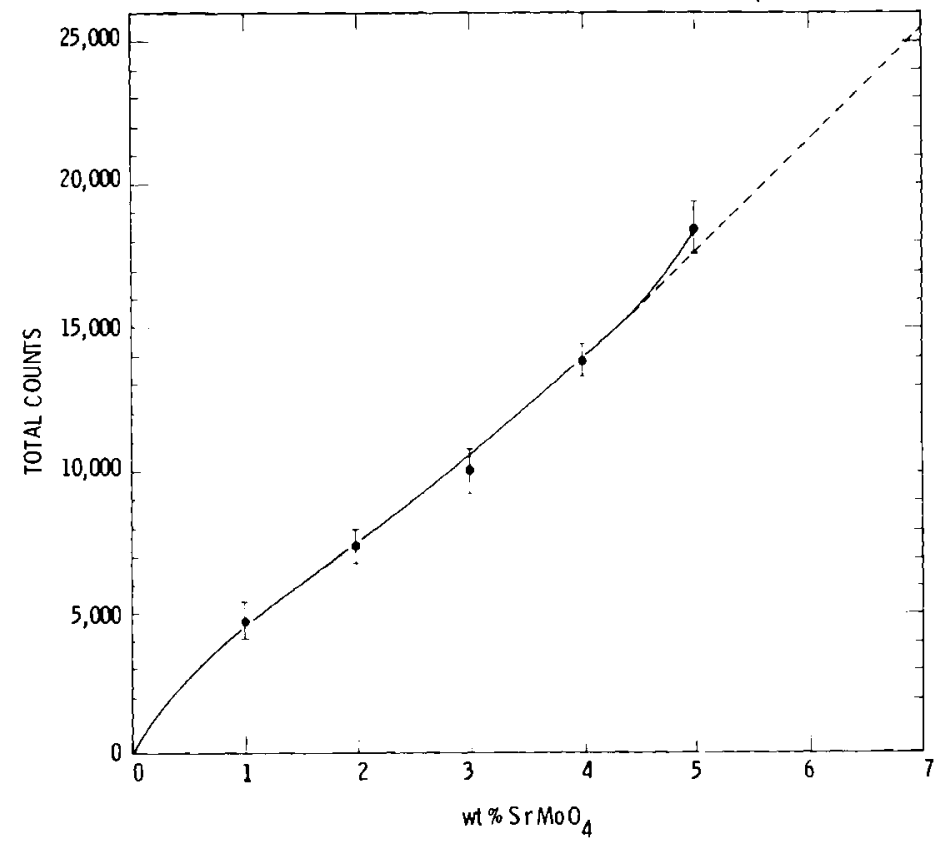

FIGURE C-4. Integrated X-Ray Intensity Versus Weight Percent $\mathrm{SrMoO}_{4}$ in Vitreous Waste Glass 


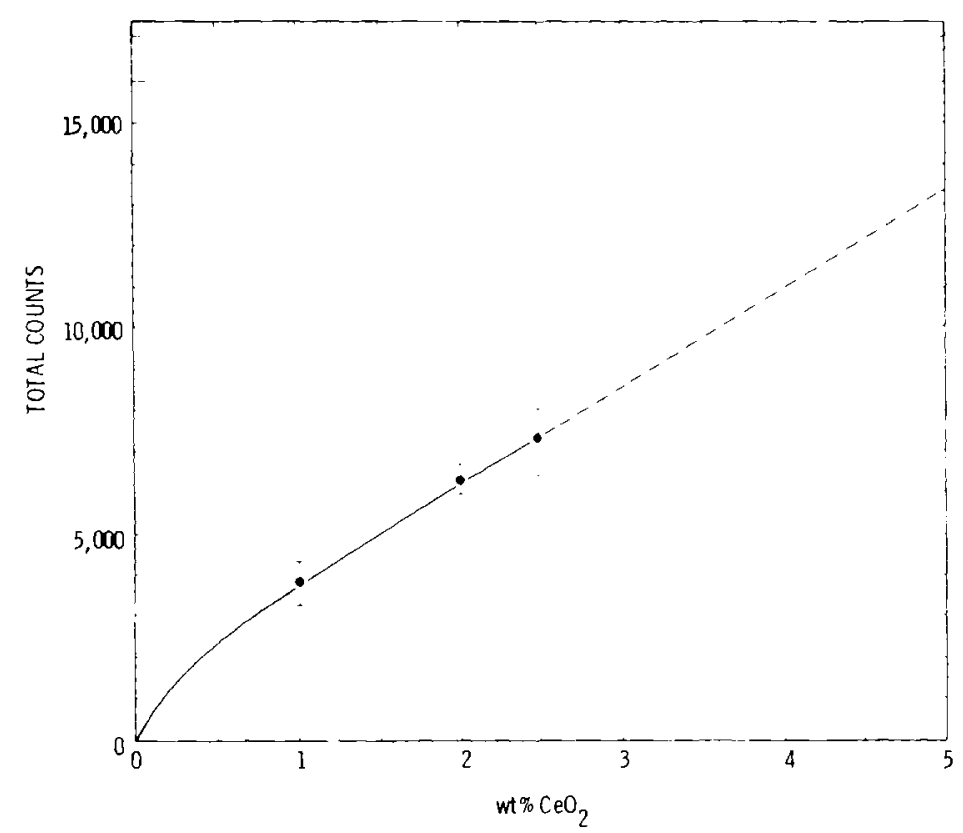

FIGURE $\mathrm{C}-5$. Integrated $\mathrm{X}$-Ray Intensity Versus Weight Percent $\mathrm{CeO}_{2}$ in Vitreous Waste Giass

TABLE $\mathrm{C}-1$. Percent Deviation in Measurement as a Function of Weight Percent for the Three Crystalline Materials Used for the Standard Curve Determination

Material

Weight Percent

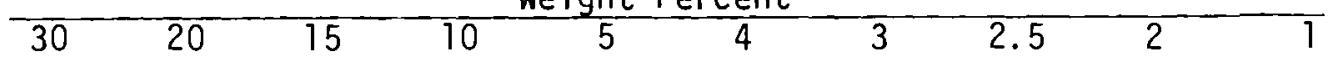

\begin{tabular}{|c|c|c|c|c|c|c|c|c|c|c|}
\hline $\mathrm{Zn}_{2} \mathrm{SiO}_{4}$ & \pm 1.65 & \pm 2.80 & \pm 4.99 & \pm 7.07 & \pm 12.68 & & & & \pm 5.15 & \pm 20.42 \\
\hline $\mathrm{SrMoO}_{4}$ & -- & - & -- & - & \pm 5.10 & \pm 4.37 & \pm 8.25 & & \pm 8.20 & \pm 15.06 \\
\hline $\mathrm{CeO}_{2}$ & -- & -- & -- & - & -- & - & -- & \pm 9.75 & \pm 5.03 & \pm 14.44 \\
\hline
\end{tabular}




\section{ELECTRON MICROSCOPE/MICROPROBE ANALYSES}

Elemental concentrations were measured in vitreous glass (72-68) samples using three different instruments and operators. As shown in Table $\mathrm{C}-2$, the results were similar for determinations of the same element. The work done on the SEM instruments involved the use of a much better reference standard, the fission-product-free glass frit (73-1), than was used for the microprobe determinations. Other experience has shown that the microprobe gives better quantitative data than is easily obtained on the SEM instruments. Part of the reason for this is the better resolution of the wave length dispersive detection system on the microprobe and better counting statistics compared to energy dispersive analysis on the SEM instruments. A second contribution is historical: microprobe systems are usually used for quantitative analyses whereas the SEM systems (and the operator) are usually applied in microstructural studies and more qualitative elemental analyses. Nevertheless, Table $\mathrm{C}-2$ shows generally acceptable results in all cases. Because of the microstructural complexity of devitrified waste glasses, the authors believe an SEM instrument with energy dispersive fluorescence analysis is the more desirable instrument for studies of this nature.

\section{TABLE C-2. Fluorescence Analyses}

\begin{tabular}{|c|c|c|c|c|c|}
\hline & El ement & $\begin{array}{c}\text { Nomina } 1 \\
\text { wt: }\end{array}$ & Probe ${ }^{(a)}$ & SEM $(b)$ & $\operatorname{SEM}^{(b)}$ \\
\hline \multirow[t]{8}{*}{ Vitreous Glass 72-68 } & $\mathrm{Mq}$ & 0.9 & 1.0 & - & -- \\
\hline & $\mathrm{Ca}$ & 1.1 & 1.0 & 1.1 & 1.0 \\
\hline & $S r$ & 1.8 & 2.0 & 2.2 & 2.0 \\
\hline & $\mathrm{Ba}$ & 2.2 & 1.8 & 1.5 & $\cdots$ \\
\hline & $\mathrm{Na}$ & 3.0 & 3.8 & 2.8 & -- \\
\hline & K & 3.4 & 3.6 & 3.6 & 3.4 \\
\hline & $\mathrm{Si}$ & 12.7 & 16.9 & 13.6 & 9.0 \\
\hline & $\mathrm{Zn}$ & 17.1 & 16.9 & 17.6 & 15.8 \\
\hline \multirow[t]{3}{*}{$\begin{array}{l}\mathrm{Zn}_{2} \mathrm{SiO}_{4} \text { Crystals } \\
\text { in Glass } 72-68\end{array}$} & & & & & \\
\hline & Si & 12.6 & 12.7 & 10.7 & 7.7 \\
\hline & $\mathrm{Zn}$ & 58.7 & 44.9 & 58.5 & 43.4 \\
\hline
\end{tabular}




\section{REFERENCES - APPENDIX C}

1. H. P. Klug and L. E. Alexander, X-Ray Diffraction Procedures. John Wiley and Sons, Inc., New York, 1967. 


\section{DISTRIBUTION}

No. of

No. of

Copies

Copies

OFFSITE

UNITED STATES

A. A. Churm

DOE Chicago Patent Group

9800 South Cass Avenue

Argonne, IL 60439

S. H. Smiley

Deputy Director for Fuels and Materials

NRC Directorate of Licensing

for Fuels and Materials

4915 St. Elmo Ave.

Bethesda, MD 20014

W. P. Bishop

Chief, Waste Management Branch

NRC Division of Materials and

Fuel Cycle Facility Licensing Washington, DC 20555

W. G. Belter

DOE Division of Biomedical and Environmental Research

Earth Sciences Branch

Washington, DC 20545

\section{W. A. Brobst}

DOE Division of Environmental

Control Technology

Washington, DC 20545

W. E. Mott

DOE Division of Environmental Control Technology

Washington, DC 20545
G. W. Cunningham

Director, DOE Division of Waste

Management, Production and

Reprocessing

Washington, DC 20545

R. B. Chitwood

DOE Division of Waste Management Production and Reprocessing

Washington, DC 20545

C. A. Heath

DOE Division of Waste Management Production and Reprocessing Washington, DC 20545

G. Oertel

DOE Division of Waste Management

Production and Reprocessing Washington, DC 20545

J. M. Taub

DOE Division of Waste Management

Production and Reprocessing

Washington, DC 20545

R. D. Walton

DOE Division of Waste Management

Production and Reprocessing

Washington, DC 20545

DOE Idaho Operations Office

PO Box 2108

Idaho Falls, ID 83401 
No. of

No. of

Copies

Copies

J. J. Schreiber

Research Library

DOE Oak Ridge Operations Office

PO Box X

Oak Ridge, TN 37830

Battelle Memorial Institute

505 King Ave.

Columbus, $\mathrm{OH} 43201$

267 DOE Technical Information Center

2 Brookhaven National Laboratory

Research Library

Reference Section

A. P. Roeh, Manager

Process Evaluation Branch

Allied Chemical Corp.

550 - 2nd Street

Idaho Fal1s, ID 83401

J. B. Berreth

Allied Chemical Corporation

550 - 2nd Street

Idaho Falls, ID 83401

Allied Chemical Corporation (File Copy)

550 - 2nd Street

Idaho Falls, ID 83401

J. A. Buckham

Allied-General Nuclear Services

PO Box 847

Barnwe11, SC 29812

Information Division

Upton, Long Island, NY 11973

Combustion Division

Combustion Engineering, Inc.

Windsor, CT 06095

2 M. A. Thompson

Rockwell International

Rocky Flats Division

Golden, 'CO 80401

M. D. Boersma

duPont Company, Aiken (DOE)

E. I. duPont DeNemours and Co.

Savannah River Laboratory

Aiken, SC 29801

C. H. Ice

duPont Company, Aiken (DOE)

E. I. duPont DeNemours and Co. Savannah River Laboratory

A. Williams

Allied-General Nuclear Services

P0 Box 847

Barnwe11, SC 29812

Aiken, SC 29801

A. S. Jennings

duPont Company, Aiken (DOE)

J. L. Jardine

M. J. Steindler/L. E. Trevorrow

E. I. duPont DeNemours and Co.

Savannah River Laboratory

Aiken, SC 29801

9700 South Cass Ave.

Argonne, IL 60439

P. H. Permar

duPont Company, Aiken (DOE)

D. R. Farmeio

Battelle Memorial Institute

505 King Ave.

E. I. duPont DeNemours and Co. Savannah River Laboratory

Columbus, $\mathrm{OH} 43201$ 
No. of

Copies

M. J. Plodinee

duPont Company, Aiken (DOE)

E. I. duPont DeNemours and Co.

Savannah River Laboratory

Aiken, SC 29801

L. Henning

Electric Power Research Institute 3412 Hillview Ave.

P.0. Box 10412

Palo Alto, CA 94304

Environmental Protection Agency

Technology Assessment Div. (AW-559)

Office of Radiation Programs

U.S. Environmental Protection Agency

Washington, DC 20460

R. G. Barnes

General Electric Company

175 Curtner Ave.

(M/C 160)

San Jose, CA 95125

L. H. Brooks

Gulf Energy and Environmental Systems

P.0. Box 81608

San Diego, CA 92138

$2 \quad$ Central Research Library Document Reference Section

Oak Ridge National Laboratory (DOE)

Oak Ridge, TN 37830

3 Los Alamos scientific Laboratory (DOE)

P.0. Box 1663

Los Alamos, NM 87544

C. J. Kershner

Monsanto Research Corporation

Mound Laboratory

P.0. Box 32

Miamisburg, $\mathrm{OH} 45342$
No. of

Copies

John Pomeroy

Technical Secretary

National Academy of Sciences

Committee of Radioactive Waste

Management

National Research Council

2101 Constitution Avenue

Washington, DC 20418

2 J. P. Duckworth

Plant Manager

Nuclear Fuel Services, Inc.

P.0. Box 124

West Valley, NY 14171

J. G. Cline, General Manager

NYS Atomic and Space Development

Authority

230 Park Avenue, Rm. 2425

New York, NY 10017

J. K. Johnstone

Sandia Laboratories

Albuquerque, NM 87107

W. Weart

Division 1140

Sandia Laboratories

Albuquerque, NM 87107

H. D. Sivinski

Sandia Laboratories

A1buquerque, NM 87107

J. 0. Blomeke

Union Carbide Corporation (ORNL)

Chemical Technology Division

P.0. Box $Y$

oak Ridge, TN 37830

2 D. E. Ferguson

Union Carbide Corporation (ORNL)

Chemical Technology Division

P.0. Box Y

Oak Ridge, TN 37830 
No. of

Copies

W. C. McClain

Union Carbide Corporation (ORNL)

Chemical Technology Division

P.0. Box Y

Oak Ridge, TN 37830

7 C. D. Zerby

Union Carbide Corporation

Nuclear Division

Office of Waste Isolation

P.0. Box $Y$

Oak Ridge, TN 37830

R. A. Beal1

U.S. Department of Interior

Bureau of Mines

Albany Research Center

1450 W. Queen Avenue

Albany, OR 97321

S. E. Logan

University of New Mexico

Albuquerque, NM 87131

R. G. Post

College of Engineering

University of Arizona

Tuscon, AZ 85721

Foreign

Rene Amavis

EURATOM

Health Physics Division

29, Rue Aldringer

Luxenbourge, BELGIUM

A. Marples

Atomic Energy Research

Establishment

Harwel1, Didcot,

Berks, ENGLAND

K. D. B. Johnson

Atomic Energy Research

Establishment

Harwe 11, Didcot,

Berks, ENGLAND
No. of

Copies

D. W. Clelland

United Kingdom Atomic Energy Authority

Risley, ENGLAND

P. J. Regnaut

Centre d'Etudes Nucleaires de Fontenay-aux-Roses

Boite Postale 6

92 - Fontenay-aux-Roses

FRANCE

Y. J. Sousselier

Centre d'Etudes Nucleaires de Fontenay-aux-Roses

Boite Postale 6

92 - Fontenay-aux-Roses

FRANCE

Bundesministerium fur Forschung und Technologie

Stressemannstrasse 2

5300 Bonn

GERMANY

Hans W. Levi

Hahn-Meitner-Institut

für Kernforschung Berlin (HMI)

Glienicker Strasse 100

1000 Berlin 39

GERMANY

W. Lutze

Hahn-Meitner-Institut

für Kernforschung Berl in (HMI)

Glienicker Strasse 100

1000 Ber 1 in 39

GERMANY

W. Mueller

Transuranium Institute

Karlsruhe

GERMANY

Center for Atomic Energy

Documentation (ZAED)

Attn: Dr. Mrs. Bell

P.0. Box 3640

7500 Karlsruhe

GERMANY 
No. of

Copies

H. Krause ..
Gesellschaft fur
Kernforschung (GfK)
Postfach 3640
D7500 Karlsruhe
GERMANY
Ferruccio Gera
CNEN - C.S.N Casaccia
Laboratorio Rifiuti Radioacttivi
Casel la Postale 2400
O0100 Roma, ITALY
N. S. Sunder Rajan
Bhabha Atomic Research Center
Waste Treatment Division
Trombay, Bombay, 400 085 INDIA

R. V. Amalraj

C.W.M.F. Project

P.O. Kalpakkam

Chingleput Dist.

Tami1 Nadu, INDIA

2 International Atomic Energy Agency

Kärtner Ring 11

P.0. Box 590

A-11011, Vienna, AUSTRIA

M. Toml inson

Director of Chemistry and Materials Science Division

Atomic Energy of Canada Ltd.

Whiteshell Nuclear Research Establishment

Pinawa, Manitoba, CANADA

ONSITE - RICHLAND, WA 99352

5 DOE Richland Operations Office

R. B. Goranson

M. J. Shupe

D. J. Squires

M. J. Zamorski

H. E. Ransom
No. of

Copies

11 Rockwell Hanford Operations
H. Babad
L. C. Chick
R. A. Deju
R. J. Gimera
E. J. Kosiancic
M. J. Kupfer
C. M. Manry
J. H. Roecker
D. M. Strachen
D. D. Widrich
File Copy

\section{Exxon}

S. J. Beard

2 Joint Center for Graduate Study '

J. Cooper

L. C. Olsen

2 United Nuclear Industries, Inc.

T. E. Dabrowski

A. E. Engler

Westinghouse Hanford Company

A. G. Blasewitz

59 Battelle-Northwest

J. W. Bartlett

W. J. Bjorklund

H. T. Blair

W. F. Bonner

D. J. Bradley

J. L. Buelt

L. R. Bunnel 1

C. C. Chapman

T. D. Chikalla

A. A. Garrett

E. R. Irish

J. H. Jarrett 
Y. B. Katayama

D. E. Larson

J. M. Lukacs

R. P. Marsha 11

J. L. McElroy

G. B. Mellinger

J. E. Mendel

W. J. Mikols

R. E. Nightingale

D. E. Olesen

A. M. Platt

D. L. Prezbindowski

F. P. Roberts

W. A. Ross

J. M. Rusin

D. H. Siemens

R. P. Turcotte (10)

J. W. Wald (10)

W. J. Weber

H. H. Van Tuy 1

J. H. Westsik, Jr.

L. D. Williams

Technical Information (5)

Technical Publications

M.C.Dunn 